\title{
نظرة منيفة
}

إلى المكانة|الحديثية

لإلإمام الأعظم أبي حنيفة

دأحمد رجب أحمل عدوي

ملدرس الحديث الشريف وعلومها

بكلية أصول الدين والد عوة الإسلامية بطنطا

جامعةالأزهر الثريف 


\section{نظرة منيفة إلى المكانة الحديثية للإمام الأعظم أبي حنيفة}

\section{نظرة منيفة إلى المكانة الحديثية للإمام الأعظم أبي حنيفة}

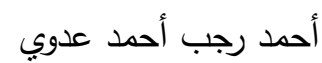

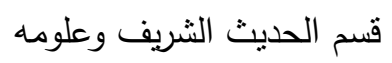

بكلية أصول الدين والدعوة الإسلامية بطنطا

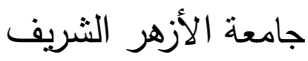

\section{Ahmedadawi.2027@azhar.edu.eg}

\section{ملخص البحث}

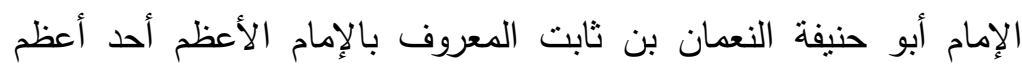

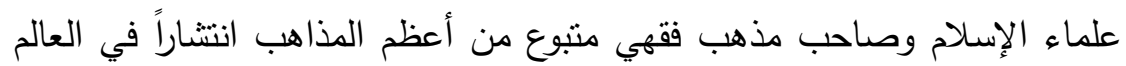

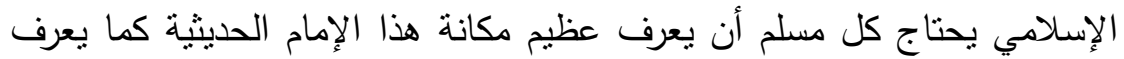
منزلته الفقهية،

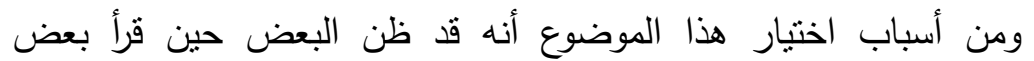

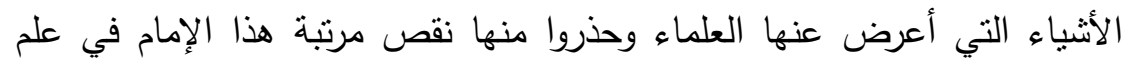

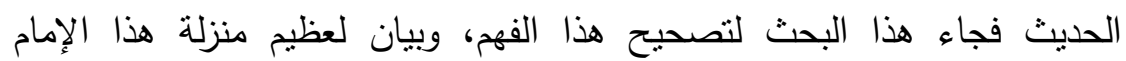
الحديثية، وهو مشتمل على مقدمة متضمنة أسباب اختيار الموضوع وأهمان لهميته وجاء الفصل الأول وهو بعنوان (تعريف عام بالإمام أبي حنيفة) متتاولاً تحقيق اسمه ونسبه ونوع الولاء، ومولده كل ذلك ليعلم طبقة الإمام واتصال أسانيده من عدمها

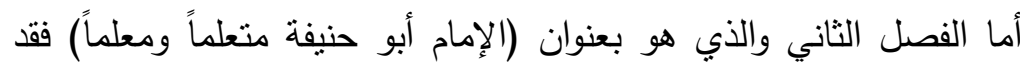

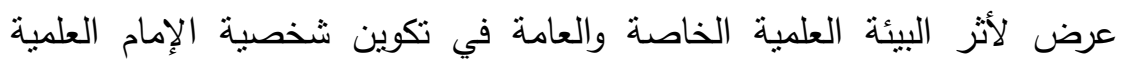
ونبوغه، وأثنبت هذا الفصل كون الإمام رضي الله عنه تابعياً، وبين كثرة رحلات

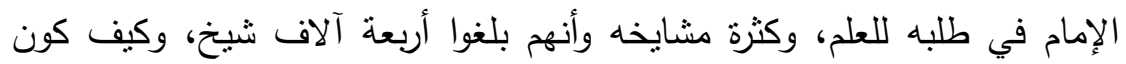

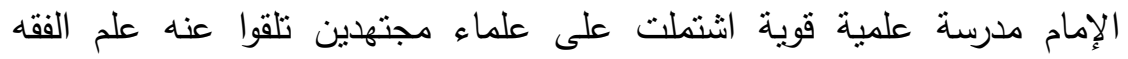
والحديث، وكيف كان يعلمه ويدارسهم بمنهج بديع فريد كل ذللك مما يؤيد مزيد

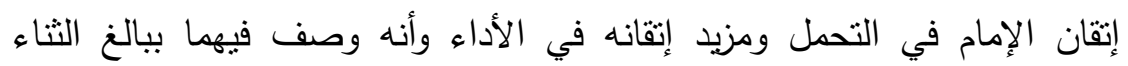
والمدح

ثم جاء الفصل الثالث الذي يعتبر لب الموضوع والبحث وهو بعنوان (بيان منزلة الإمام في علم الحديث من خلاء ثناء العلماء عليه) وقد قسمته لخمسة بحوث أولها أنه وصف بأعلى درجات التعديل وقد جاء ذللك عن أكثر من ثناثين 
من العلماء والحفاظ بأسانيد الكثير منها صحيح أو حسن، أو متعدد الطرق

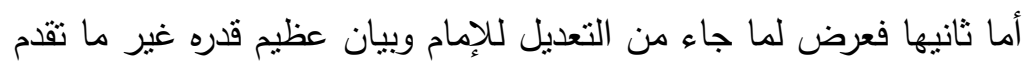

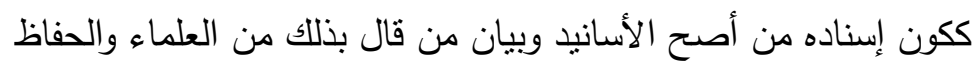

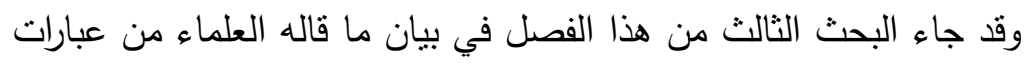

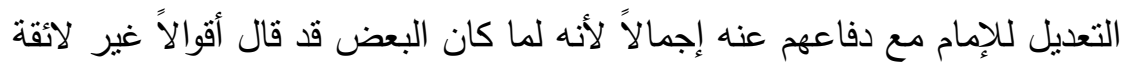

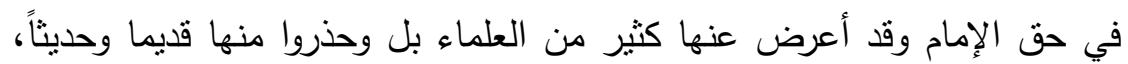
توجب الإشارة إلى ذلك وبيان بعض الإم الأسباب الداعية إليه

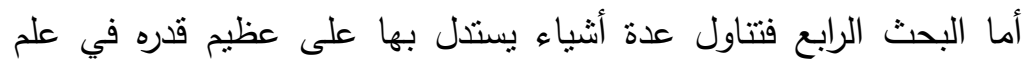
الحديث والبحث الخامس كان لبيان كثرة حديث الإمام وأنه ليس بقليل الحديث وأن

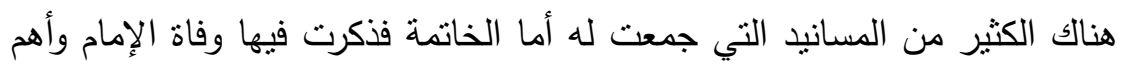
الدراسات السابقة: أُلفت العديد من الكتب في مناقب الإمام الأعظم أبي

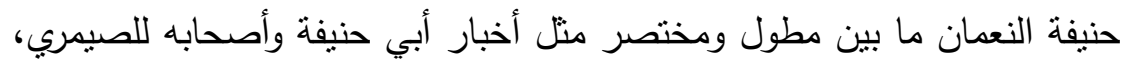

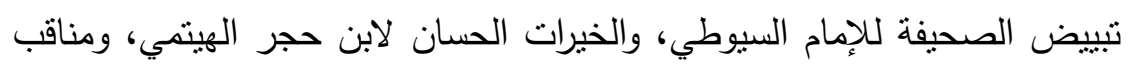

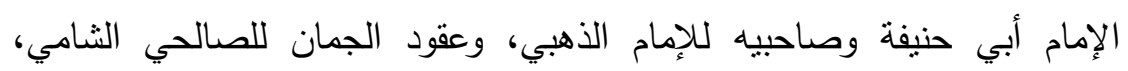

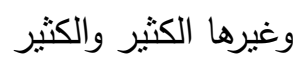

لكن لم أر من خصص بحثاً لبيان منزلة الإمام الحديثية إلا بحثاً لفضيلة

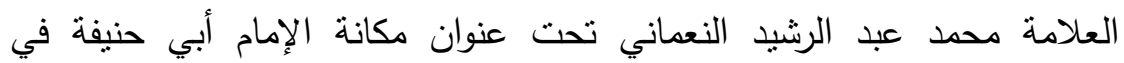
الحديث وهو مذكور في مراجع هذا البحث لم يقسم إلى فصول وأبواب وإنما نقاط العيد

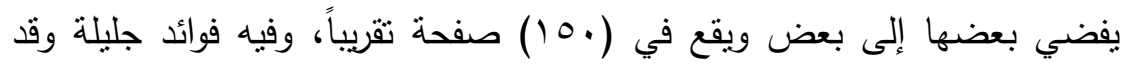

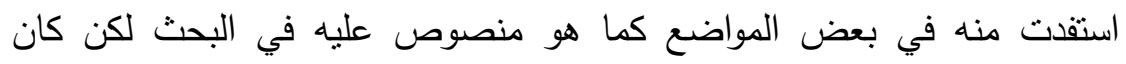

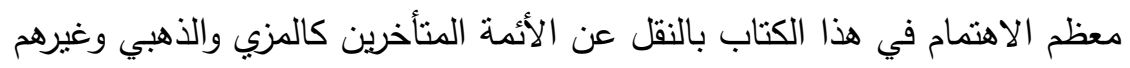

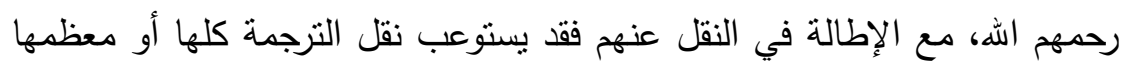

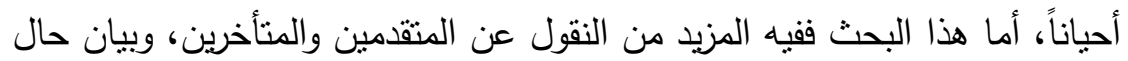

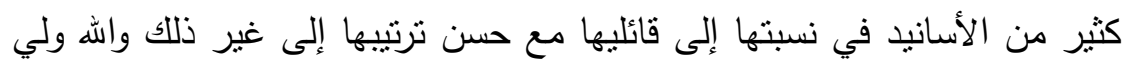
التوفيق الكلمات المفتاحية: أبو حنيفة - الأعظم - مكانة- حيثية - منيفة 
نظرة منيفة إلى المكانة الحليثية للإمام الأعظم أبي حنيفة

\title{
Blissful view of the Hadithi status of the Great Imam \\ "Abu Hanifa" \\ Ahmed Ragab Ahmed Adawi \\ Department of Hadith and its Sciences \\ Faculty of Fundamentals of Religion and Islamic \\ Da'wa in Tanta \\ Al-Azhar University
}

Ahmedadawi.2027@azhar.edu.eg

\begin{abstract}
Imam Abu Hanifa al-Nu'man bin Thabit, known as the Great Imam, one of the greatest scholars of Islam and the founder of Hanafi school of Sunni jurisprudence, which has remained the most widely practiced law school in the Sunni tradition in the Islamic world. Every Muslim needs to know the great Hadithi status of this Imam as he is known for his jurisprudence status.
\end{abstract}

One of the reasons for choosing this topic is that some people thought that, when they read some of the things that scholars avoided and warned about, the imam's status in Hadith science is low so this research has been introduced to correct this misunderstanding, and to demonstrate the great Hadithi status of this Imam. This research includes an introduction states the reasons for choosing this topic and its importance.

The first chapter, entitled (General Definition of Imam Abu Hanifa), provides the identification of his name, lineage, type of amity, and his birth in order to indicate the imam's generation class "Sunni branch of Islam" and whether its chain of transmission was connected or not.

The second chapter, entitled (Imam Abu Hanifa as educated and educater), addressed the effect of the private and public scientific environment on the formation and genius of the scientific characteristic of Imam Abu Hanifa. This chapter demonstrated that Imam Abu Hanifa, may Allāh be pleased with him, was a follower "Tābi" (the generation of Muslims who followed the Companions of the Prophet Muhammad "ṣahābah"), and indicated the large number of trips conducted by Imam Abu Hanifa for seeking knowledge. This chapter proved the abundance of its sheikhs as they reached four 
thousand sheikhs, how Imam Abu Hanifa formed a strong scientific school that included hardworking scholars who received knowledge of jurisprudence and Hadith, and how he taught and lecture them with a unique and creative approach. These all stand as an evidence of the greater mastery of endurance and performance of Imam Abu Hanifa, and his description as highly commendable and praising.

Then, the third chapter, which is considered the core of the topic and research, which is entitled (Explaining the position of Imam Abu Hanifa in the science of Hadith through the praise of scholars on him). The third chapter has been divided into five theses, the first of which is that Imam Abu Hanifa was described the highest degrees of modification by more than thirty scholars and he preserved the chains of transmission of many of them, some of which are sound, good, or multi-chains. The second of which not only demonstrated the great status of Imam Abu Hanifa but also showed that his chain of transmission is the most authentic chains of transmission and those who said so from the scholars and traditionists.

The third thesis of this chapter explained the terms of the modification stated by the scholars on defending Imam Abu Hanifa. Because when some had said inappropriate sayings regarding Imam Abu Hanifa, and many ancient and modern scholars not only have avoided them but also warned against them, it is necessary to indicate this topic and clarify some reasons therefor.

The fourth thesis addressed several things indicate that Imam Abu Hanifa has a great status in the science of Hadith.

The fifth thesis demonstrated the large number of Imam Abu Hanifa's hadith and that there are many chains of transmission were collected for him. Lastly, the conclusion includes the death of Imam Abu Hanifa and the most important findings of the research.

Previous studies: Numerous books were written on the morals of the Great Imam Abu Hanifa al-Nu'man between lengthy and brief, such as the lives of Abu Hanifa and his companions "Akhbar Abu Hanifa w Ashabeh" by al-Samari, Tabeed Al-Saheefah by Imam Al-Suyuti, the Good Deeds "AlKhayrat Al-Hissan" by Ibn Hajar al-Hitami, the Morals of Imam Abu Hanifa and his both companions "Manaquip Al- 
Imam Abu Hanifa w Sahbayh" by Imam Al-Dhahabī, the strings of pearls "'Uqud Al-Juman" by Al-Sali Al-Shami, and many others.

However, I did not find anyone who concluded a research to explain the Hadithi position of Imam Abu Hanifa except a research of the scholar Muhammad Abdul Rashid AlNumani entitled "The status of Abi Hanifa in Hadith" which is mentioned in the references of this research. The abovementioned research by Muhammad Abdul Rashid Al-Numani was not divided into chapters but points, some of which lead to other, and was filled out approximately $(10$.$) pages, with great$ benefits. I derived benefit from that research in some respects as stipulated in my research, but most of the interest in this book was by transmitting of the late imams such as Al-Mizzi, Al-Dhahabī and others, may Allāh have mercy on them. With their transmission being longer, it may take up all or sometimes most interpretation.

Instead, this research contains more detailed transmissions of the modern and late, and clarifies the attribution of many chains of transmission to their Sayers, with a good arrangement, and Allāh is the one who provides success.

Keywords: Abu Hanifa - The Great - Status - Hadithi Blissful 


$$
\text { بسم الله الرحمن الرحيم }
$$

الحمد لله رب العالمين، أحمده وهو المحمود أزلاً وأبداً، وأشكره مستزيداً من نعمه مسترفاً، وأستعينه وله الحول والقوة سرمداً، وأعتصم به وله وأقف على بابه ونعم المولى ونعم النصير مؤيداً وأثنهد أن لا إله إلا الله إلهاً أحداً فرداً صمداً، وأثنهد أن سيدنا محمداً رسول الهه أرسله بالهدى ودين الحق ليظهره على الدين كله ولو كره الكافرون

اللهم صل وسلم وبارك على سيدنا محمد الفاتح لما أغلق والخاتم لما سبق والناصر الحق بالحق والهادي إلى صراطلك المستقيم صلى الله عليه وعلى آله وصحبه حق قدره ومقداره العظيم

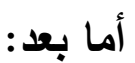

فقد أثنار علي بعض الأكابر من مشايخي إن لم يكن أكبرهم ولو أو أوان أذن أن أصرح باسمه فعلت أن أكتب عن مكانة الإمام أبي حنيفة في الحديث الثربف ان انبرح

فشرعت في جمع المادة العلمية لذلك الموضوع، وكان من الأسباب التي شجعتي على الكتابة في هذا الموضوع مع ما تقدم أن الإمام أبا حنيفة رغم إمامته وديانته وتواتز ثقته وأمانته واستفاضة يقظته ونباهته

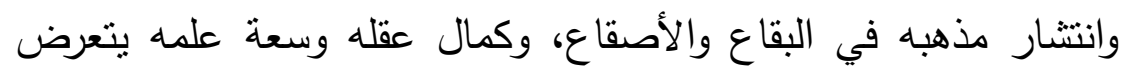

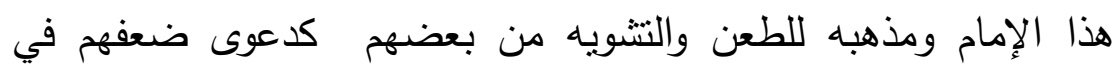

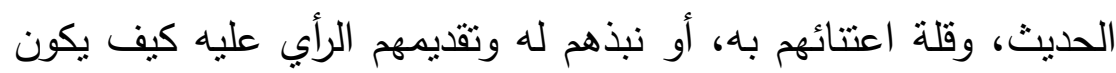
ذللك؟ ومن المعلوم أنه إذا تقرر أن شخصاً ما مجتهد فلا بد أن يفهم حتماً أن لديه مقدار كبير وحظ وافر من علم القرآن والسنة بحيث صار أهلا

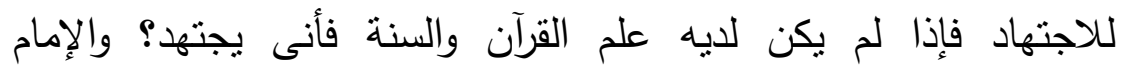
أبو حنيفة هو الإمام الأعظم من الأئمة المجتهدين والفقهاء المتبوعين 
فلا بد وأن يكون رأساً في علمي القرآن والسنة أنسان

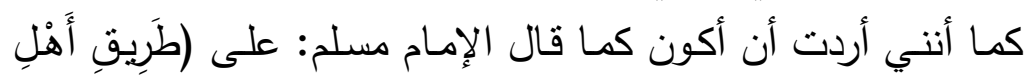

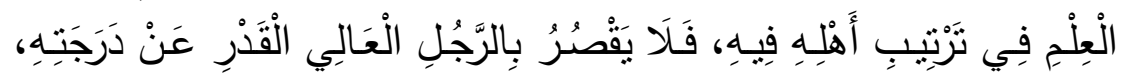

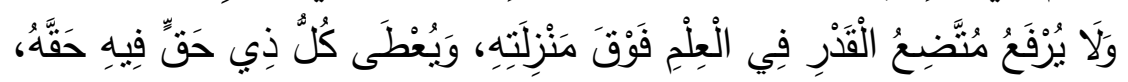

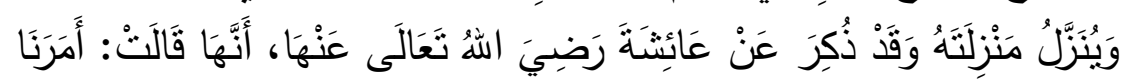

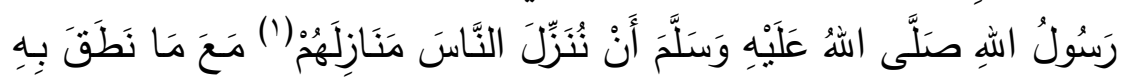

(1) ذكره مسلم هكذا تعليقاً في مقدمة صحيحه (1/7)، أخرجه أبو داود، كتاب الأدب ـ باب في إنزال الناس

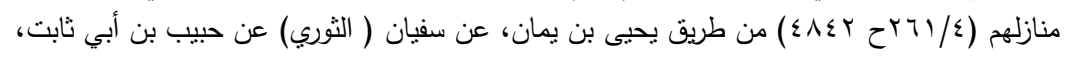

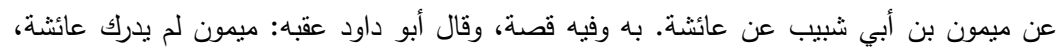

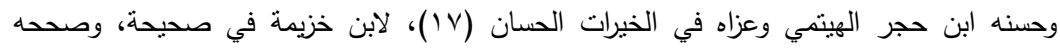

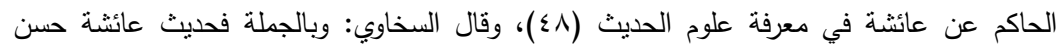

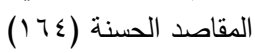

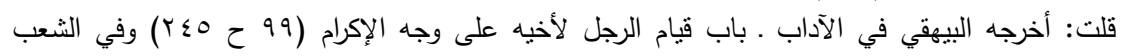

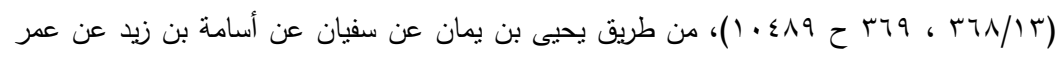

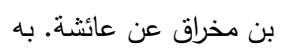

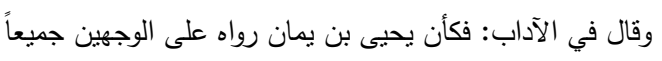

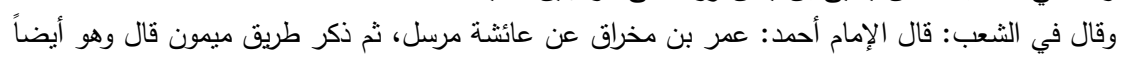
مرسل

قلت: لفظ الحديث في الآداب فقعد معنا وهو يفيد الاتصال ، ولفظه في الشعب: يقعد معها

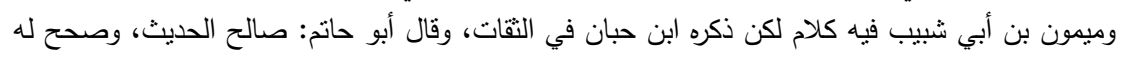

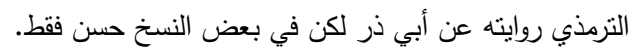

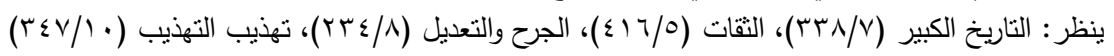

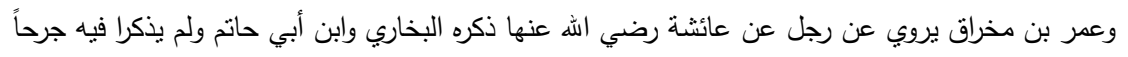

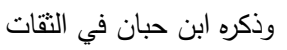

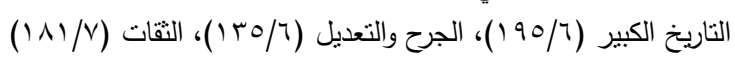

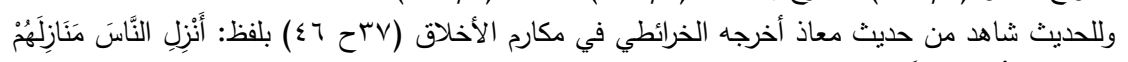

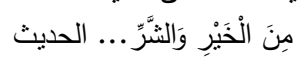

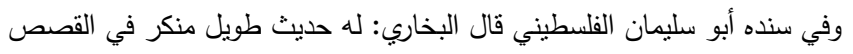

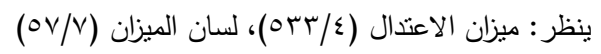

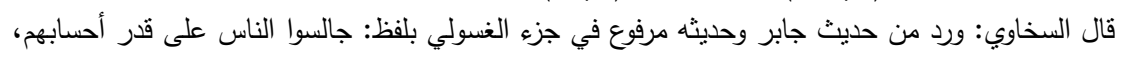

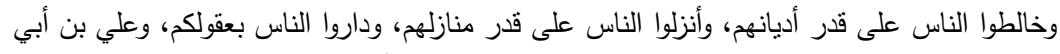

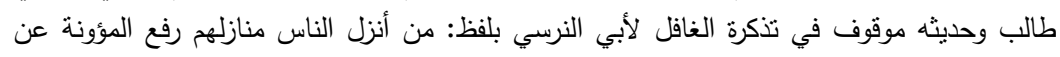

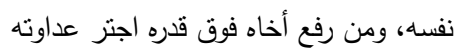

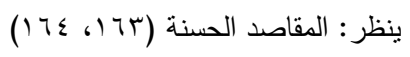




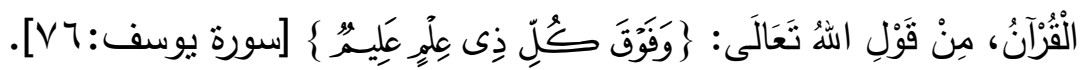

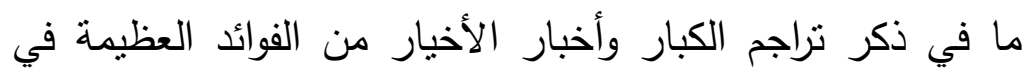

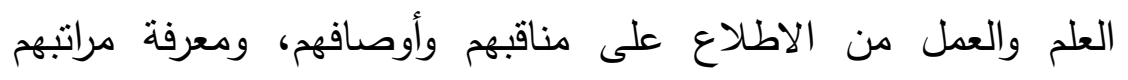

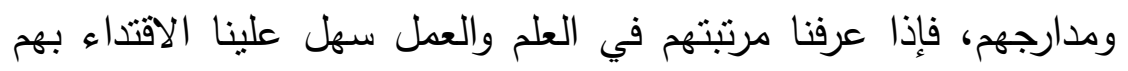

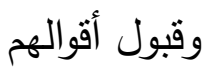
ما وقع في بعض الكتب من الأشياء التي تنافي كمال هذا الإمام

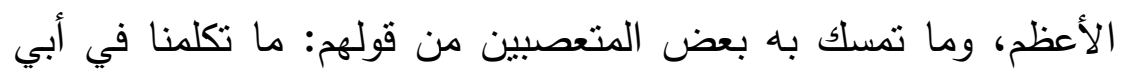

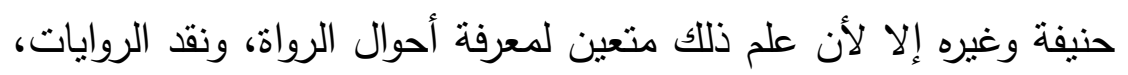

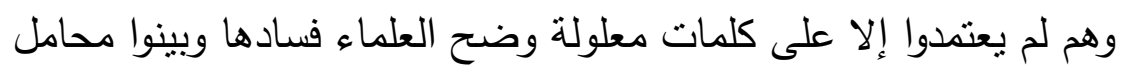
تلاك الكلمات على فرض ثبوت بعضها، بل قد أعرض كثير من العلماء

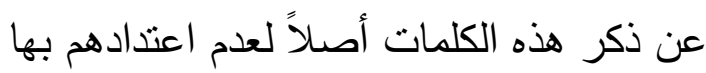

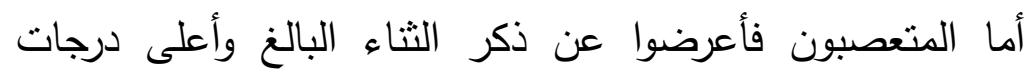

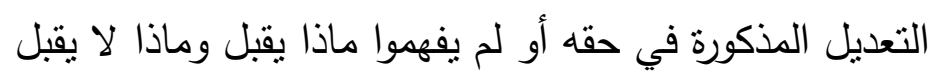

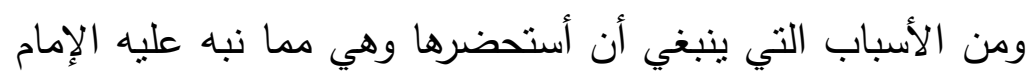

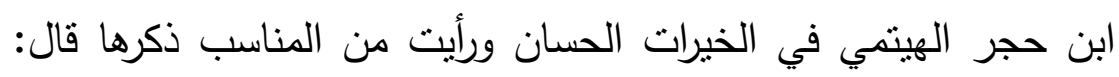

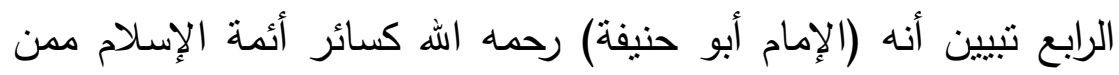

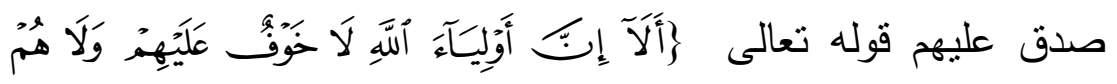

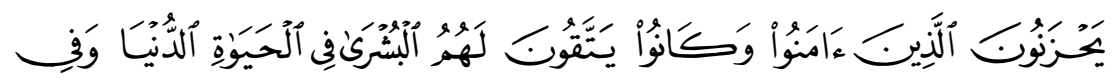

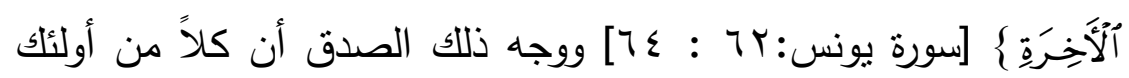

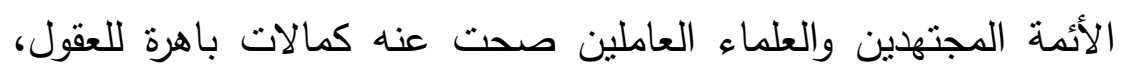
وأحوال وكرامات لا ينكرها إلا المعاند الجهول فهم الأولياء على الحهن الحقيقة

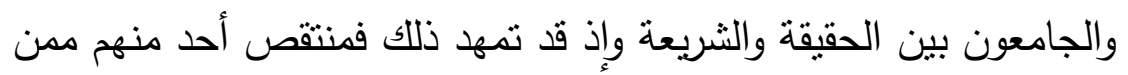

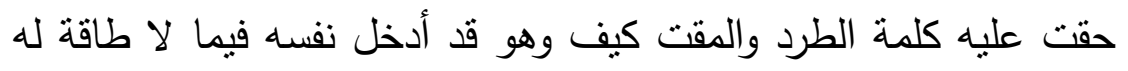

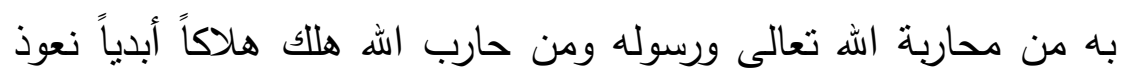




\section{نظرة منيفة إلى المكانة الحديثية للإمام الأعظم أبي حنيفة}

بالهه تعالى من ذلك (')

ويقول ابن عبد البر فمن قرأ (فضائل الأئمة) بَعْدَ فَضَائيلِ الصنَّحَابَةِ

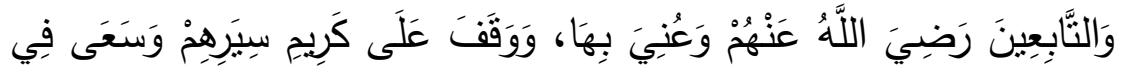

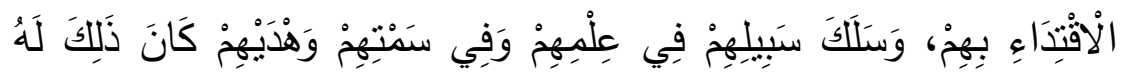

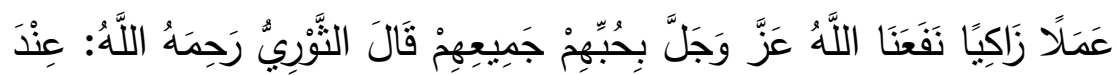

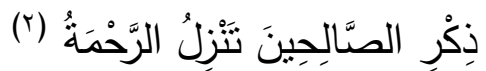

وأخيراً فإن أئعة حفاظاً كباراً قد صنفوا في مناقب هذا الإمام وأطالوا

في ترجمته قديما وحديثا فعسى أن ننتظم في سلكهم لتعود علي بركة هذا الإمام كما عادت عليهم 
وقد قسمت هذا البحث إلى مقدمة وعدة فصول وخاتمة

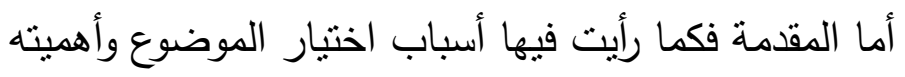

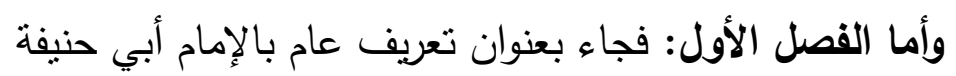
تتاولت فيه اسمه، وكنيته، ونسبه، وولاءه، وأصل بلده بلده ومولداه الفصل الثاني: الإمام أبو حنيفة متعلماً ومعلماً

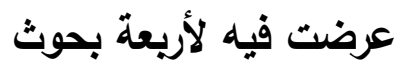

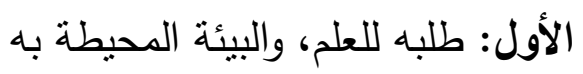

الثاني: طبقته وكونه تابعياً الثالث: شيوخه ورحلاته الرابع: مدرسة الإمام تلاميذه ومنهجه معهم تصنه الفصل الثالث: بيان منزلة الإمام في علم الحديث من خلام تثاء تلثاء العلماء عليه وقد جعته خمسة بحوث الأول: وصفه بأعلى درجات التعديل الثاني: ما جاء من التعديل وبيان عظيم قدره غير ما تقدم الثالث: ما جاء تعديلاً للإمام ودفاعاً عنه إجمالاً

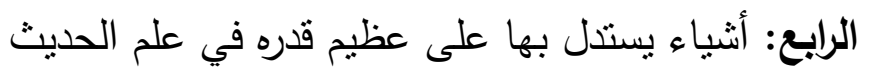
الخامس: بيان كثرة حديثه والمسانيد التي جمعت عنه

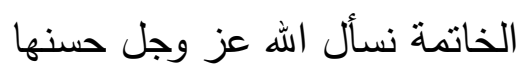
ذكرت فيها وفاة الإمام وأهم نتائج البحث 
الفصل الأول

\section{تعريف عام بالإمام أبي حنيفة}

\section{اسمه ونسبه}

اتفقوا على أن كنيته: أبو حنيفة، واسمه: النعمان بن ثابت وأحيانا يقتصر على ذلك مقتصرون منهم أبو خيثمة، والمدائني،

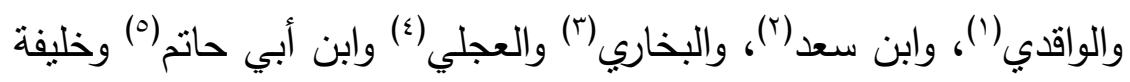

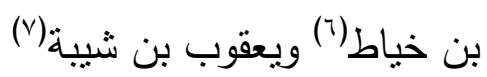
واختلفوا في اسم جده وبقية نسبه

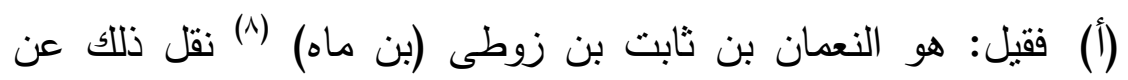
عمر بن حماد بن أبي حنيفة وعن أبي نعيم الفضل بن دكين (9) وذكره

$$
\begin{aligned}
& \text { (1) (1) الانتقاء ص (19) }
\end{aligned}
$$

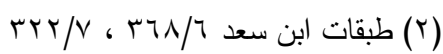

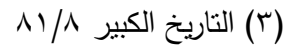

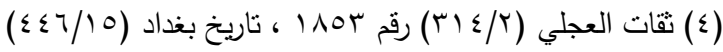

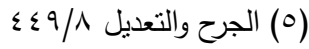

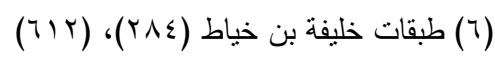

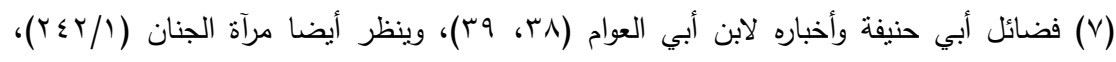

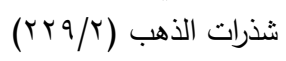

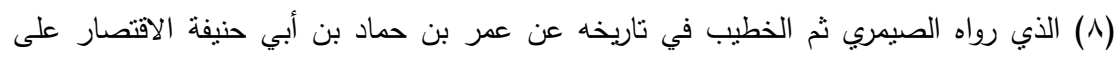

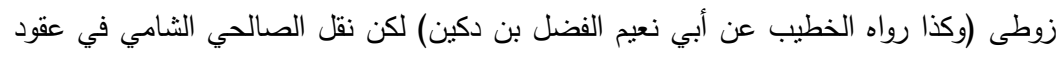

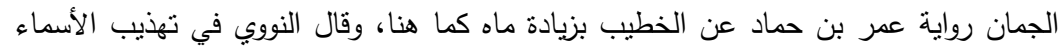

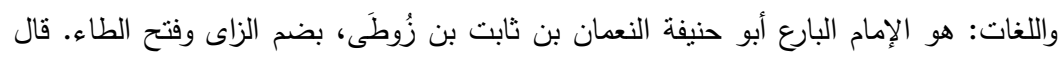

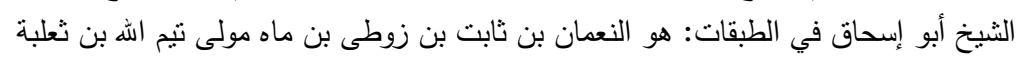

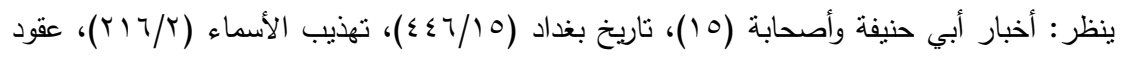

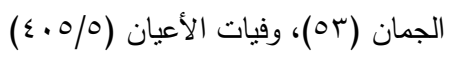

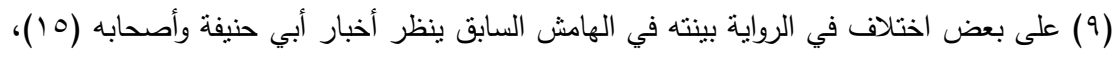

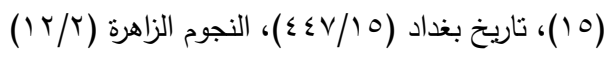


وذكره صاحبا جامع الأصول، وتهذيب الكمال وغيرهما (')

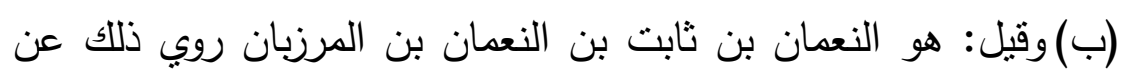

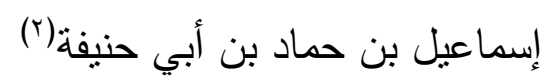

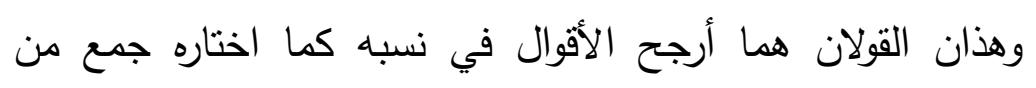
أصحاب المناقب ومن العلماء بعدهم لكونهما مرويان عن حفيدي الإمام(r) الإماح (r) (ب) (ج) وقيل: النعمان بن ثابت بن طاوس بن هرمز ملك بني ساسان، نقل

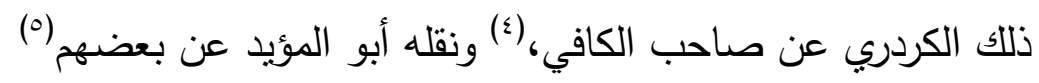
بعضهم (0)

(د) وقيل: النعمان بن ثابت بن زوطى بن يحيى بن راثند أو ابن زيد

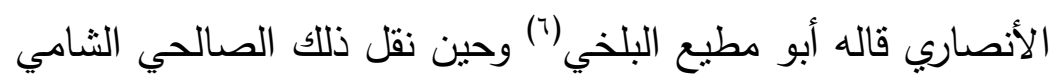
الثامي وصفه بالثذوذ ورده كذلك العلامة محمد أبو زهرة(V) (ه) ونقل محي الدين القرشي صاحب الجواهر المضية في طبقات الحنفية نسب الإمام أبي حنيفة فقال النعمان بن ثابت بن كاوس الإن ...

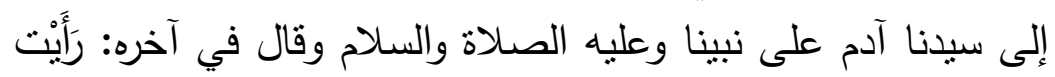

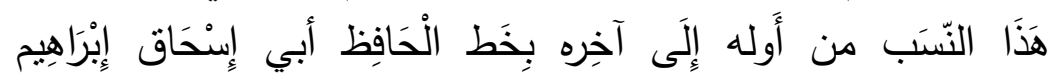

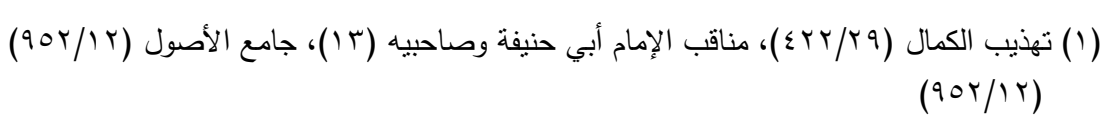

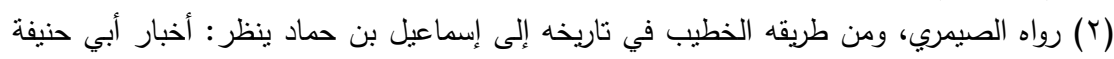

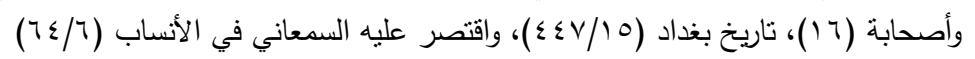

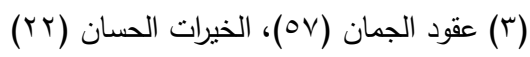

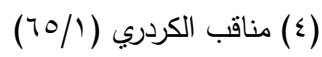

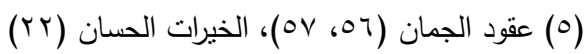

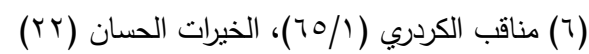

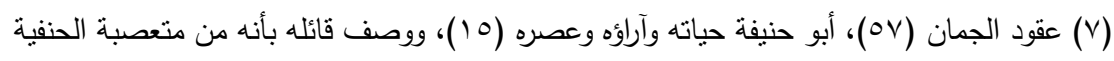
الحنفية 


\section{نظرة منيفة إلى المكانة الحديثية للإمام الأعظم أبي حنيفة}

الصريفيني(') قال الصالحي الثامي: هذا من الغرائب، وقال: هذه

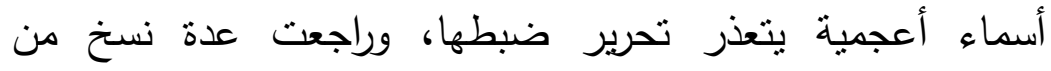

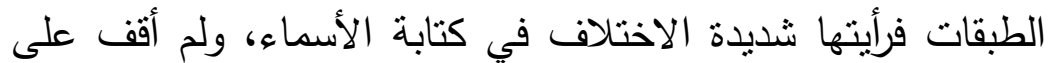

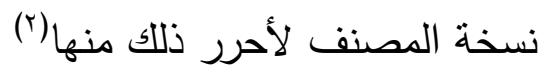
أما الأصل والولاء وما يتعلق بذلكة:

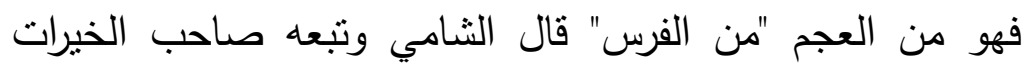

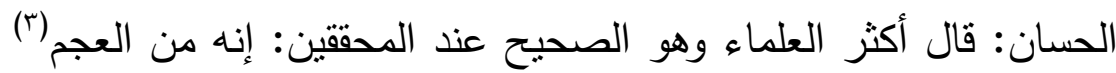
وقال العلامة أبو زهرة: كونه فارسياً هو المشهور الذي الذي يجمع عليه الثقات(ء) وقال الإمام الكوثري: وقد تضافرت الروايات على أن أبا حنيفة كان فارسي النسب(0) قلت: والأقوال في اسم جده كلها تثبت التبات ذلك عدا القول الرابع (د) وقد سبق ما فيه

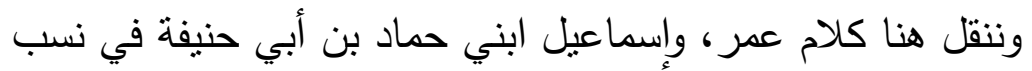
جدهما وقد سبق ذكر اختلافهما في اسم جد الإمام فقال عمر بن حماد:

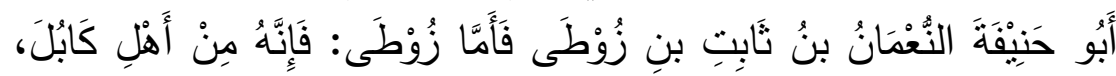

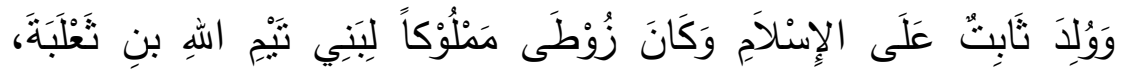

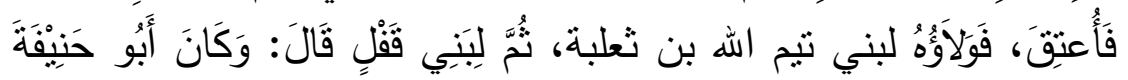

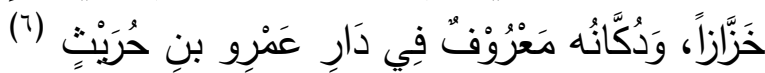

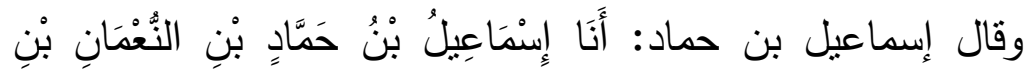

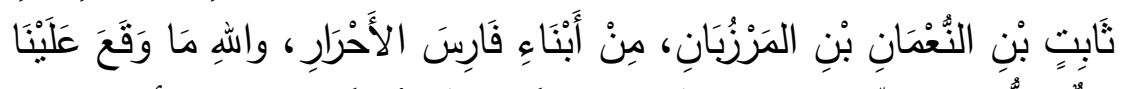

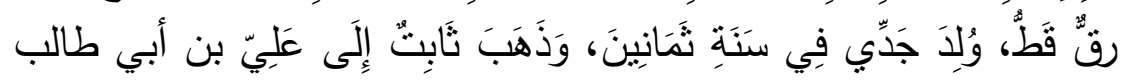

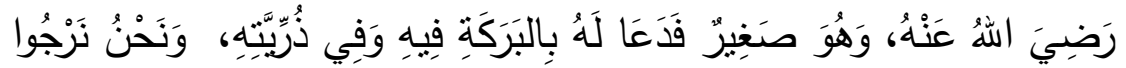

(1) (1) الجواهر المضية (1/1) (1) (1) (1)

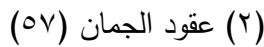

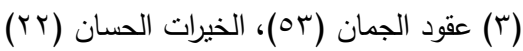

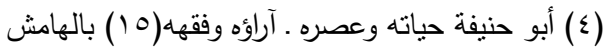

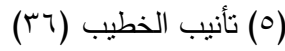

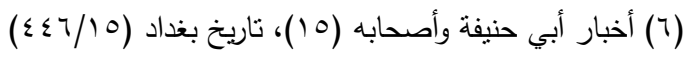




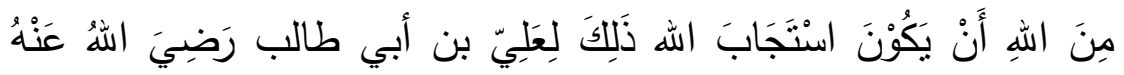

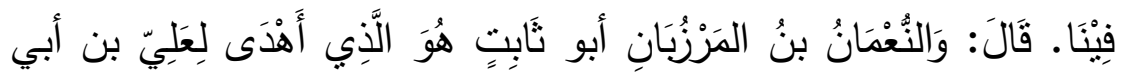

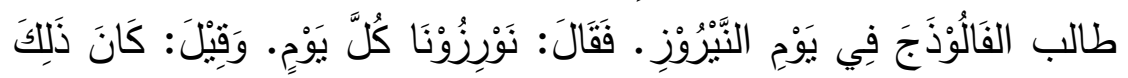

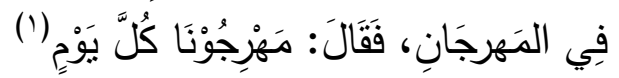

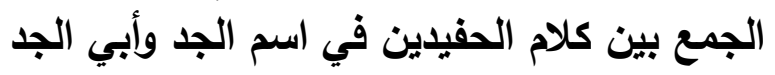

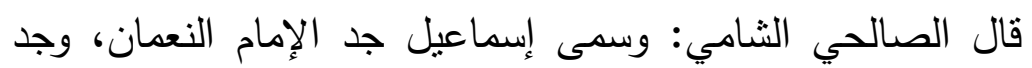

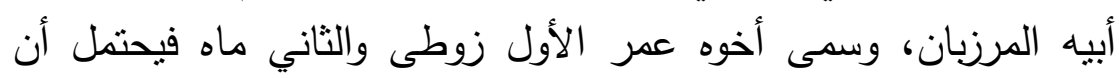

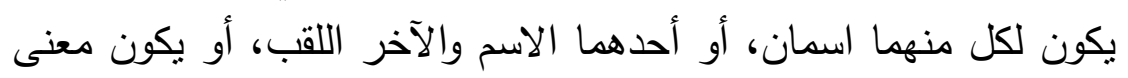

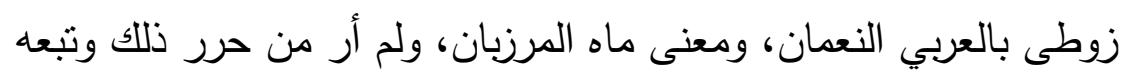

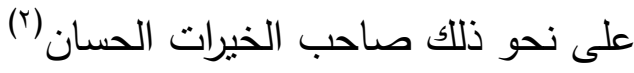
وهناك وجه آخر في الجمع بين كلامهما فقال الإمام الكوثري:

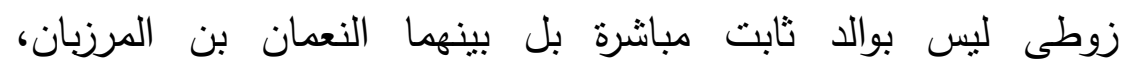

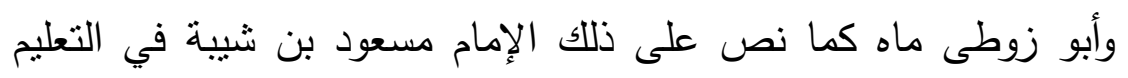

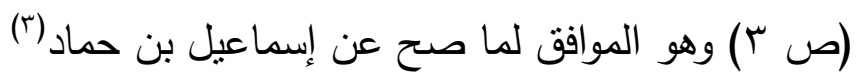
الجمع بين كلامهما في الرق وغيره المان

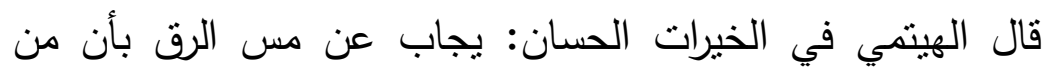

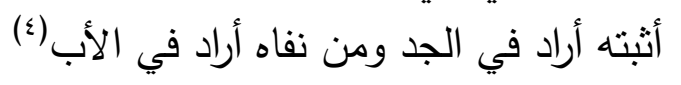

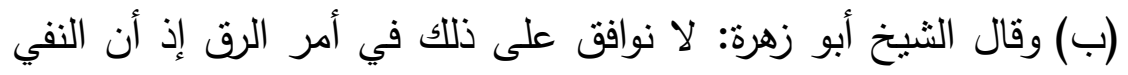

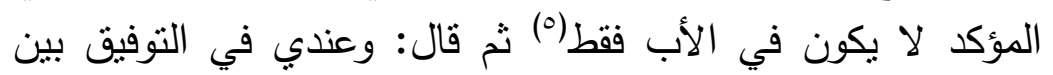

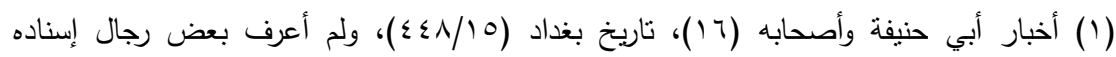

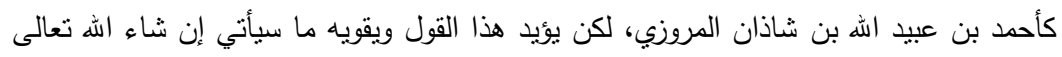

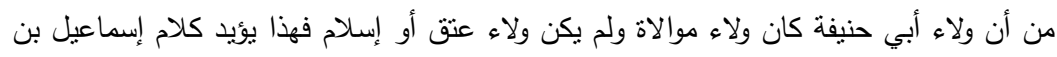

$$
\text { حماد ان ولاد }
$$

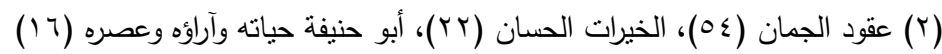

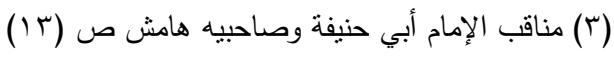

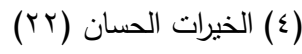

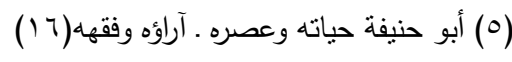




\section{نظرة منيفة إلى المكانة الحليثية للإمام الأعظم أبي حنيفة}

الروايتين أن (الجد) قد أُسِر عند فتح بلاده، ولكن يظهر أنه قد من فئن عليه كما هو الثأن في معاملة المسلمين لبعض كبراء إنداء البلاد

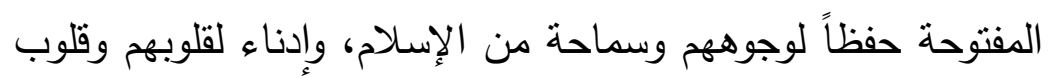

ذوي قرباهم ومن يتصلون بهم (')

(ت) ومما يشير إلى أن الرق لم يجر على ألى أحد من آباء الإمام ما ذكره

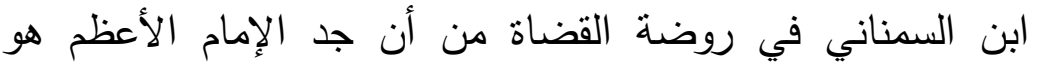

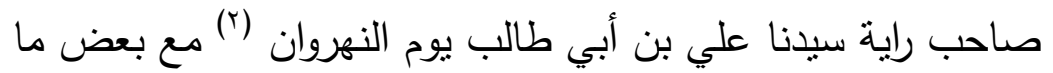

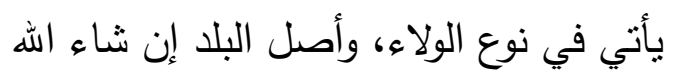

نوع الولاء:

وبناء على كلام عمر بن حماد يكون سبب الولاء لبني تيم الله بن ثعلبة هو الإعتاق

أما على كلام إسماعيل فيحتمل أن الولاء ولاء الإسلام أو ولاء

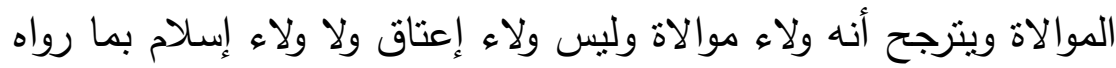

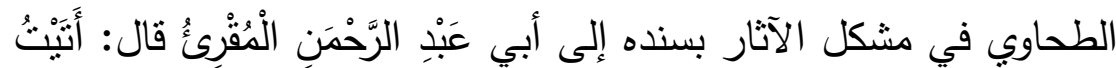

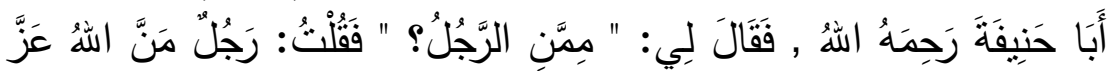

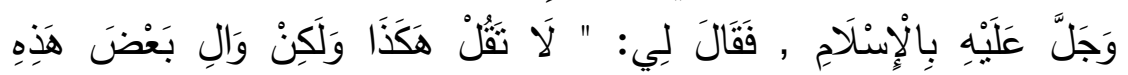

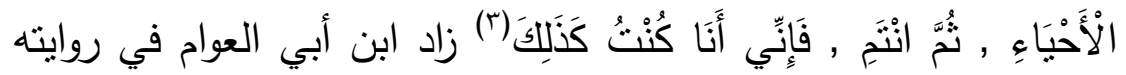

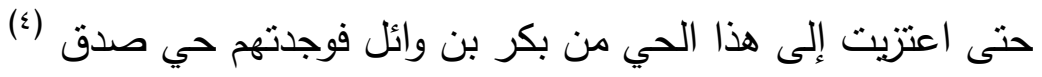

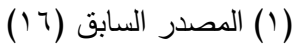

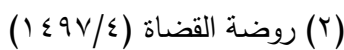

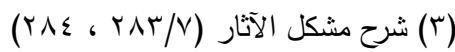

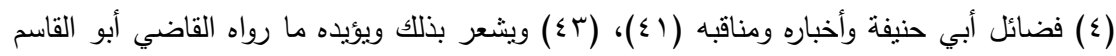

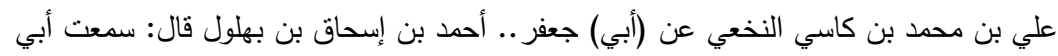

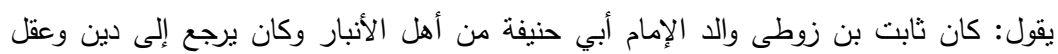

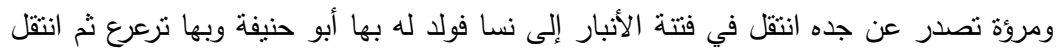

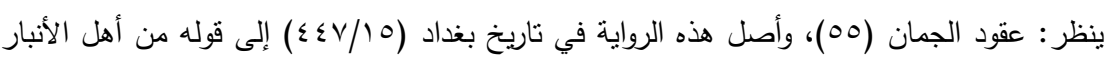

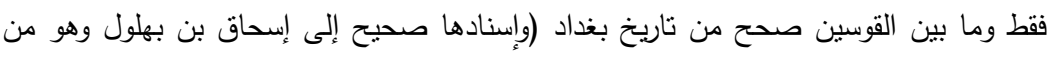




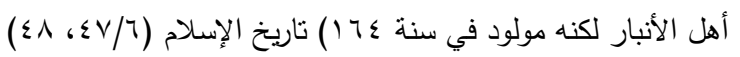


معلوم أن الإمام رحمه الله ورضي عنه نشأ بالكوفة فهو كوفي، وقد

قال العجلي: كوفي تيمي من رهط حمزة الزيات(')

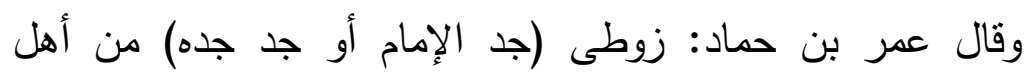

كابل(r) وقال أبو نعيم الفضل بن دكين: زوطى أصله من كابل(r)

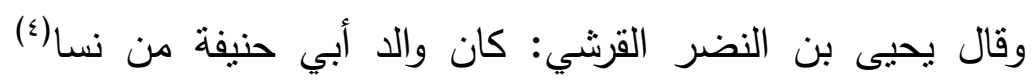
ورويت أشياء أخرى غير هذا والجمع بين هذه الأثياء كما نقل الثامي

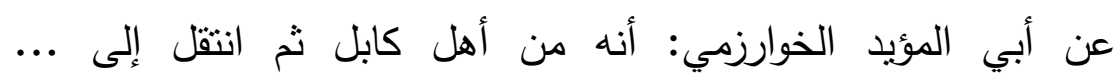
أو بالعكس (ن) مولاه رضي الله عنه: هنالك أقوال (†) في سنة مولده الهه

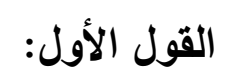
وهو أقواها وأثنهرها أنه ولد سنة ثمانين

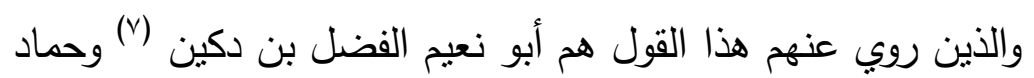
وحماد بن أبي حنيفة (^)

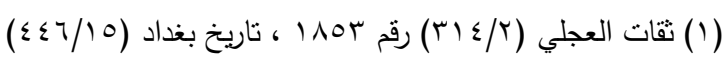

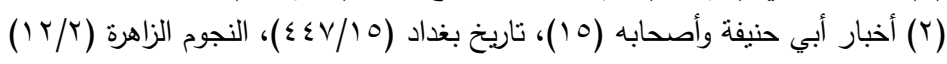

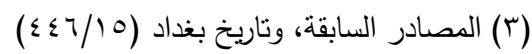

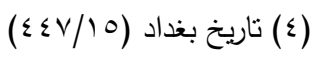

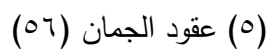

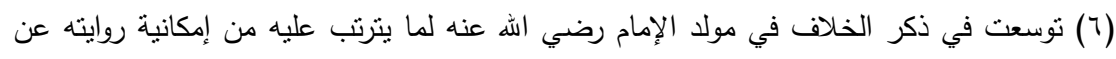

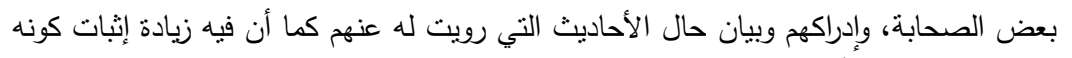

$$
\begin{aligned}
& \text { رضي الله عنه تابعياً }
\end{aligned}
$$

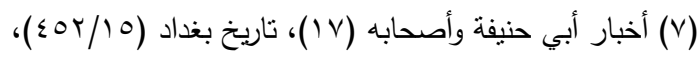

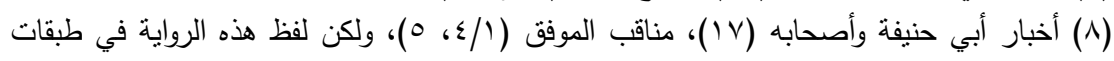

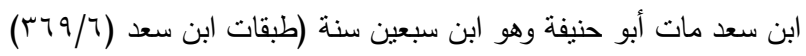


وزفر بن الهذيل حيث قال في ذكر قصته مع أبي جعفر مات في

سنة خمسين (يعني ومائة) وله سبعون سنة(') وأبو يوسف القاضي قال الكردري في مناقبه: وكذا ذكر الواقدي

$$
\begin{aligned}
& \text { والسمعاني عن أبي يوسف(r) } \\
& \text { القول الثاني: } \\
& \text { أنه ولد سنة إحدى وستين }
\end{aligned}
$$

روى ذلك الخطيب عن مزاحم بن ذوَّاد بن علبة عن أبيه أو غيره، وتعقبه الخطيب فقال: ولا أعلم لصاحب هذا القول متابعاً(َ) ووصفها

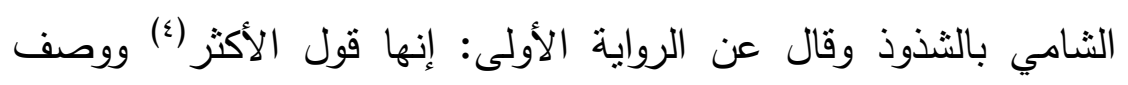
الهيتمي الراوية الأولى بأنها رواية الأكثرين وقال عن الثانية: إنها

مردودة:0)

وقال أبو المؤيد الموفق المكي: وهذه الرواية تخالف ما تقدم

والصحيح هي الرواية الأولى وهي المجمع عليها(؟)

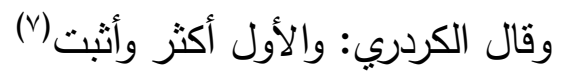

وقال العلامة أبو زهرة: عن الرواية الأولى يكاد يجمع عليها ولهربال

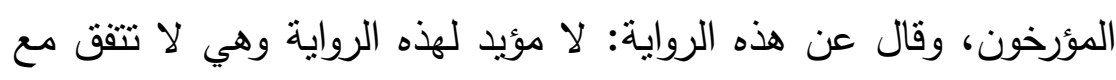

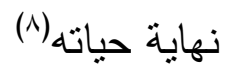

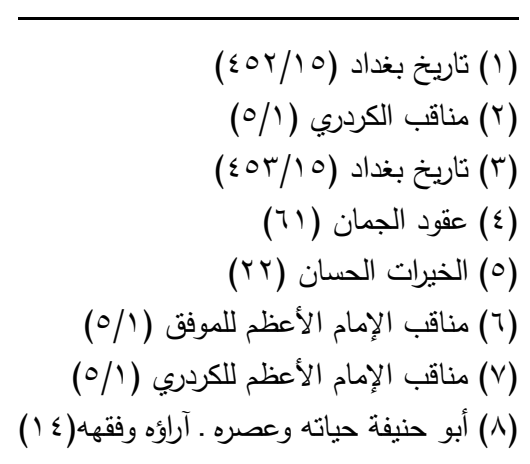


وهؤلاء جميعاً لم يذكروا إلا هاتين الروايتين في مولده

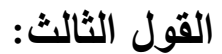

لكن ذكر الإمام القرشي في الجواهر المضية قولاً ثالثاً وهو أنه ولد سنة ثثلاث وستين ولم ينسب هذا القول لأحد وصحح القول الأول أنه ولد سنة ثمانين (') القول الرابع في مولده أنه ولد سنة سبعين من الهجرة ذكر ذلك السمعاني في الأنساب(r)(السمناني في روضة القئ القضاة

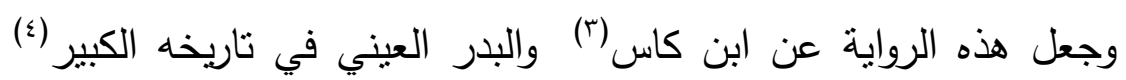
ونقل ذلك الإمام الكوثري عن ابن حبان في الضعفاء والمجروحين المخطوط بمكتبة الأزهر (ن) الأمام مناقشة هذه الأقوال:(7)

ناقش هذه الأقوال في مولد الإمام أبي حنيفة اثثان من الأعلام المعاصرين هما الإمام محمد زاهد الكوثري، والعلامة محمد أبو زهرة أما هواليا

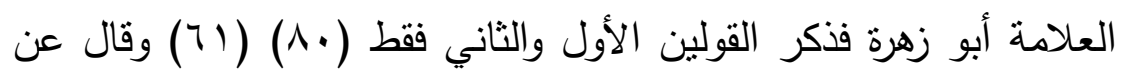

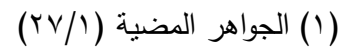

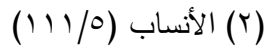

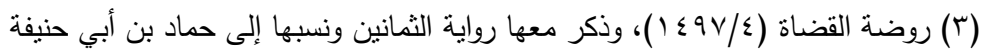

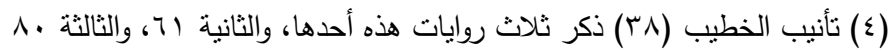

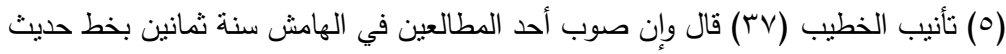

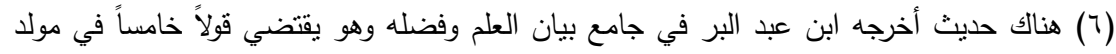

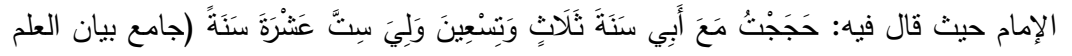

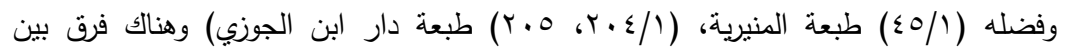

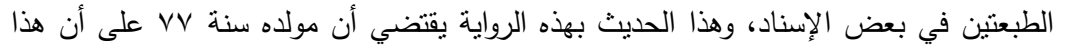

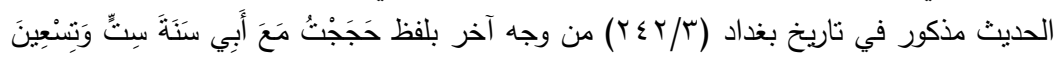
وإنما لم أذكر هذا في الأقوال لتغافل من كتب في المناقب من وجن آخر عنه 
الرواية الثانية لا مؤيد لهذه الرواية وهي لا تتفق مع نهاية حياته لأنه مات سنة ،10 بعد أن أنزل المنصور به المحنة وعلى رواية أنه ولا سنة إحدى وستين يكون إنزال المحنة به لتولي القضاء وهو في سن التسعين، ومن كان في هذه السن لا يعرض عليه ذلك العمل الخطير، ولو عرض إلراء عليه لكان أدنى الحجج إلى طرف لسانه هو تلاك الثيخوخة الفانية، ولكن لم يذكر في أي خبر أو رواية أنه اعتذر بهذا الاعتذار فلا تستقيم إذن هون

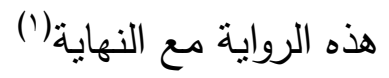

أقول: إنه مع التعنت لا ينفع الاعتذار، أو لعل الإمام لم تظهر عليه آثار هذه الثيخوخة الفانية أما الإمام الكوثري رحمه الله فرجح أن يكون الإمام أبو حنيفة رضي

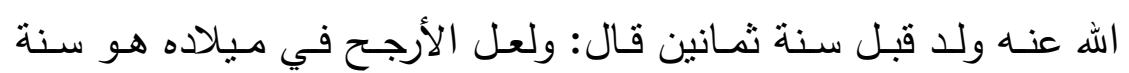
سبعين (ץ) واستأنس واستدل لذلك بعدة أمور ا. منها أن الحافظ محمد بن مخلا العطار ألف كتاباً فيما رواه الأكابر عن مالك وذكر فيه حديثاً من رواية حماد بن أبي حنيفة عن مالك (r) أل

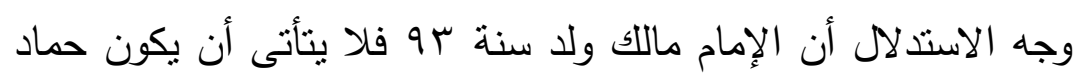

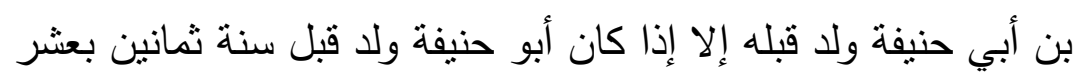

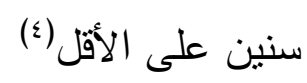

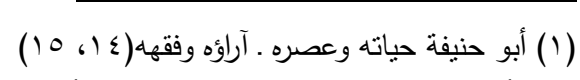

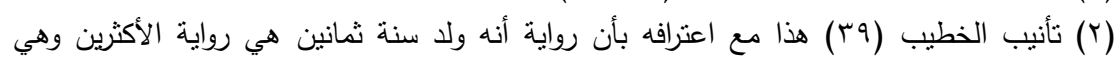

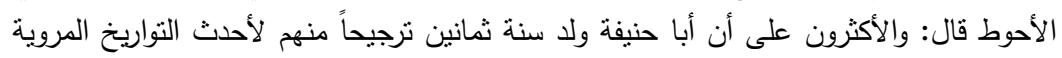

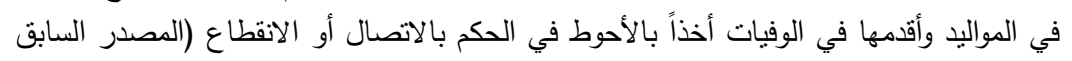

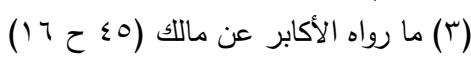

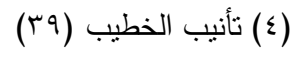




\section{نظرة منيفة إلى المكانة الحديثية للإمام الأعظم أبي حنيفة}

r. ومنها أن العقيلي ذكر قصة مفادها أنه لما مات النخعي اجتمع خمسة من أهل الكوفة منهم الإمام أبو حنيفة وجمعوا نحو أربعين ألف درهم وأعطوها لحماد بن أبي سليمان ليستعين بها ويتقرغ لرياسة الجماعة في

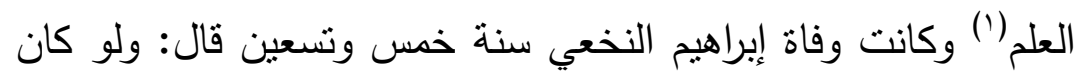
ميلاد أبي حنيفة سنة ثمانين لكانت سنه عند وفاة النخعي خمس عشرة سنة ومن يكون في مثل هذه السنة لا بتصور أن يهتم هذا الاهتمام بمن يخلف النخعي بل لا بد وأن يكون القائمون بمثل هذا الأمر من هن هن

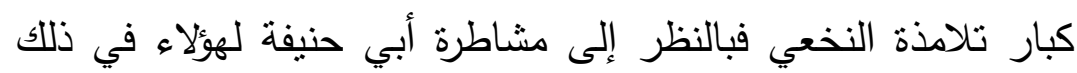
لا بد أن تكون سنة أكبر من هذه السن(أن)

r. منها أنه قد تضافرت الروايات على أن أبا حنيفة قبل انصرافه إلى الفقه كان جدلياً يشتخل بعلم الكلام حتى هبط البصرة نحواً من عشرين مرة ليناظر القدرية وغيرهم ثم انصرف إلى الفقه ومن تككن سنه عند وفاة النخعي ما ذكرنا لا يمكن له الاثتغال الطويل بالجدل قبل انصرافه إلى

الفقه (r)

ع. روايته عن عدة من الصحابة رضي الله عنهم قال: ما كان يصـح كثير

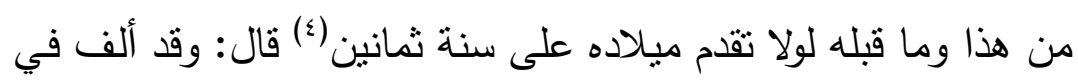
رواية أبي حنيفة لأحاديث عن جملة من الصحابة مباشرة جماعة من

(1) الضعفاء الكبير (1/ • (ץ) وفيه أنهم جمعوا ذلك ليكون رئيسهم في الإرجاء وقد صرح بذلك الإمام

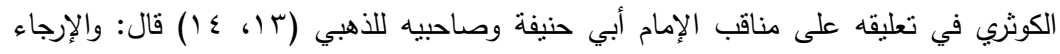
الذي ينسب إليه هو إرجاء السنة فئه علئ

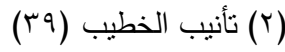

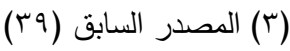

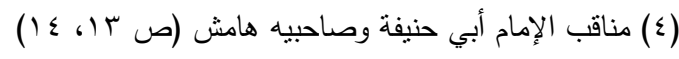


القدماء فذكر بعضـهم ثم قال: وإلى هذه الروايـة(') يكون ميل هؤلاء

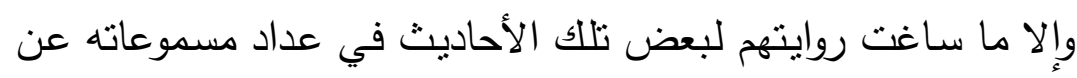

بعض هؤلاء الصحابة مباشرة(r)

أقول: وهذا قول وجيه من الإمام الكوثري ومهع ما دلل بـه عليه فإن سباق بعض الأمور بشـه له، مثل مكثه في بعض رحلاته إلى البصرة

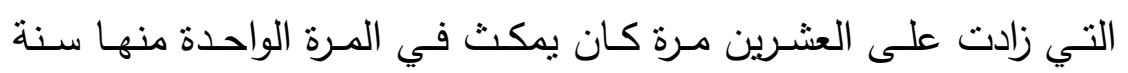
أو أكثر، أو أقل(r) كل ذلك قبل تقرغه التفرغ التام للققه، كما روي أنه حج خمساً وخمسين مرة(؛) ومعرفة الأعمش لفضله وقدره فحين سئل الأعمش عن مسائل قال لأبي حنيفة ما تقول فيها؟ ويستبعد أن يكون ذلك كذلك إذا

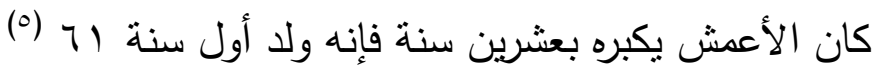

(1) يقصد أنه ولد سنة إحدى وستين

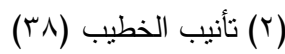

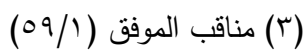

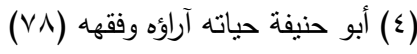

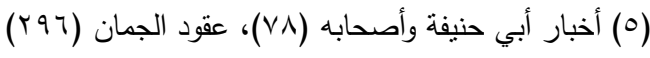




\section{نظرة منيفة إلى المكانة الحديثية لإمام الأعظم أبي حنيفة}

الفصل الثاني

الإمام أبو حنيفة متعلماً ومعلماً

$$
\text { وفيه أربعة بحوث }
$$

\section{البحث الأول: طلبه للعلم والبيئة المحيطة به}

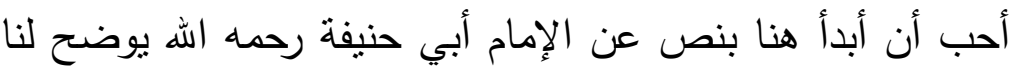

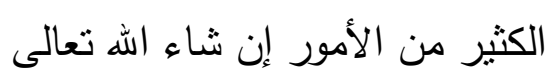

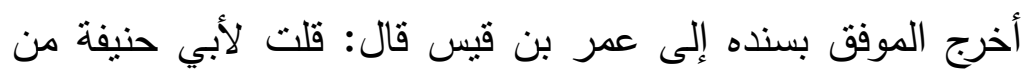
أين للك هذا الفقه؟ فقال لي: كنت في معدن العلم والفقه فجالست أهله،

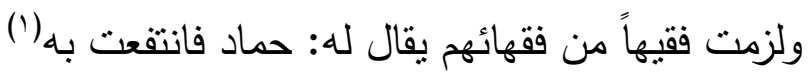

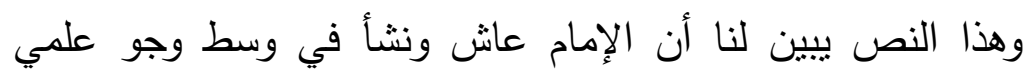
خالط أهله وعرف ما عندهم، وعرف كيفية الاستفادة منهم، ومن الذي لئي

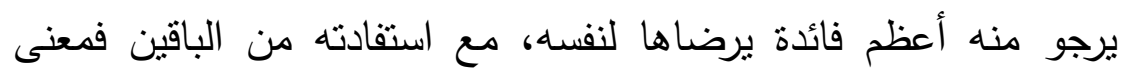

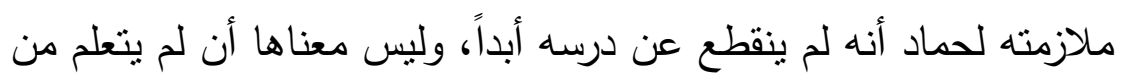

غيره

$$
\text { ا ـ فالنص يفيد أنه تسلح بجميع العلوم الموجودة في عصره }
$$

r. أنه مع أخذه من هذه العلوم بالنصيب الوافر كان همه وانصراف نفات نفسه

$$
\text { إلى الفقه أكثر }
$$

فالبيئة العلمية مهيأة، والاختلاط بأهل العلم موجود، والاختيار الذي

$$
\text { حدث، كان مع معرفة بما عند الجميع من العلم }
$$

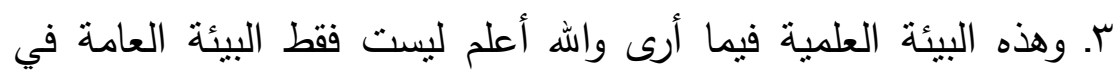
الكوفة أو العراق الذي كان بزخر بالفرق الإنسامية المختلفة، وكان فيه 
التابعون المجتهدون، الذين حملوا علم من لقوا من الصحابة رضي الله

عنهم

بل هي البيئة الخاصة أيضاً في الأسرة والبيت ونحو ذلك فيبدو أن أهل بيته كان لهم اهتمام شديد بالعلم واختلاط بالعلماء والصالحين

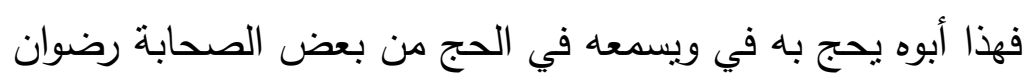
الله عليهم على القول بأنه سمع منهم(') وما أمر جده مع أبيه عند سيدنا علي رضي الله عنه بخاف وقد سبق في اسمه ونسبه فالأسرة أسرة تهنت بالعلم والسماع والتحصيل ويقول الإمام أبو حنيفة: لقيت عطاء بمكة، فسألته عن شيء، فقال: من أين أنت؟ قلت: من أهل الكوفة، قال: أنت من أهل القربة الذين فرقوا دينهم وكانوا شيعا؟ قلت: نعم، قال: فمن أي الأصناف أنت؟ قلت: ممن لا يسب السلف، ويؤمن بالقدر، ولا يكفر أحدا بذنب، قال: فقال لي

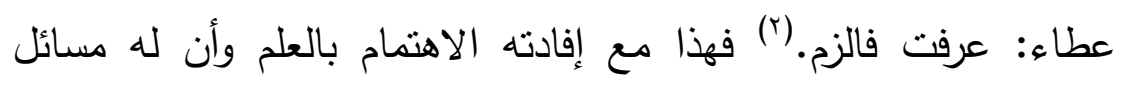
خاصة يسأل عنها يفيد كذللك أنه عرف الفرق المختلفة ولم يتأثز إلا بالصواب على النشأة التي نشأ عليها، بل كانت له مناهج فيما برومه

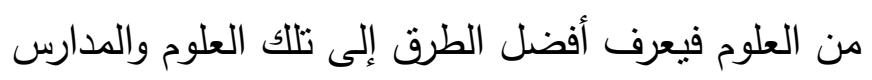
فهذا أبو جعفر المنصور الخليفة يسأل الإمام فقال له: يا نعمان إنمان

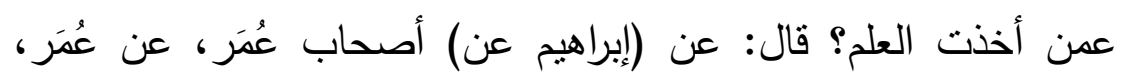
وعن أصحاب علي، عن علي، وعن أصحاب عبد الله، عن عبد الله، وما

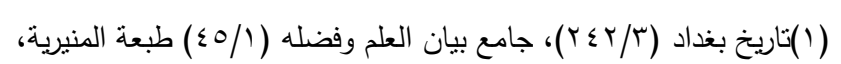

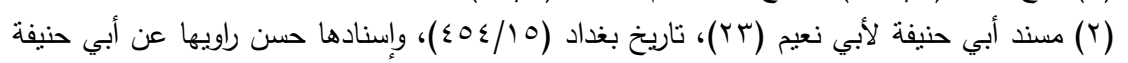

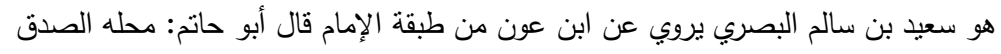

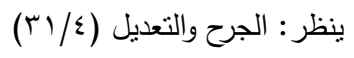




\section{نظرة منيفة إلى المكانة الحليثية للإمام الأعظم أبي حنيفة}

كان في وقت ابن عباس [رضي الله عنهم أجمعين] على وجه الأرض

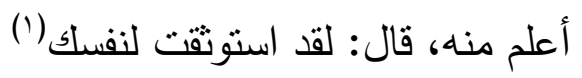

وفي ضوء هذا الكلام ينبخي أن نفهم روايات بداية طلبه للعلم

فقول الثعبي للإمام أبي حنيفة: عليك بالنظر في العلم ومجالسة

العلماء فإني أرى فيك يقظة وحركة(؟)

كما يفيد أنه كان ينصرف إلى السوق ويتعلم التجارة، كذلك يفيد أنه كان يجالس العلماء حتى إن الشعبي لحظ نبوغه وتقوقه فأراد منه أن يتقرغ للعلم تفرغاً تاماً ولذلك قال الإمام بعدها: فوقع قوله في قلبي فتركت الاختلاف إلى

السوق وأخذت في العلم فنفعني الله تعالى بقوله(؟) كذلك ما روي عن الإمام رضي الله عنه أنه نظر في عاقبة كل علم من العلوم، وفائدته كالقراءت، والنحو، والحديث، والكلام فرأى أن أسلمها

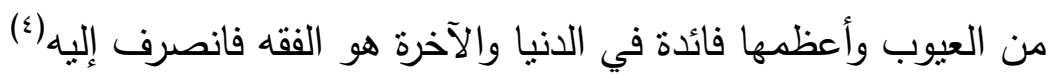
ليس معناه أنه لم يدرس شيئاً في بقية العلوم قبل الفقه، وبعده، ومعه بل معناها أن ذلك هو سبب عظيم اهنمامه بالفقه، أو تخصصه

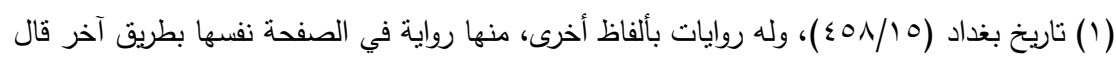

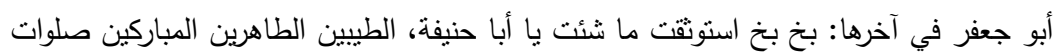
الله عليهم

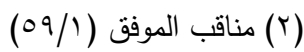

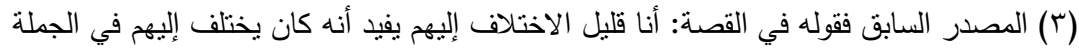

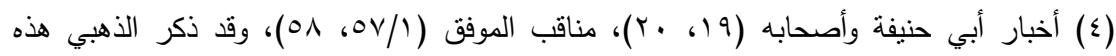

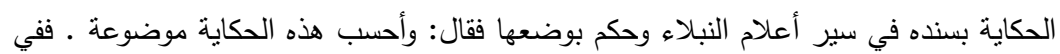

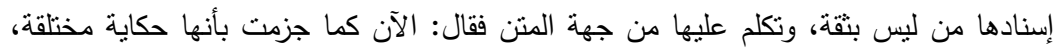

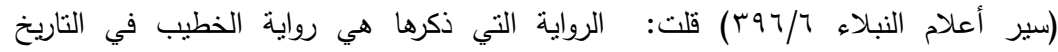

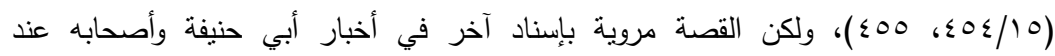
الصيمري، وبإسناد ثالث عند الموفق في مناقبه وأمر المتن يحتمل الثنأويل. 
الاقيق فيه، لأنه قد ثبت أنه أخذ القراءة عن عاصم(') وثبت أنه طلب

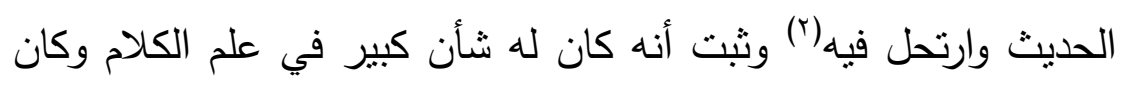
يجادل الفرق المختلفة بالبصرة وغيرها حتى نزل البصرة أكثر من عشرين مرة يجادل أهل الأهواء كل ذللك قبل تقديمه لفائدة علم الفقه على فائدة

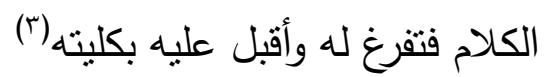

هذا ومع إلقائنا الضوء على البيئة العلمية الخاصة والعامة التي ساعدت في طلب الإمام أبي حنيفة رحمه الله للعلم، نشرع الآن في بيان طبقته وكونه رضي الله عنه تابعياً

(1) الخبرات الحسان (1^)

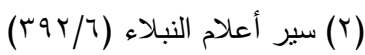

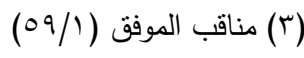




\section{نظرة منيفة إلى المكانة الحديثية للإمام الأعظم أبي حنيفة}

\section{البحث الثاني: طبقته وكونه تابعياً}

أما طبقته رحمه الله فهو من التابعين رأى بعض الصحابة كأنس بن

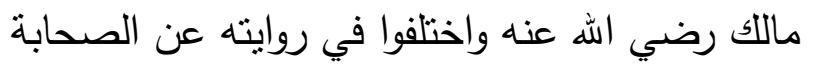

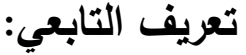

التابعي هو مـن لقي الصـحابي، فقد جعل الحـاكم آخر طبقات التابعين من لقي أنس بن مالك من أهل البصرة، ومن لقي عبد الله بن الن الهي

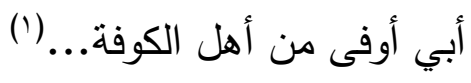

قال ابن الصلاح: والاكتفاء في هذا بمجرد اللقاء والرؤية أقرب منه الكها..

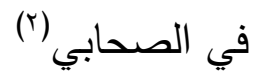

قال النووي: وهو الأظهر (r)

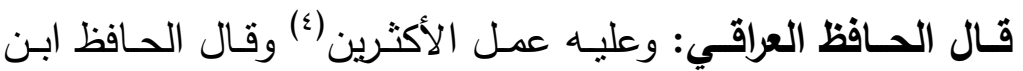

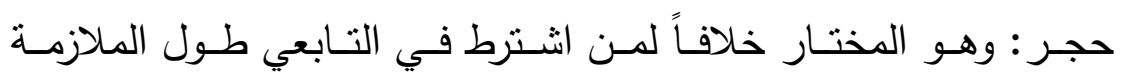

أو صحة السماع أو التمييز (o)

هل رأى سيدنا أبو حنيفة الصحابة أو روى غنهج؟

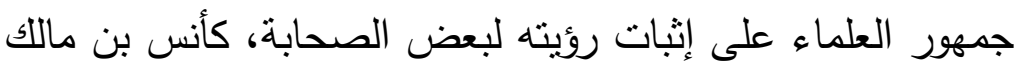

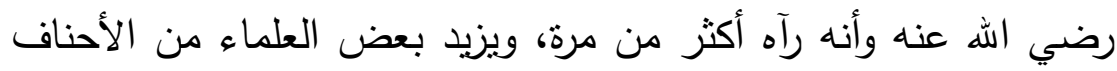
وغيرهم سماعه من بعضهم، فهو على كلا التقبرين نابعي كما هو المختار في تعريف التابعي وهناك القليل من العلماء نفى عنه الرؤية والسماع معاً وهم قليل

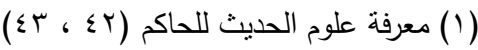

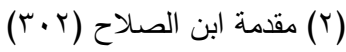

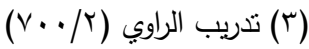

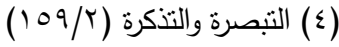

(0) نزهة النظر (1) (1) (1) (1) (1) 
ولعل أول من نسب إلبه ذللك الإمام الدارقطني وفي النقل عنه اختلاف كثير ثم من جاء بعد الإمام الدارقطني فكثير منهم لبسوا من أهل الحديث

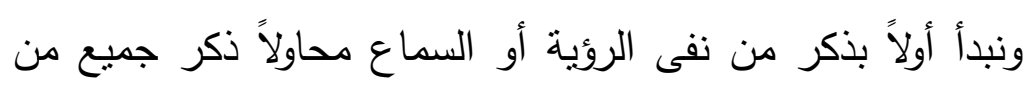
قال بذللك،

ثم أذكر من أثبت رؤيته للصحابة رضي الله عنهم ثم أورد من قال بسماعه منهم وهذا ما أميل إليه لما بأتي

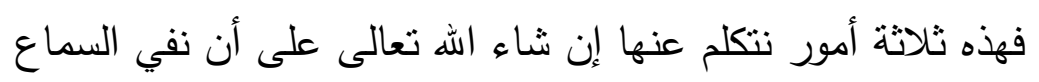
لا يعني أنه ليس بتابعي كما ذكرت فإن كثيراً ممن نفى السماع أثبت الرويةية

من نفى سماع الإمام من الصحابة أو روئيه لهم:

وهؤلاء منهم من نفى السماع فقط، ومنهم من نفى السماع والروئية

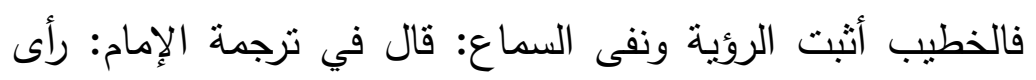

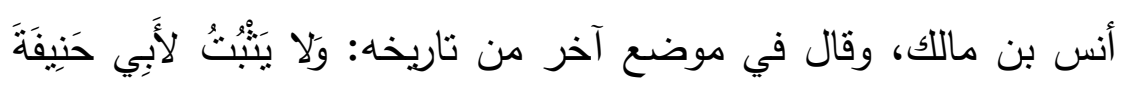

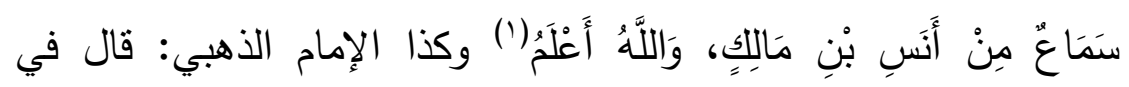

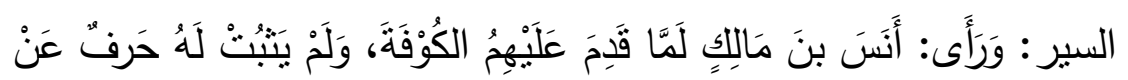
أَحَدِ مِنْهُمُ (؟) وسيأتي إن شاءِ الله نقل بقية كلام الذهبي في كون الإمام أبو حنيفة من التابعين

أما الدارقطني فنقل عنه نقلين في ذلك: ففي سؤالات السهمي (ॅ): سئل الدارقطني وأنا أسمع عن سماع أبي حنيفة من أنس يصح؟ قال:

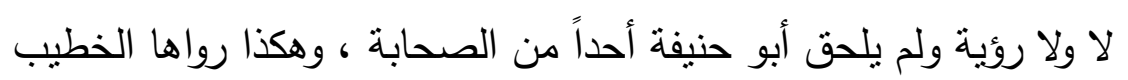

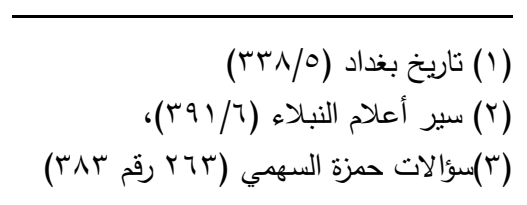




\section{نظرة منيفة إلى المكانة الحليثية للإمام الأعظم أبي حنيفة}

من طريق السهمي (')

أما السيوطي فنقل في تبييض الصحيفة: قال حمزة السهمي: سمعت الدارقطني يقول: لم يلق أبو حنيفة أحداً من الصحابة إلا أنه رأى أنساً

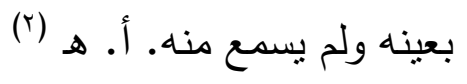

فقد اختلفت نسخ السؤالات في ذلك فالذي نقله السيوطي غير الذي نقله الخطيب لكن ما نقل عن الإمام الدارقطني من قوله: لم يلحق أحداً من الصحابة. لا يوافق عليه أحد وهذا من مرجحات ما ذكره السيوطي مالي عن الدارقطني، ولعل كل من نفى الرؤية أو السماع هو من جاء بعد هله الدارقطني وهذا حال النقل عنه كما ترى وقال أبو إسحاق الثيرازي في طبقات الفقهاء: وقد كان في أيامه أربعة من الصحابة: أنس بن ماللك وعبد الله بن أبي أوفى الأنصاري وأبو الطفيل عامر ين وانتة وسهل بن سعد الساعدي وجماعة من التابعين كالثعبي والنخعي وعلي بن الحسين وغيرهم... ولم يأخذ أبو حنيفة عن

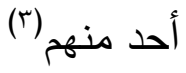

وهذا ليس فيه نفي رؤية الصحابة فنفي الأخذ عنهم غير نفي رؤيتهم، كما أنه زاد هنا نفي أخذه عن بعض التابعين أيضاً وقال صاحب أسماء رجال المشكاة: كان في أيام أبي حنيفة أربعة الهاء من الصحابة أنس بالبصرة وعبد الله بن أبي أوفى بالكوفة، وسهل بن سعد

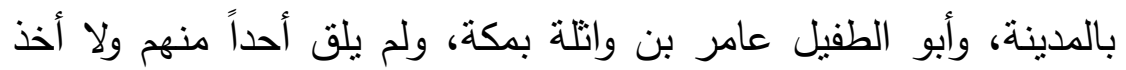

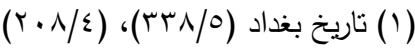

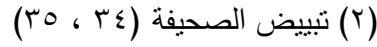

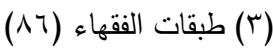


(1) (1)

وهناك من ينسب القول بعدم السماع والروئية لأهل النقل ولا يبين

من نقل عنه

فقال ابن الأثير في جامع الأصول: وكان في أيام أبي حنيفة أربعة من الصحابة: أنسُ بن مالك بالبصرة، وعبد الله بن أبي أوفى بالكوفة،

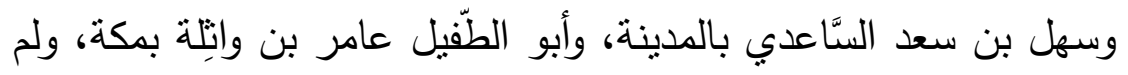
يلقَ أحداً منهم ولا أخَذَ عنه؛ وأصحابُه يقولون: إنه لقي جماعة من إنه

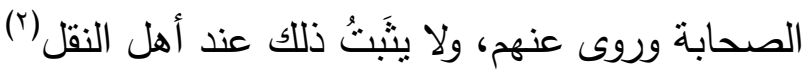
وقال ابن خلكان: وأدرك أبو حنيفة أربعة من الصحابة، رضوان الله عليهم وهم: أنس بن ماللك وعبد الله بن أبي أوفى بالكوفة، وسهل بن سعد أن

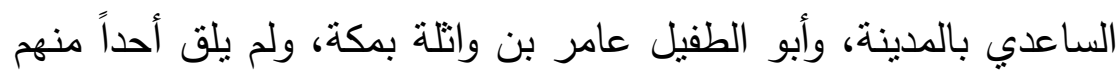
ولا أخذ عنه، وأصحابه يقولون: لقي جماعة من الصحابة وروى عنهم، ولم يثبت ذللك عند أهل النقل. وذكر الخطيب في " تاريخ بغداد " أنه رأى

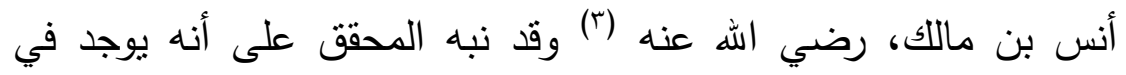
نسختين خطينتين (ولم يلق أحداً منهم إلا وأخذ عنه)

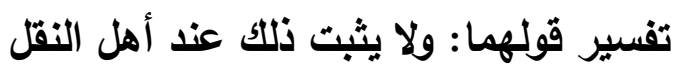
قبل الخوض في تفسير ذلك أذكر نقلاً عن الإمام البافعي في مرآة الجنان قال في ترجمة الإمام: رأى أنساً وروى عن عطاء وطبقته وكان قد أدرك أربعة من الصحابة .... قال بعض أصحاب التاريخ: ولم ير أحداً منهم ولا أخذ عنه وأصحابه يقولون لقي جماعة من الصحابة وروى عنهم

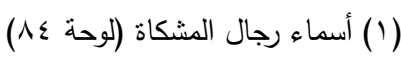

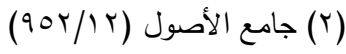

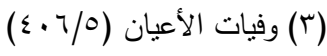




\section{نظرة منيفة إلى المكانة الحديثية للإمام الأعظم أبي حنيفة}

ولم يثبت ذلك عند أهل النقل(') فهو أولاً أثبت رؤية الإمام لسيدنا أنس

وثانياً: نسب القول بعدم الروئية والأخذ لأهل التاريخ وليس لأهل الحديث المتخصصين في ذلك، فإذا كان الإمام اليافعي جمع بين إثبات الروئية، ونفي البعض للقاء والأخذ فإن المذكور قبل (ذلك في قولهم ولا يثبت ذلك عند أهل النقل) هو الرواية والملاقاة فتقيد أن تحقق هذين الأمرين معاً غير ثابت، وأما اللقاء وحده فلا وكذلك المذكور قبلها هو لقاء جمع من الصحابة فتدل على عدم ثبوت لقاء جمع من الصحابة لا على ثبوت رؤية صحابي، كناء كنه

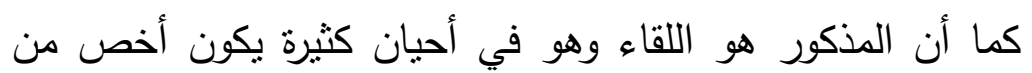
الروية، وانظر نقل السيوطي في تنييض الصحيفة عن الدارقطني: قال لم يلق أبو حنيفة أحداً من الصحابة إلا أنه رأى أنساً بعينه ولم يسمع منه(r) فقد نفى اللقاء وأثتبت الرؤية (r) وهذا واضح أيضاً في كلام ابن خلكان فإنه قال بعد ذلك وذكر الخطيب في تاريخ بغداد أنه رأى أنس بن ماللك فكأن ابن خلكان لم يقصد نفي الرؤية وإنما أراد نفي السماع ثم إن في كلامهما مأخذ آخر بينه البدر العيني فقال: ما نقله أصحابه أولى من غيرهم، والرجوع إلى ما نقلوا أولى مما نقله غيرهم؛

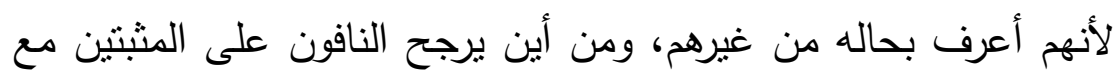
ادعاء كل طائفة من الطائفتين أنهم ثقات أثنات فى النقل والرواية؟! وهذه يره 
معارضة بالمثل، فترجح رواية المثبت لكونها تثبت أمرًا زائدًا، فتأمل.

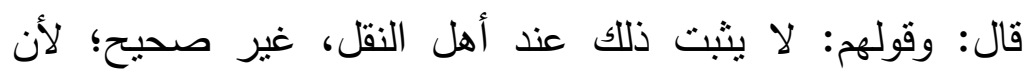

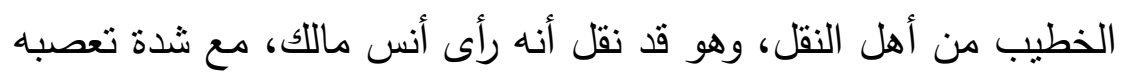

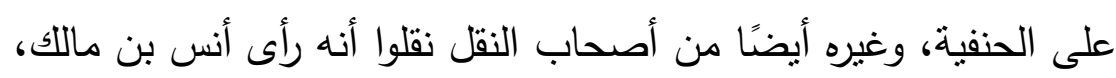

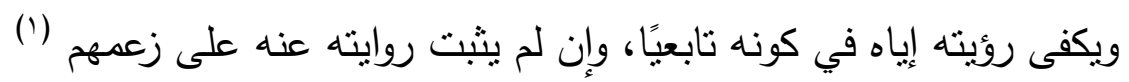

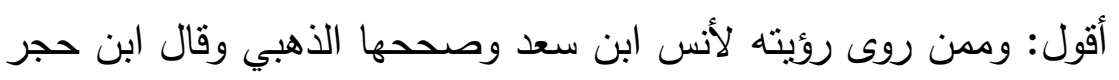
بسند لا بأس به كما سيأتي هذه جملة أقوال من نفوا سماع سيدنا أبي حنيفة من الصحابة ولم

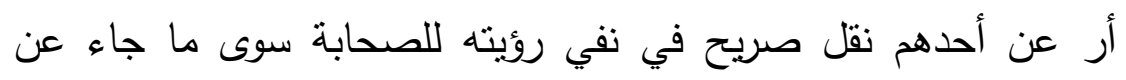

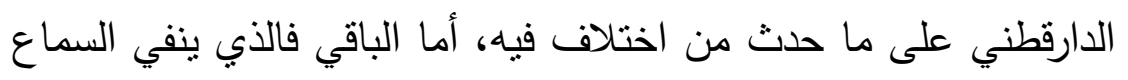
يثبت الرؤية ومن نفى اللقاء فكلامه محتمل أو هو ناقل لم يبين من نقل فئل

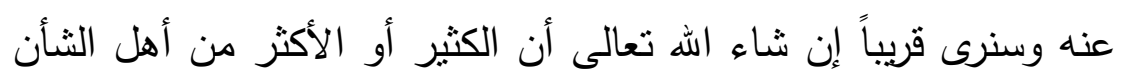

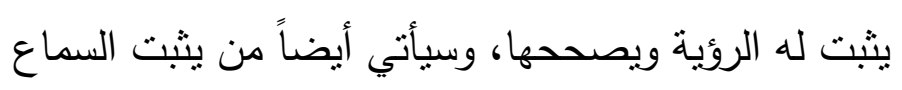
من يثبت روئية الإمام أبي حنيفة رحمه الله للصحابة رضي الله عنهم:

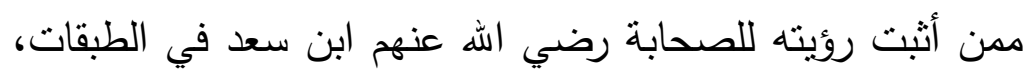

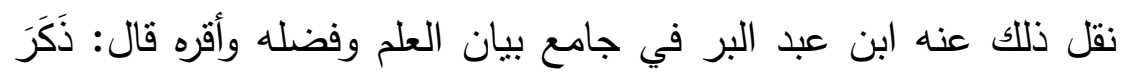

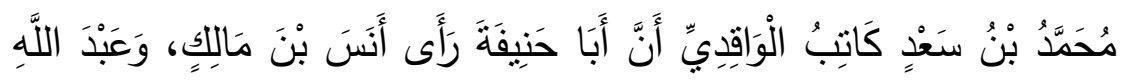

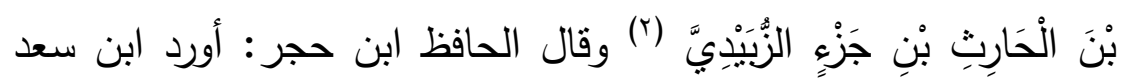

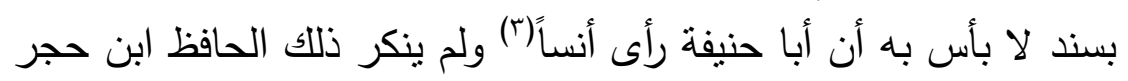

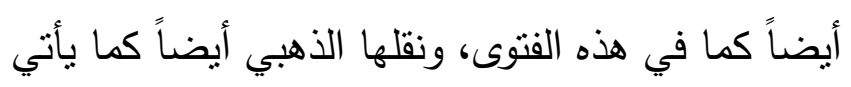

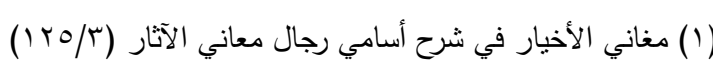

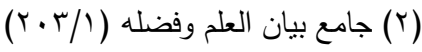

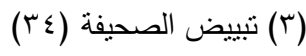




\section{نظرة منيفة إلى المكانة الحليثية للإمام الأعظم أبي حنيفة}

والحافظ أبو نعيم قال في مسند أبي حنيفة: (ذكر من رأى من

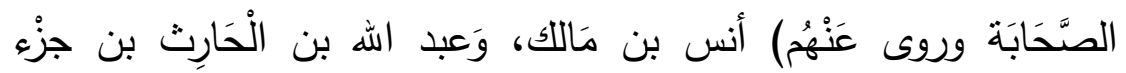

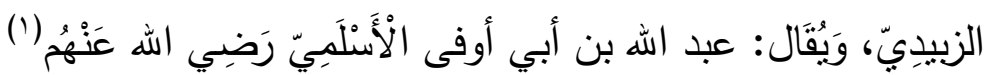

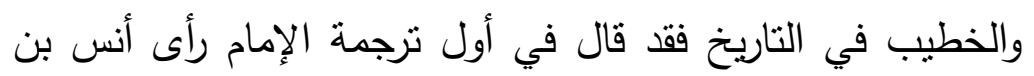

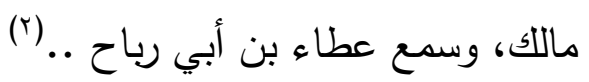
وأبو زكريا السلماسي في منازل الأئمة: قال: ورأى أنس بن مالك بـ لكاح

وسمع منه (r)

واليافعي في مرآة الجنان (؛)

والذهبي في كتبه كالكاثف وغيره أثبت رؤيته لسيدنا أنس (0) وقال في كتابه مناقب أبي حنيفة: وكان من التابعين لهم إن شاء النه الهاء بإحسان

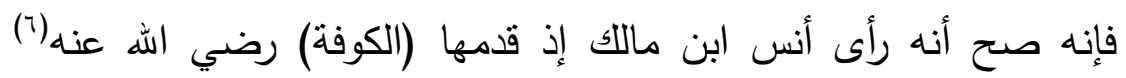

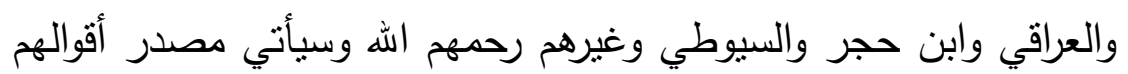
قربياً إن شاء الله تعالى وانى

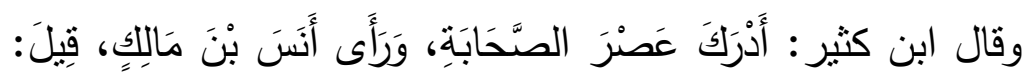

وَغَغَيْرَهُ...

وهناك كثيرون آخرون أثنتوا هذه الروئة قال الإمام عبد الحي

اللكنوي: اختلف العلماء في كون أبي حنيفة تابعياً بعدما اتفقوا على أنها لأنه

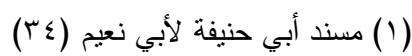

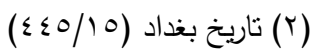

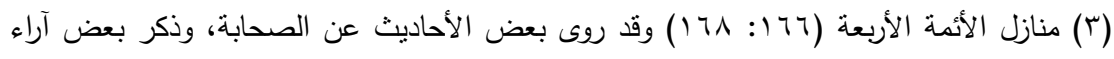

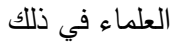

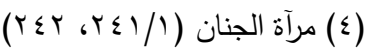

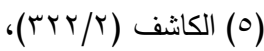

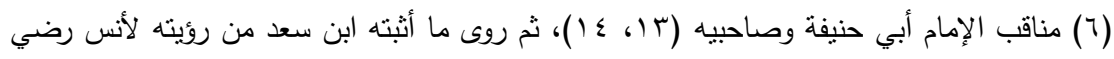

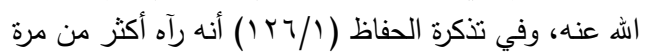

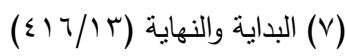


أدرك زمن الصحابة، فمنهم من نفاه، وجمع من الثقات أثثبتوه.

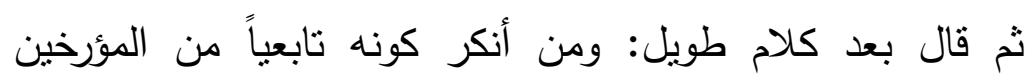
لا يصل في الاعتماد وقوة الحفظ وسعة النظر إلى مرتبة هؤلاء المثتبن،

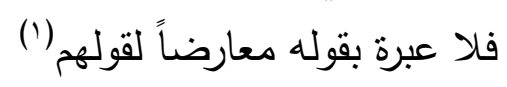

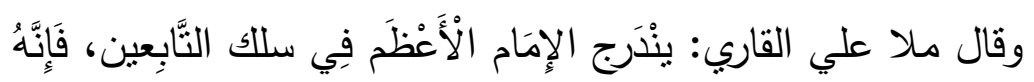

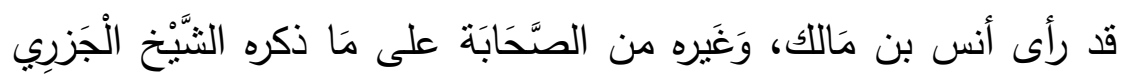

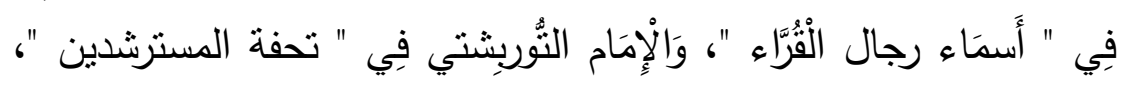

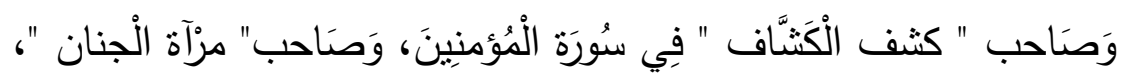

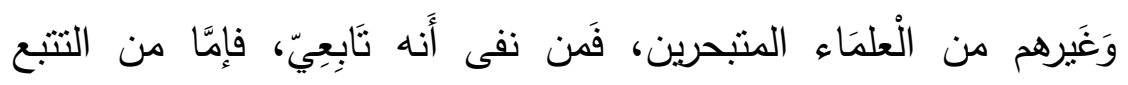

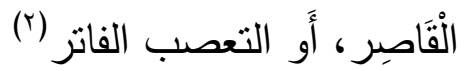

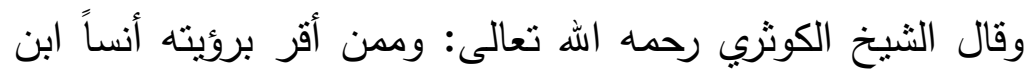

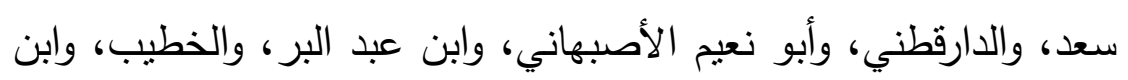

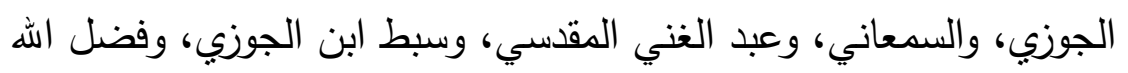

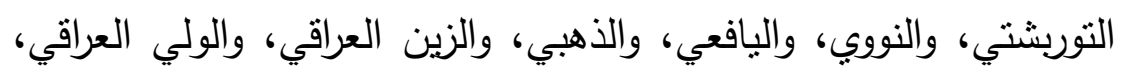

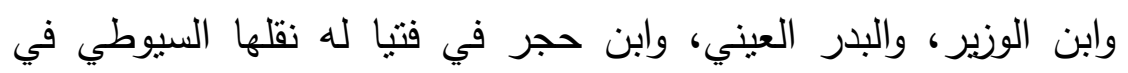

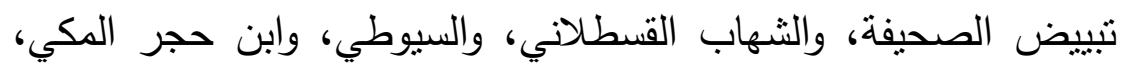
وغيرهم(ن)

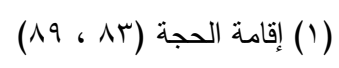

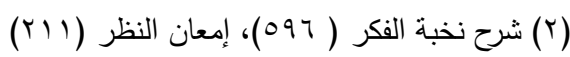

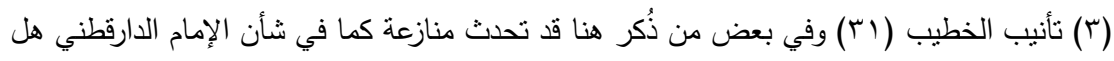

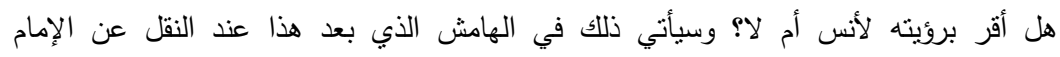

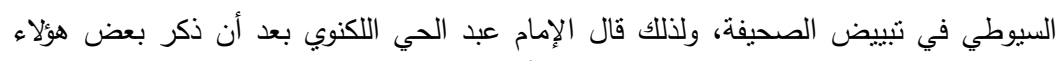

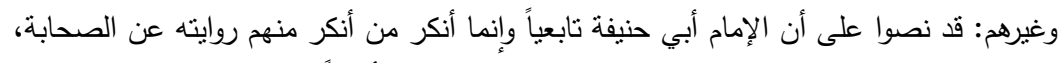

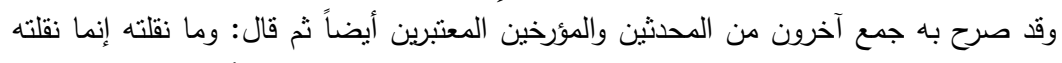

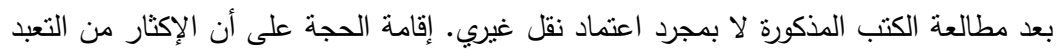

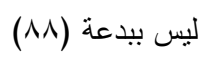




\section{نظرة منيفة إلى المكانة الحديثية للإمام الأعظم أبي حنيفة}

\section{رواية الإمام أبو حنيفة عن الصحابة رضوان الله عليهم:}

قـال الإمـام السـيوطي رحمـهـ الله تعـالى: ألـف الإمـام أبـو معثـر

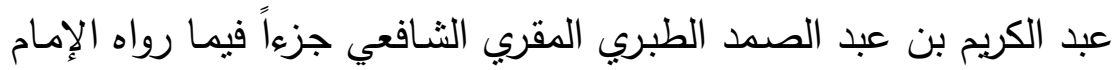
أبو حنيفة عن الصحابة فذكر جماعـة من الصـحابة ثم قال السيوطي: والأحاديث التي أوردها كلها واردة من غير هذا الطريـق لكن قال حمزة

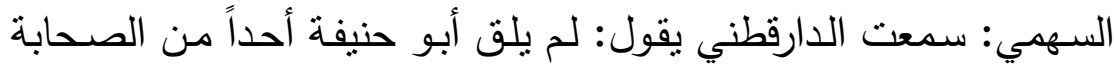

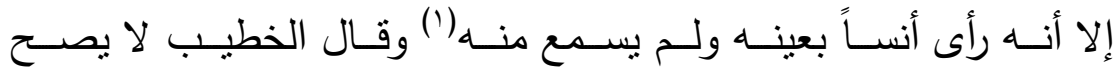
لأبي حنيفة سماع من أنس (r) ووققت على فنيا رفعت إلى الثيخ ولي الدين العراقي صورتها: هل روى أبو حنيفة عن أحد من أصحاب النبي

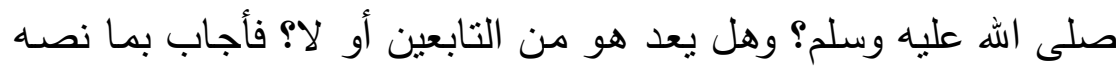
الإمام أبو حنيفة لم يصـح له رواية عن أحد من الصحابة، وقد رأى أنس لهن

(1) هكذا نقل الإمام السيوطي عن الإمام الدارقطني من رواية حمزة السهمي، والذي في المطبوع من

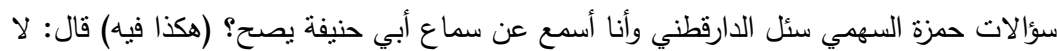

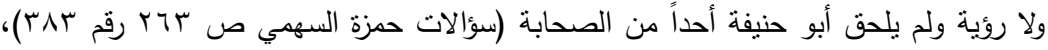

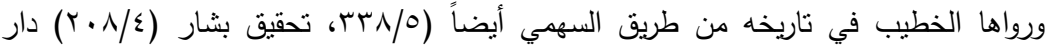

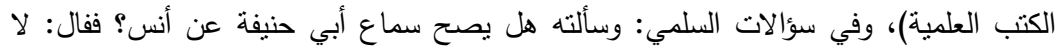

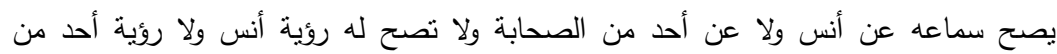

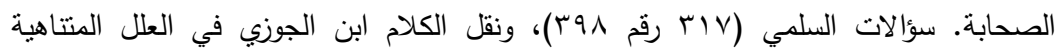

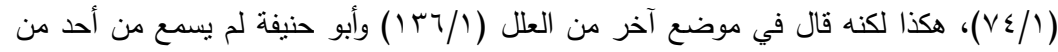

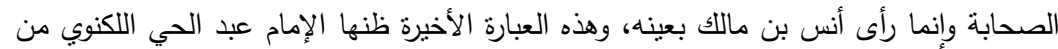

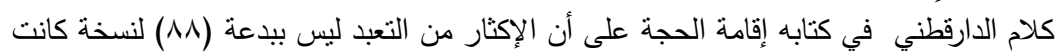

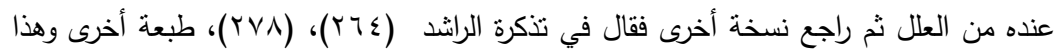

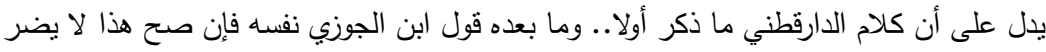

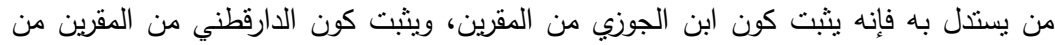

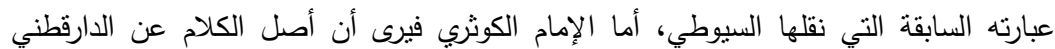

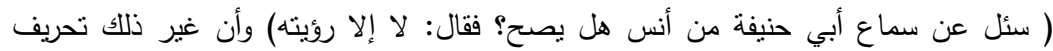

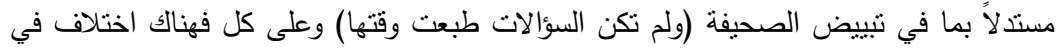

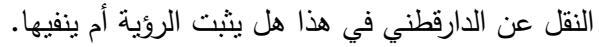

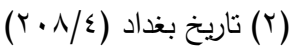


بن مالك، فمن يكتف في التابعي بمجرد رؤيسة الصـحابي يجعلـه تابعياً، ومن لا يكتف بذلك لا يعده تابعياً

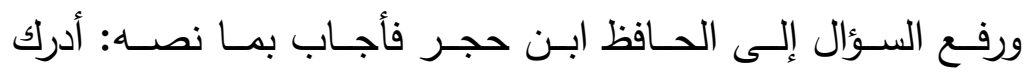

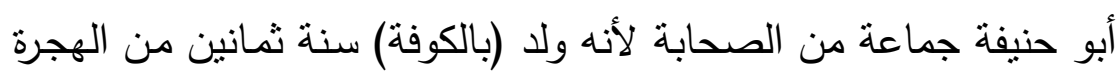

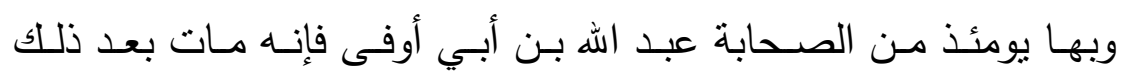
بالاتفاق، وبالبصرة أنس بن مالك ومات سنة تسعين أو بعدها، وقد أورد

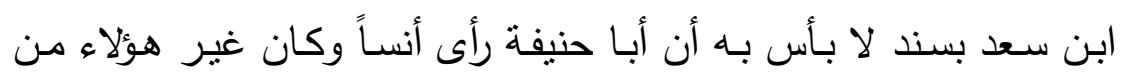

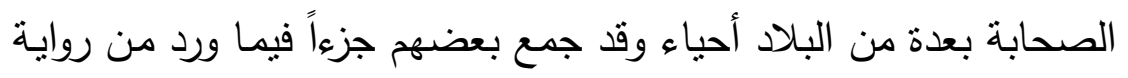

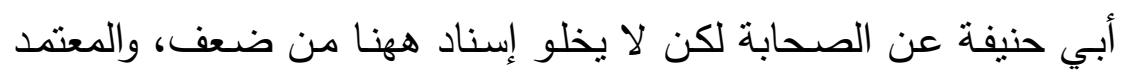

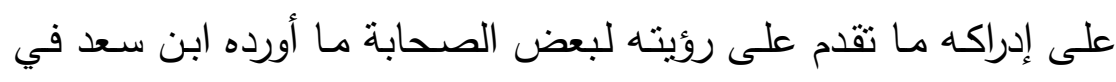

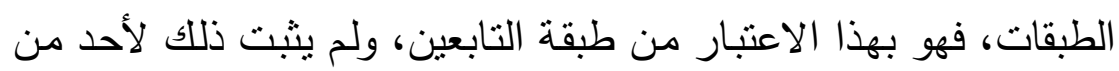

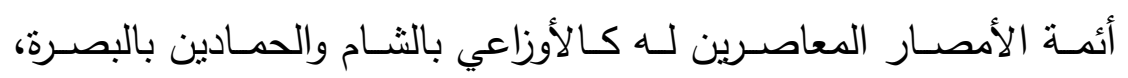

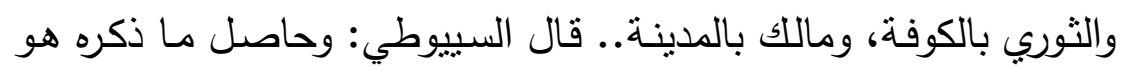
وغيره الحكم على أسانيد ذلك بالضعف وعدم الصحة لا بالبطلان وحينئذ فسهل الأمر في إيرادها، لأن الضعيف يجوز روايته ويطلق عليه أنه وارد كما صرحوا (') وخلاصة هذا الكلام أن الأئمة اتفقوا على رؤية الإمام أبي حنيفة لبعض الصحابة الكرام رضي الله عنهم، واختلفوا في روايته عنهم ومن الهن نفى سماعه من الصحابة حكم أسانيد هذه الأحاديث بالضعف ولم يحكم عليها بالبطلان وفرق بين الضعيف والباطل. ومما يؤيد هذا الكلام قول الإمام ابن كثير في البداية والنهاية في

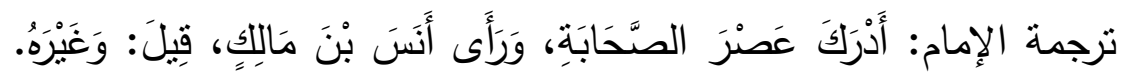

(1) (1) تبيض الصحيفة (ع م، مب) 


\section{نظرة منيفة إلى المكانة الحليثية للإمام الأعظم أبي حنيفة}

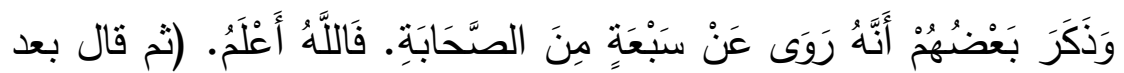

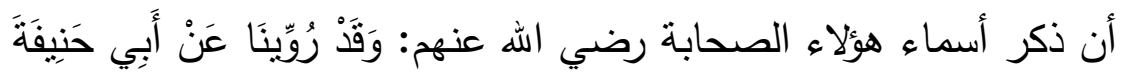

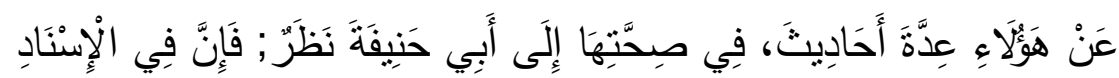

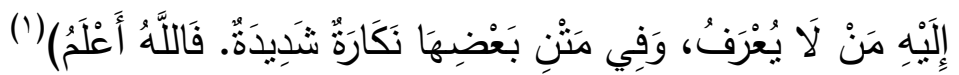

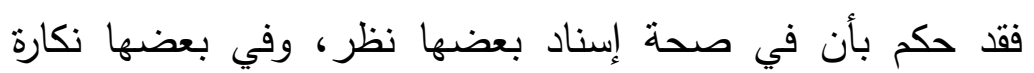

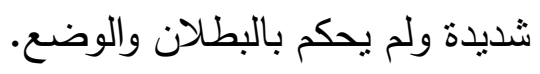
بل زاد البعض فحكم بالصحة أو الحسن، قال الكردري في مناقبه: فالحاصل أن جماعة من المحثثن أنكروا ملاقاته مع الصحابة وأصحابه

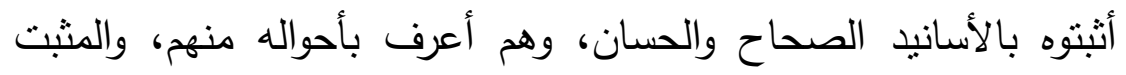

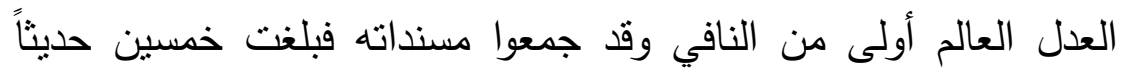

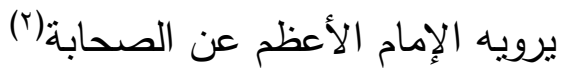

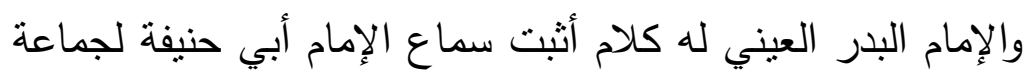

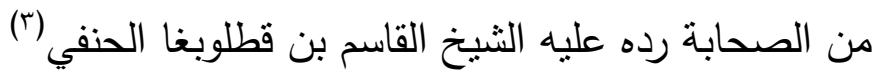

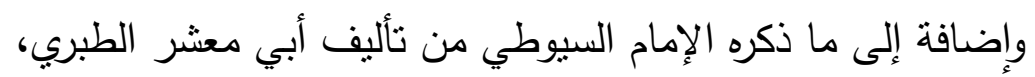

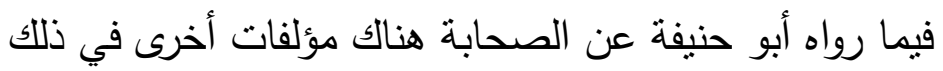

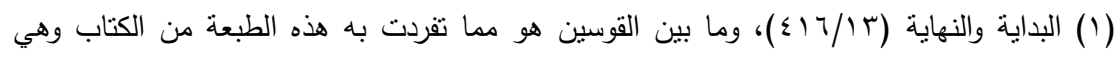

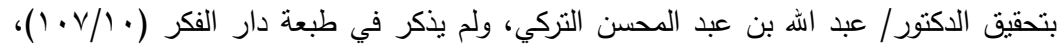

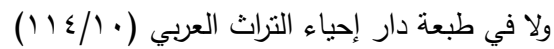

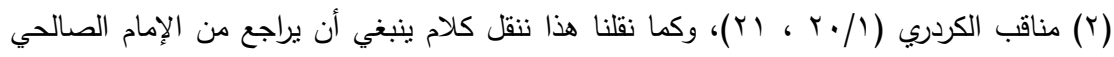

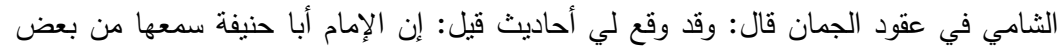

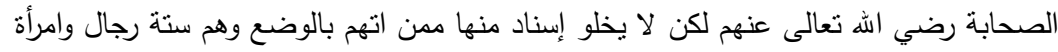

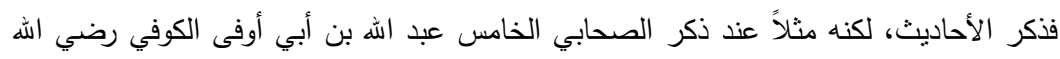

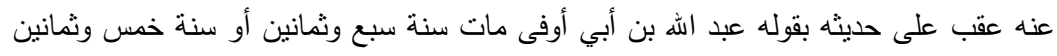

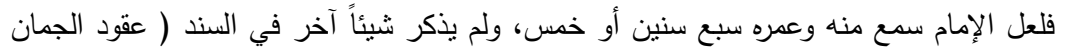




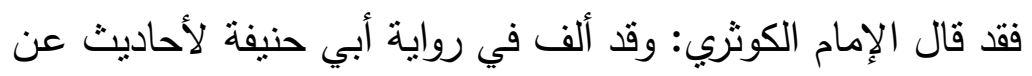

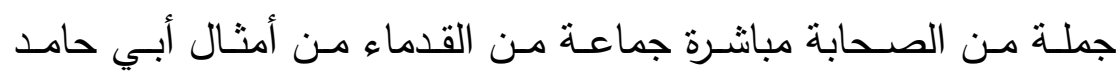

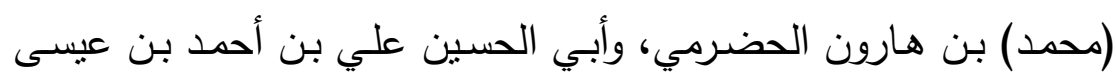

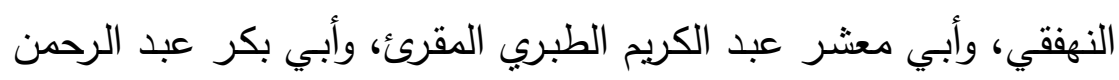

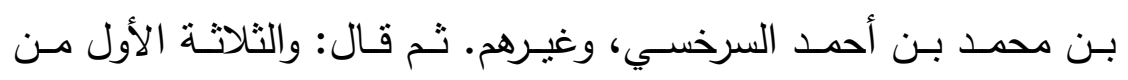

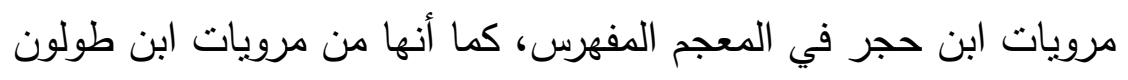

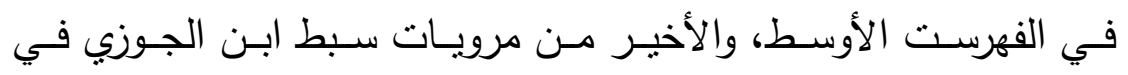

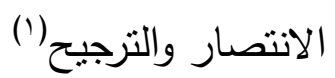
وقد سبق عن الإمام السيوطي أنه قال: وخلاصة ما (ذُكِرِ) الحكم على أسانيد ذلك بالضعف وعدم الصحة لا بالبطلان الإم الصنان

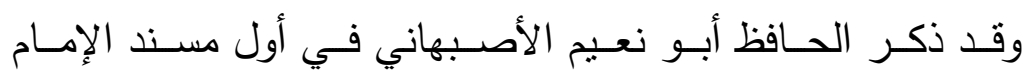

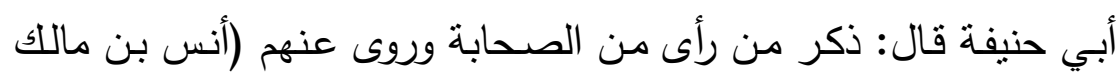

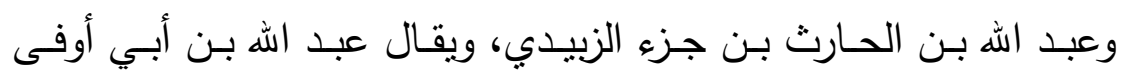

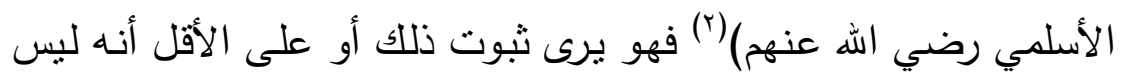
بباطل قال الخوارزمي في جامع المسانيد: اتفق العلماء على أنه روى عن الصحابة وإن اختلفوا في عددهم في جالت.

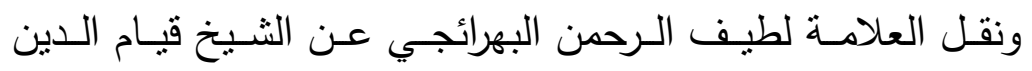
عبد الباري الأنصاري في التعليق المختار على كتاب الآثار للإمام محمد التهد

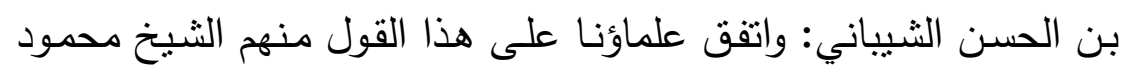

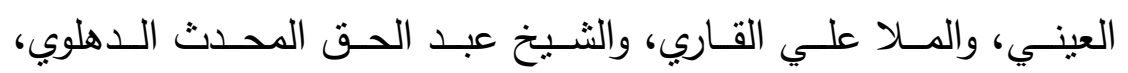

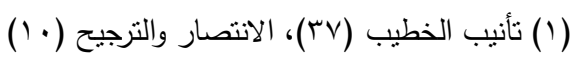

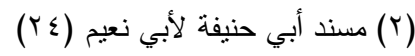

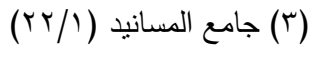




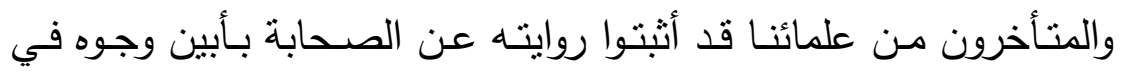

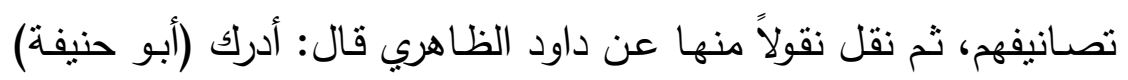

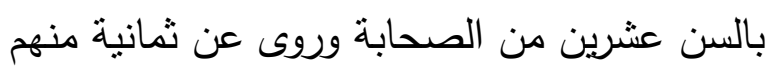

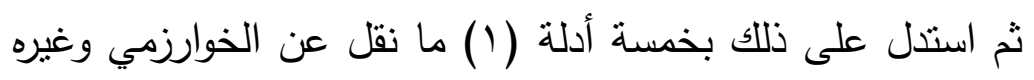

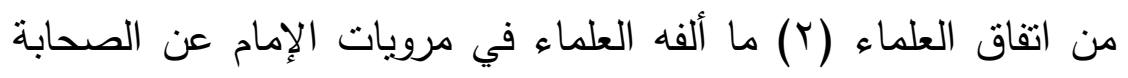

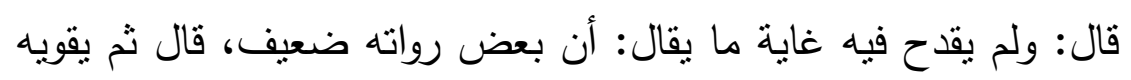

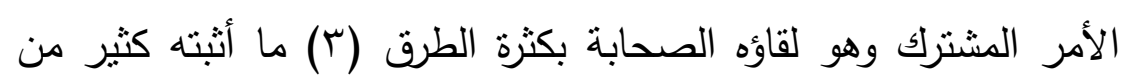

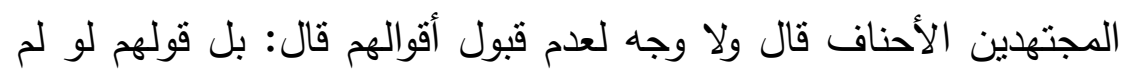

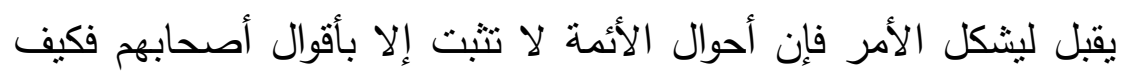

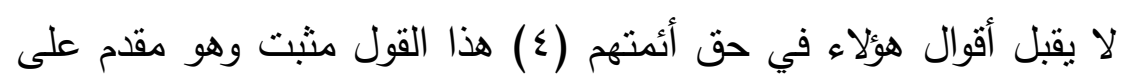

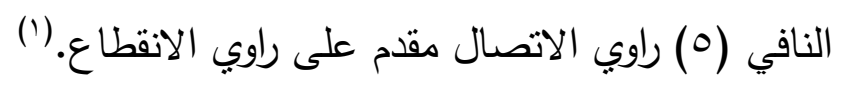
وبهذا يتبين أن إثبات أو نفي سماعه من الصال الصحابة بعد إنبات رؤيته لهم لم يصدر عن تعصب وحقد في الكثير من أحواله فهذا البدر العيني

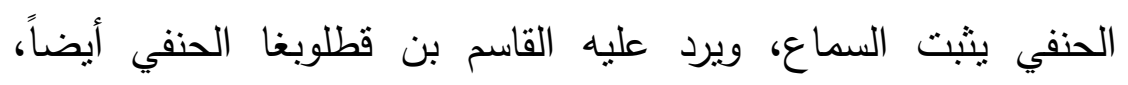
والحافظ ابن حجر الهيتمي (الثافعي) يحاكم بينهما فيثبت رؤيته لأنس

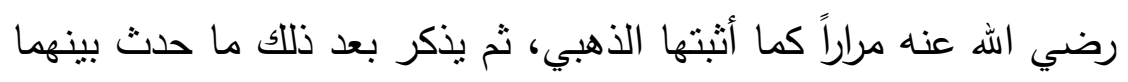

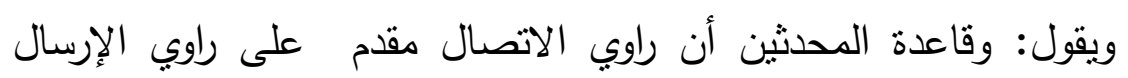

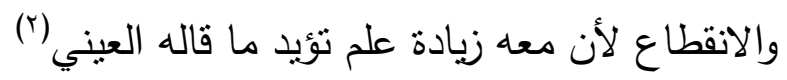

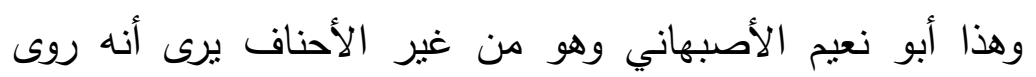

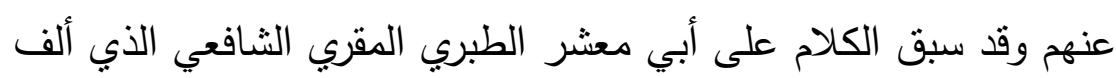

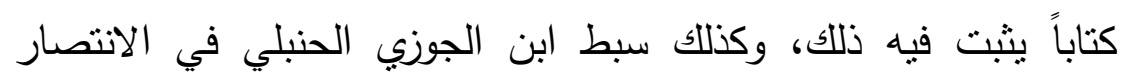

$$
\begin{aligned}
& \text { (1) الأحاديث السبعة عن سبعة من الصحابة ( • 1 1، 17 1 ) بتصرف واختصار }
\end{aligned}
$$

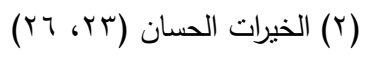


والترجيح يقول: الباب الرابع ذكر من لقي من الصحابة وروى عنه(1) البحث الثالث: شيوخه ورحلاته

كثرة المشايخ وتنوعهم

ذكر المزي في التهذيب ما يزيد على السبعين من شيوخ الإمام

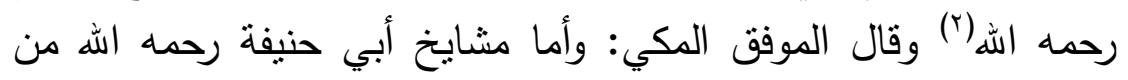

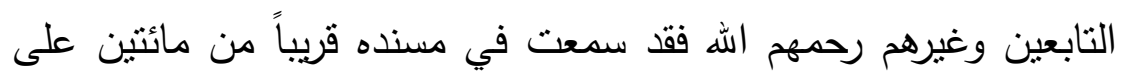

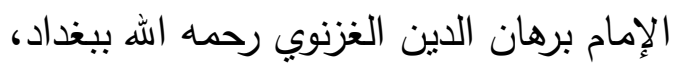

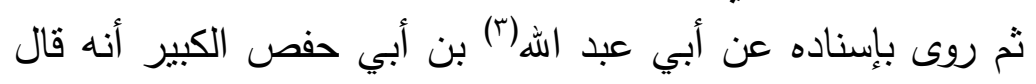

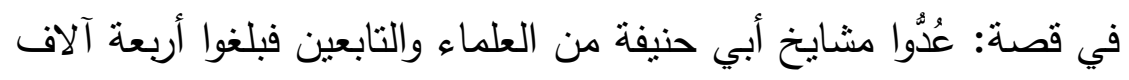

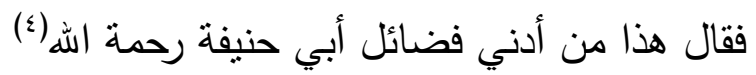

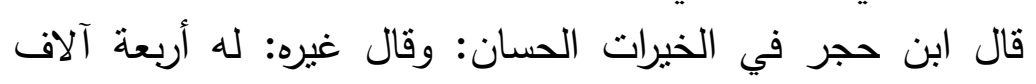

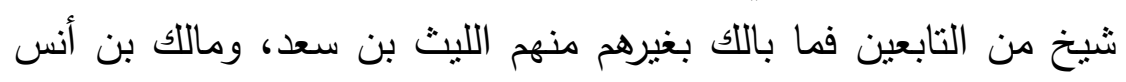

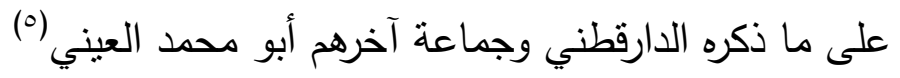

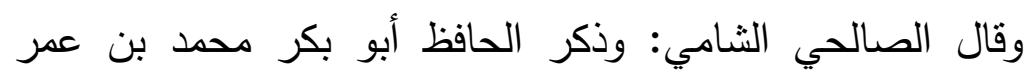
الجعابي في كتابه الانتصار كثيراً من مشايخ الإمام أبي حنيفة.. ثم قال:

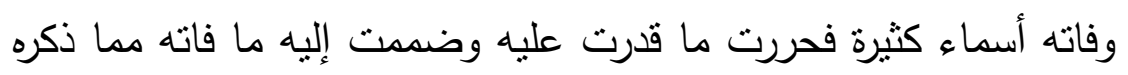

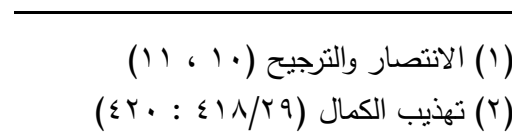

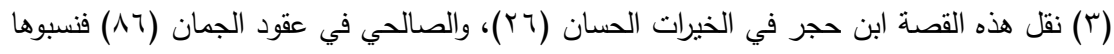

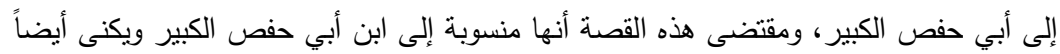

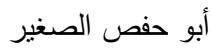

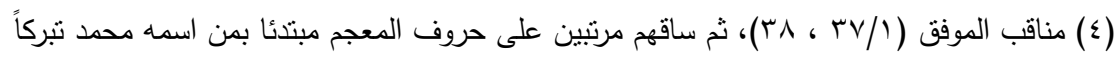

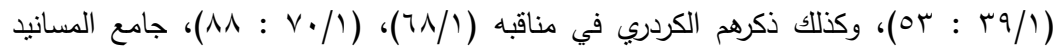

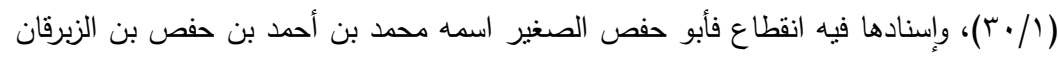

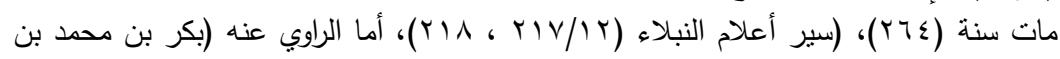

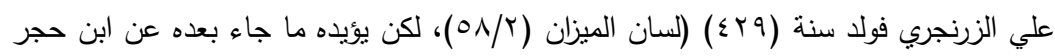

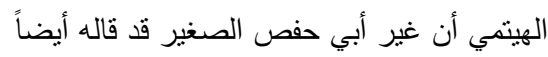

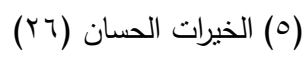


أبو محمد الحارثي، وأبو المؤيد الخوارزمي، والكردري، وأبو محمد العيني وغيرهم فذكر ما يزبد على المائتين (')

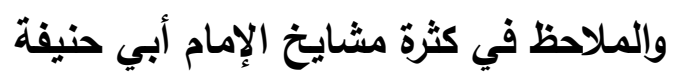

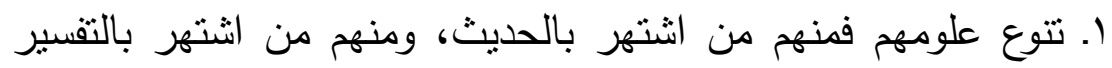

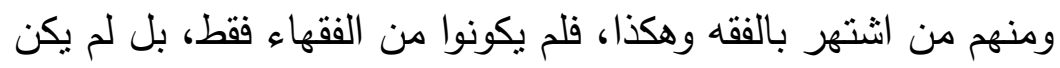

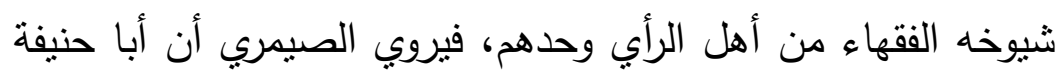

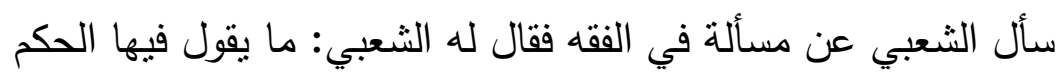

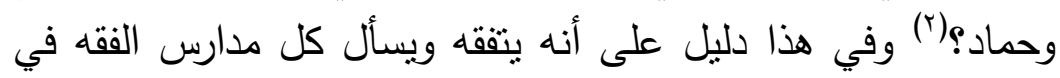
عصره وأنه كان معروفاً بذلك حتى يسأله الثعبي عما يقول حماد بن انه أبي سليمان والحكم في هذه المسألة r. تتوع فرقهم، فالعراق كان فيه من الثيعة الكثير وهم طوائف وفرق وقد

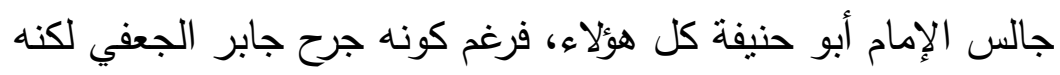

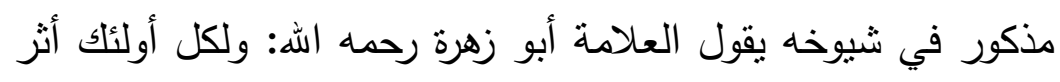
في فكره، وإن لم يعرف أنه نزع منازع هؤلاء إلا في محبته للعترة

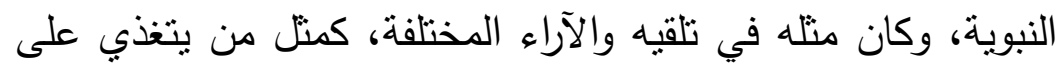

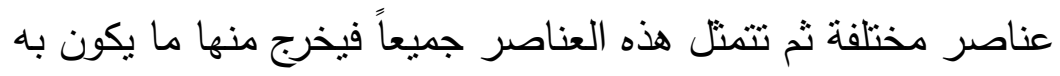
قوام الحياة، وكذلك كان أبو حنيفة يأخذ من كل هذه العناصر ثن ثناه يخرج منها بفكر جديد ورأي قويم لم يكن من نوعها، وإن كان فيه

خيرها(r)

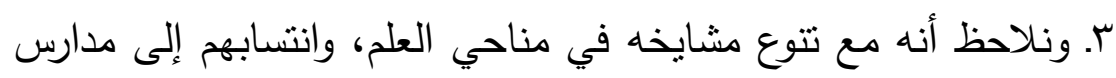

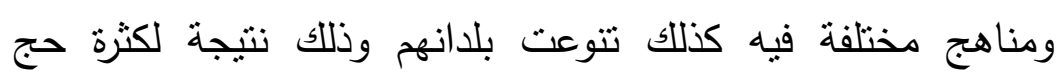

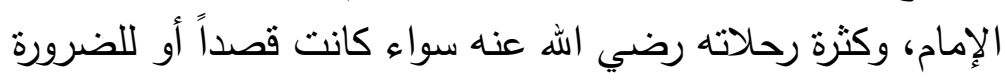
فهو قد سمع بمكة من عطاء بن أبي رباح وغيره ومات عطاء سناء سنة

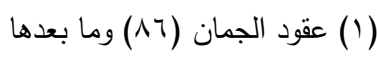

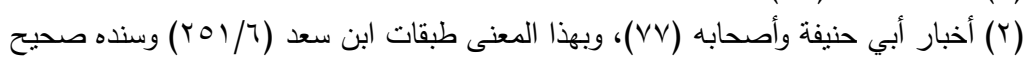

$$
\begin{aligned}
& \text { (Y) أبو حنيفة حياته آراؤه وفقهه (VY) }
\end{aligned}
$$




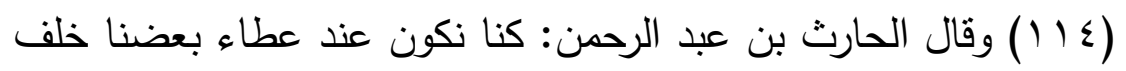

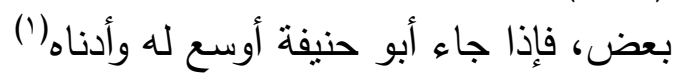

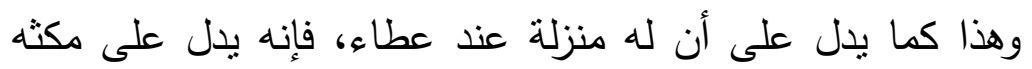
معه الزمن الطويل حتى عرف قدره ومنزلته، ويدل على وجوده بمكة هذا

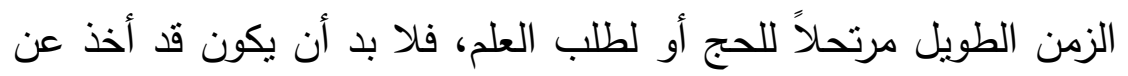
غير عطاء ثم مكث بمكة بعد ذللك ما يقرب من ست سنوات (من سنة .باء

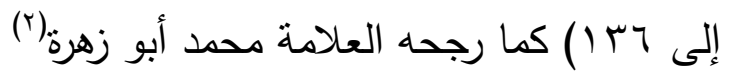

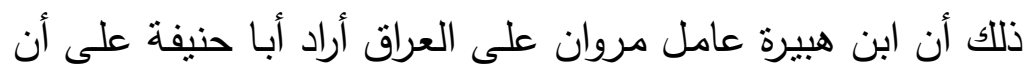

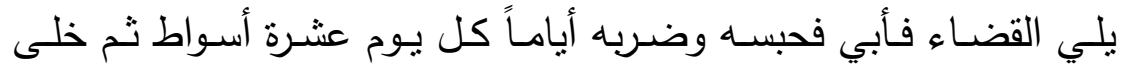

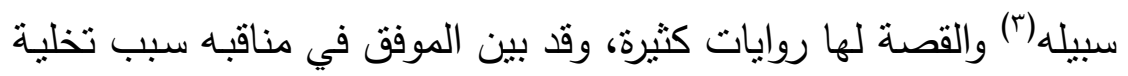
سبيل أبا حنيفة أنه خيف عليه أن يقتل من شدة الضرب فقال ابن هبيرة:

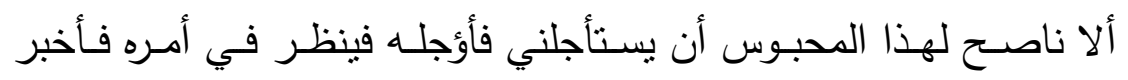
أبو حنيفة بذللك فقال: دعوني أستشير إخواني وأنظر في ذلك فأمر ابن هبيرة بتخلية سبيله فركب دوابـه وهرب إلى مكة وكان هذا في سنة مائة

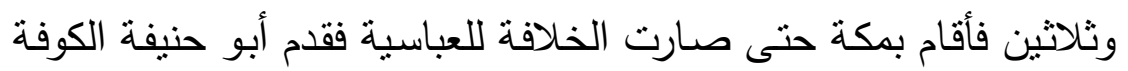

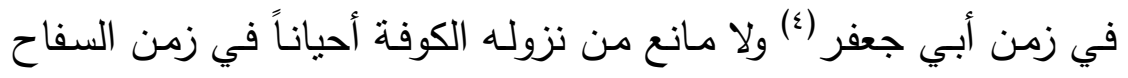

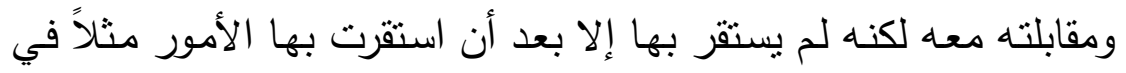
زمن المنصور

وقد جاء أن الإمام رحمه الله حج خمساً وخمسين حجة، قال الدكتور السباعي: ولا شك أنه كان في جميعها يجتمع بالعلماء وبدارسهم(ْ) فهو

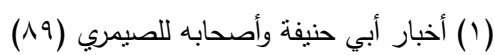

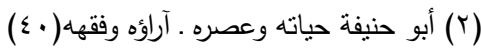

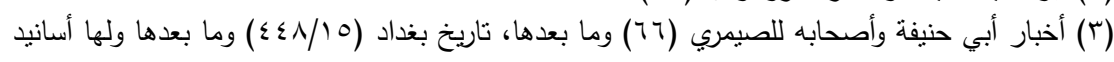
صحيحة

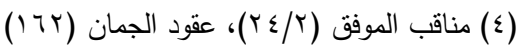
(0) لسان الحكام هامش معين الحكام لابن الثحنة (Yv)، (1)، فقه أهل العراق وحديثهم (10)، السنة ومكانتها 
هكذا تقربياً يحج كل عام وقد يراد بذلك الكثرة مع المكث عدة سنوات

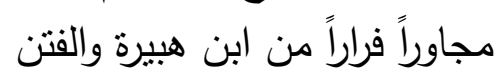

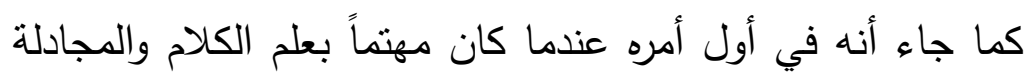

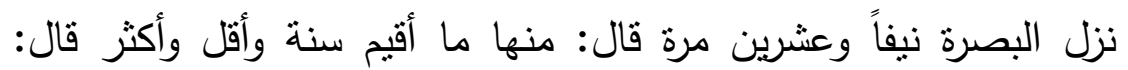

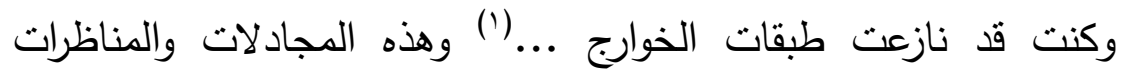

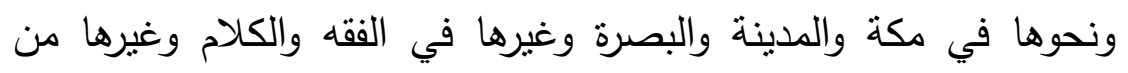

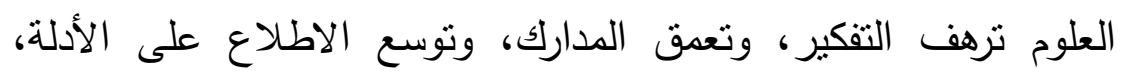

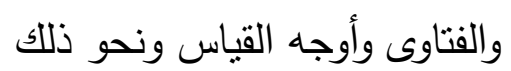

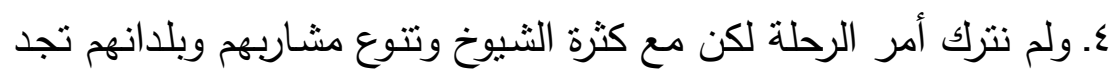

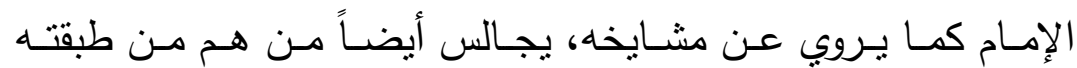

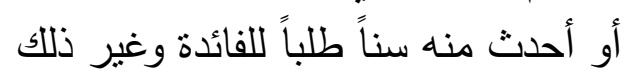

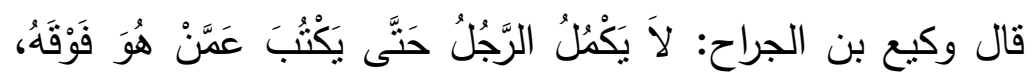

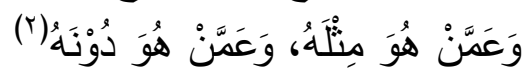

قال عبد العزيز الدراوردي: رأيت أبا حنيفة ومالك برالك بن أنس في مسجد رسول الله صلى الله عليه وسلم بعد العشاء الآخرة وهما يتذاكران

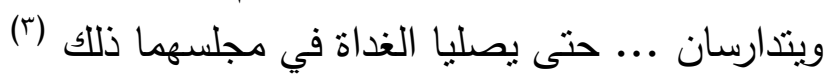
وقال الليث بن سعد: لقيت مالكاً بالددينة فقلت له إني ألي أراك تمسح

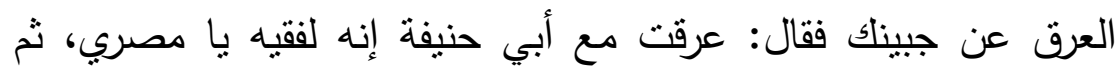
لقيت أبا حنيفة فقلت: ما أحسن قول ذلك الرجل فيلك، فقال: واله ما رأيت

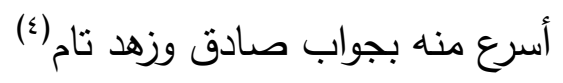

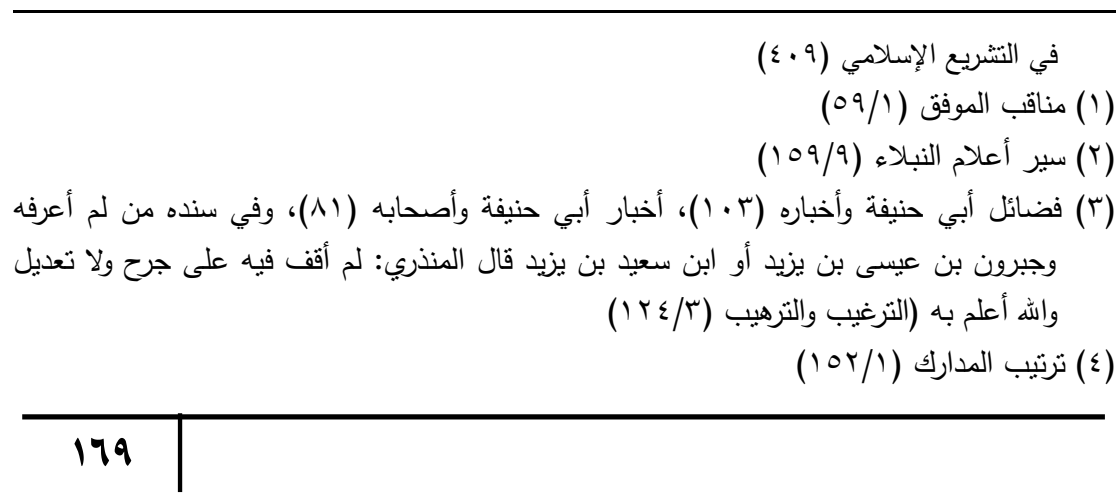


ولما قرأ الإمام الأوزاعي بعض مسائل الإمام مع ابن المبارك وهو

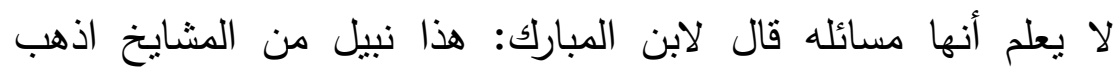

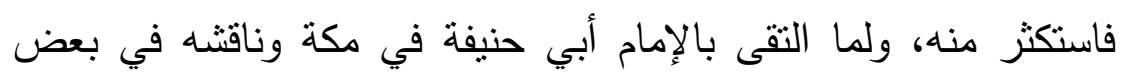

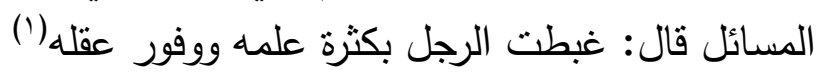

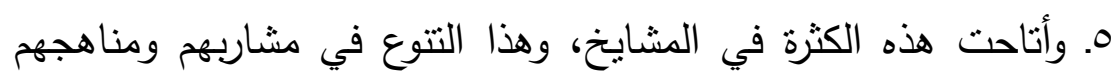

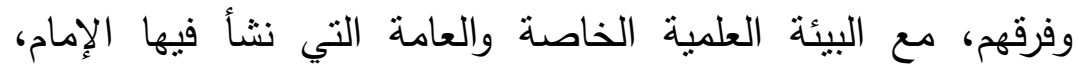

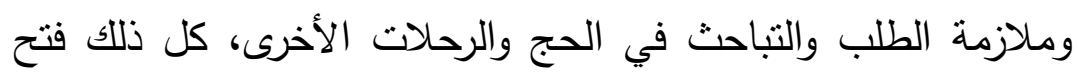

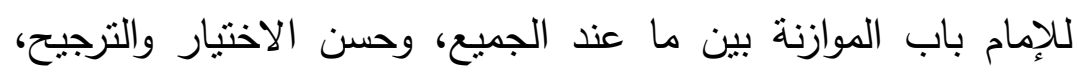

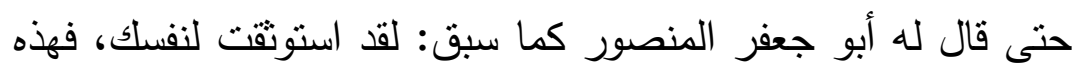

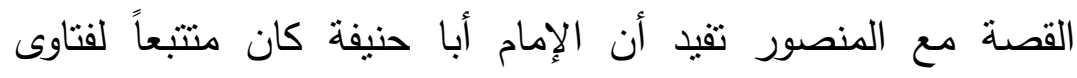

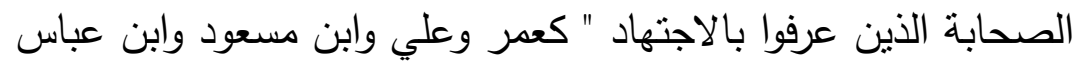

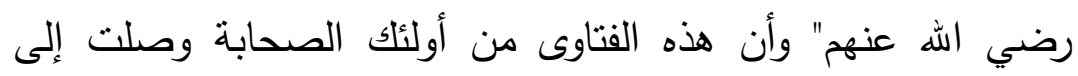
الإمام عن التابعين رضوان الله عليهم ودراسة هذه الفتان الفتاوى تقيد في الفي الفي

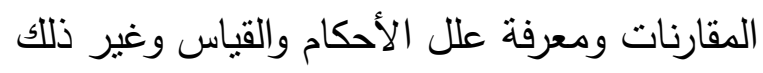

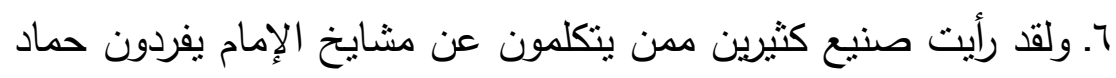

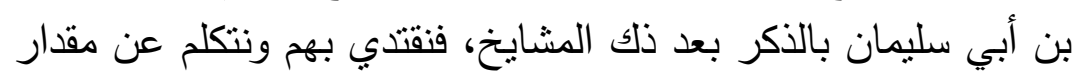

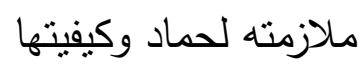

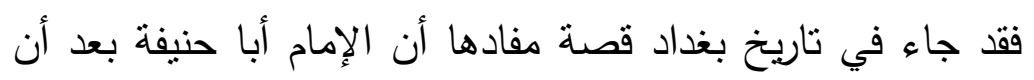

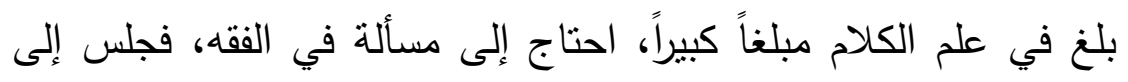

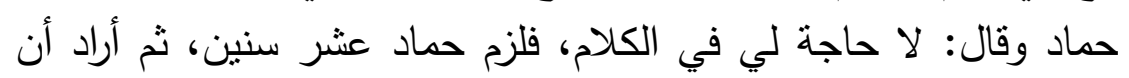

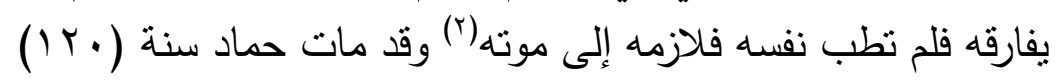
وعند العجلي في الثقات قال أبو حنيفة: قدمت البصرة فظنست أنس أني

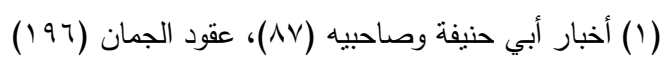

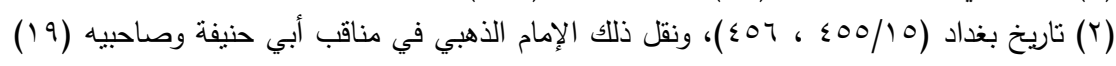

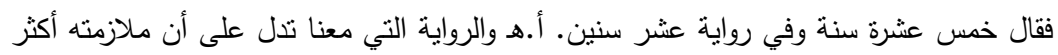

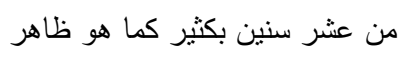




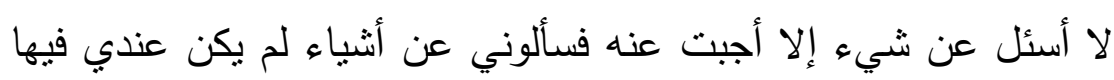

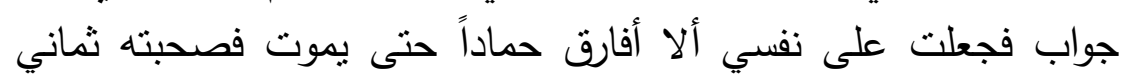
عشرة سنة (1)

فمفاد القصنين على ذلك أنه لازم حماد أكثر من ثماني عشرة سنة

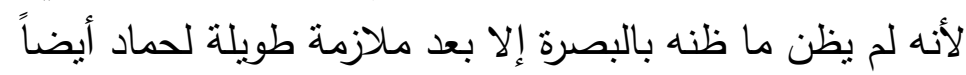

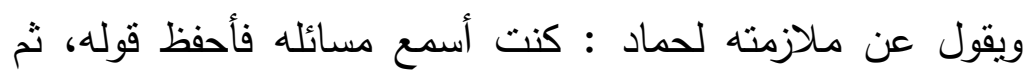

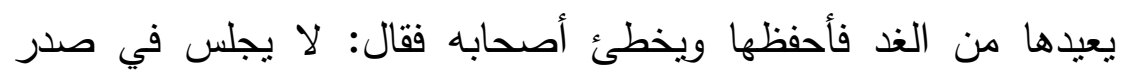

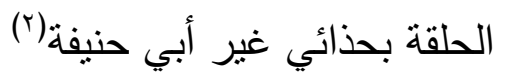

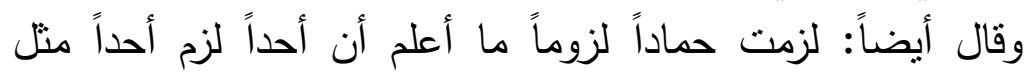

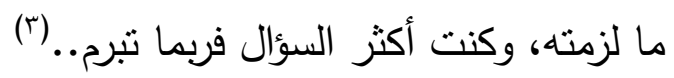

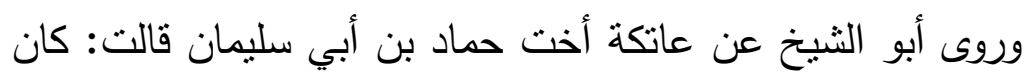

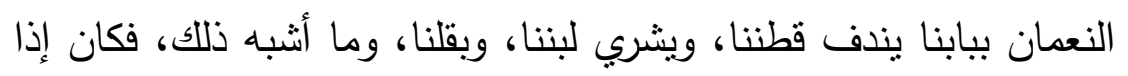

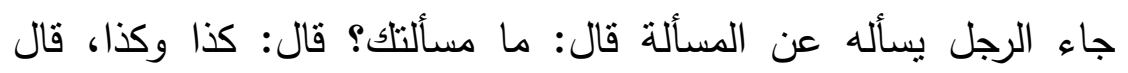

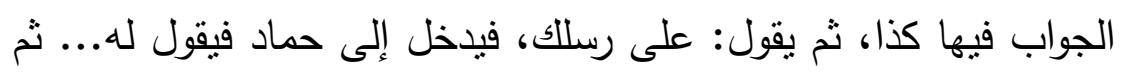

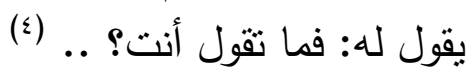

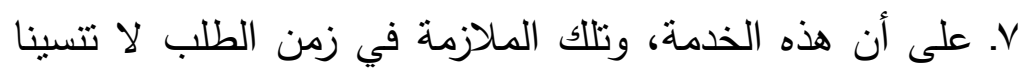

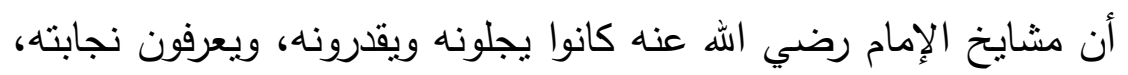

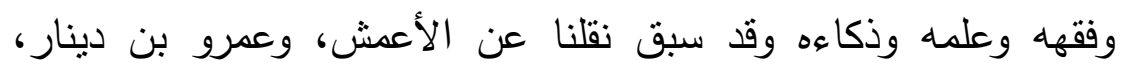

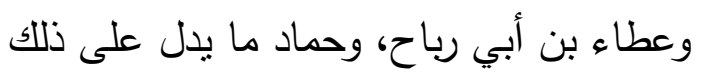

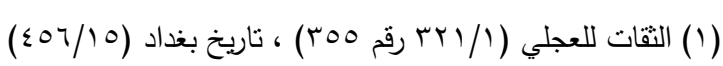

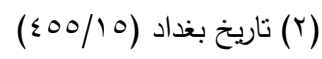

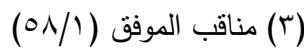

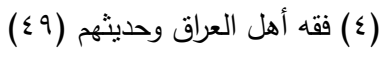




\section{البحث الرابع}

\section{مدرسة الإمام أبي حنيفة (تلاميذه، ومنهجه معهم)}

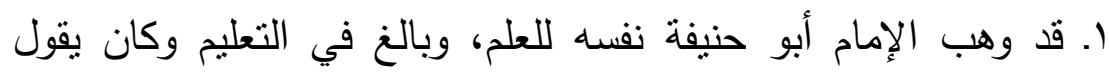

لتلاميذه: أنتم مسار قلبي وجلاء حزني (')

وكان يكرم تلاميذه قال حجر بن عبد الرحمن الحضرمي: ما رأى

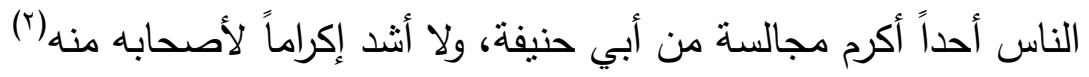

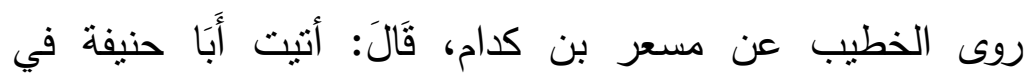
مسجده، فرأيته يصلي الغداة، ثُمَّ يجلس للناس في العلم إلى أن يصلي الظهر ، ثم يجلس إلى العصر ، فإذا صلى العصر جلس إلى المغرب، فإذا صلى المغرب جلس إلى أن بصلي العثاء، فَقُلْتُ في نفسي: هَذَا الرجل في هَذَا الثخل مَتَى يفرغ للعبادة؛ لأتعاهدنه الليلة، قَالَ: فتعاهدته، فَلَمَّا

هدأ النَّاس، خرج إلى المسجد فانتصب للصلاة إلى أن طلع الفجر ...(־)

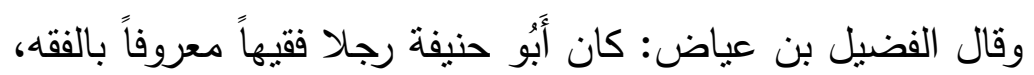

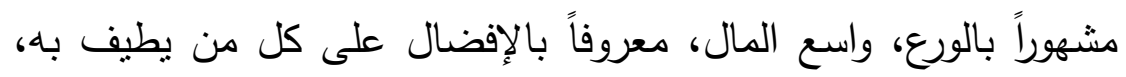
صبوراً على تعليم العلم بالليل والنهار، حسن الليل كثير الصمت، قليل الكلام حتى ترد مسألة في حلال أو حرام، فكان يحسن أن بدل على بلى الحق، هاربا من مال السلطان. زاد في رواية عنه: وكان إذا وردت عليه مسألة فيها حديث صحيح اتبعه، وإن كان عن الصحابة والتابعين، وإلا (r) ناريخ بغداد (YN/

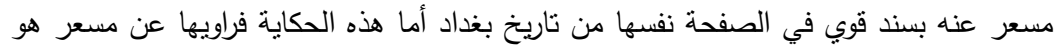
ابن أبي معاذ ولم أعرفه 


\section{نظرة منيفة إلى المكانة الحديثية للإمام الأعظم أبي حنيفة}

قاس وأحسن القياس (') r. ب. وقد كثر عدد تلاميذه

r. وكانوا أئمة كباراً بلغوا درجة الاجتهاد جعلهم الإمام أبو حنيفة بطريقته في التعليم أصدقاء له ونظراء

ع. وكان انتفاع الناس به وبتلاميذه عظيماً كبيراً

قال الإمـام ابن حجر المكي: الآخذين عنه الحديث والفقه، قيل:

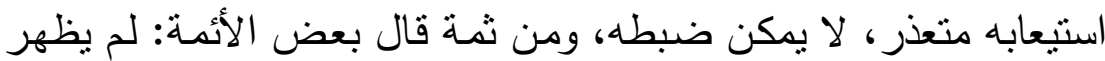

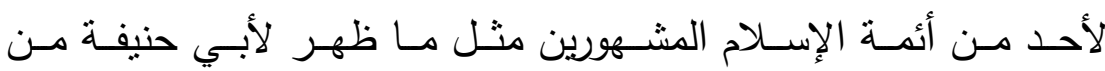
الأصـحاب والتلاميذ، ولم ينتفع العلماء وجميع الناس بمثل ما انتفعوا بـه وبأصـابه في تقسير الأحاديث المشتبهة والمسـائل المستتبطة والنوازل والقضاء والأحكام، جزاهم الله خيراً وقد ذكر منهم بعض منأخري المحدثين

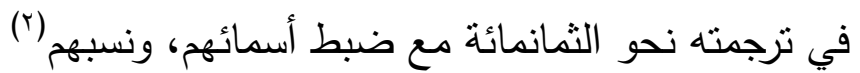
وقال الذهبي: روى عنه من المحدثين والفقهاء عدة لا يحصون من

أقرانه ومن بعدهم (r) - (أ)

وقال الصالحي الثامي: في بعض خصائصه التي اختص بها عن غيره من الأئمة رضوان الله تعالى عليهم أجمعين... السادس: أنه اتفق له

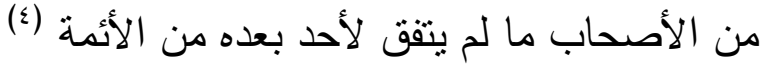

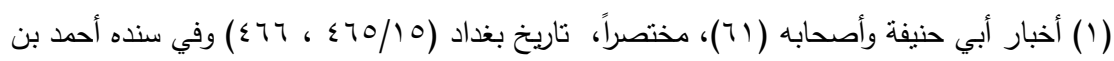

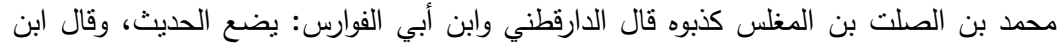
قانع ليس بنقة

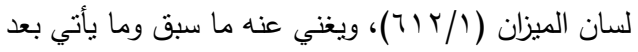

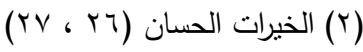

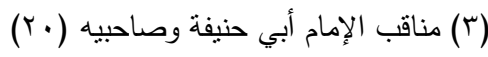

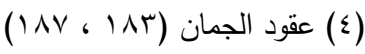


وقال الخوارزمي في جامع المسانيد: النوع السابع من مناقبه

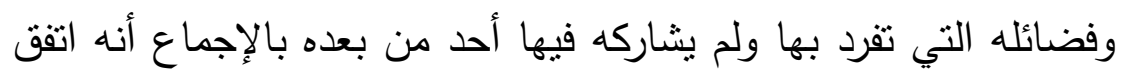
له من الأصحاب ما لم يتفق لأحد من بعده ثم نقل عن قاضي القضاة أبي بكر عنيق بن داود اليماني أنه قال: أيد الله (أبا حنيفة) بالتوفيق

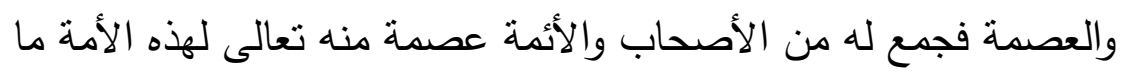
لم يجتمع في عصر من الأعصار في الأطراف والأقطار ثم ذكر عدداً منهم كأبي يوسف ومحمد وزفر ووكيع وابن المبارك وغيرهم (')

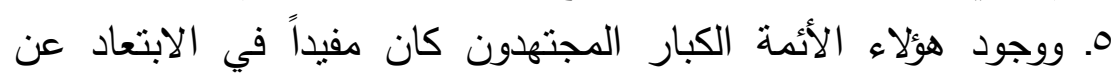
الخطأ عموماً خاصة في الفقه والإفتاء

7. فقد كانوا بتشاورون المسائل ويمحصوها فتخرج أصولهم ومسائلهم وأقوالهم في غاية الإتقان لمكان تشاورهم

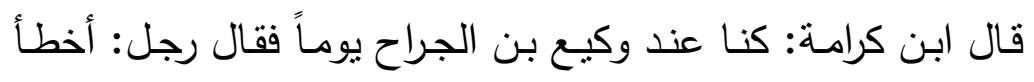

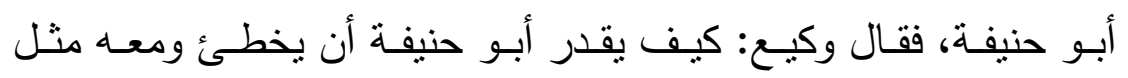
أبي يوسف ومحمد وزفر في قياسهم واجتهادهم، ومتل يحيى بن زكريا بن أبي زائدة وحفص بن غياث، وحبان، ومندل ابنا علي في حفظهم للحديث

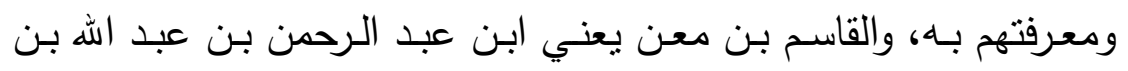

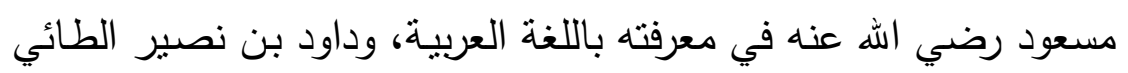

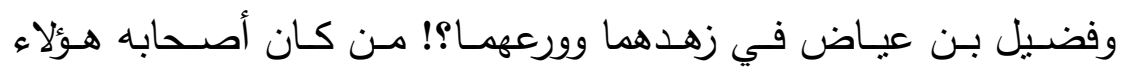

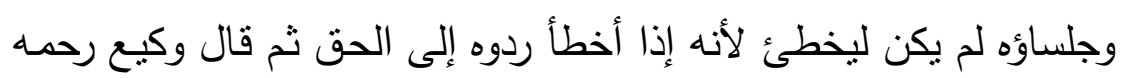

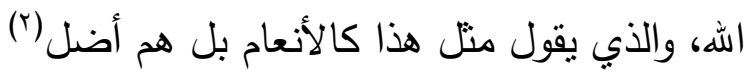

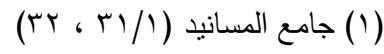

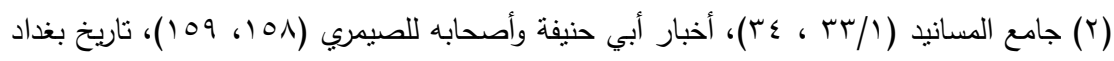

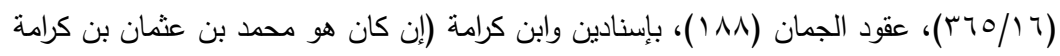

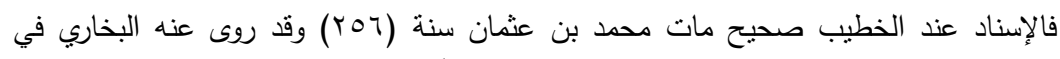

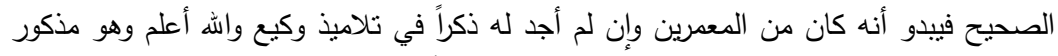

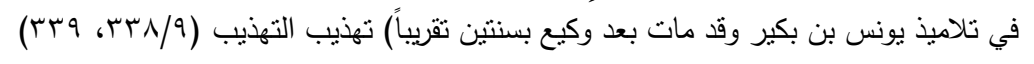




\section{نظرة منيفة إلى المكانة الحليثية للإمام الأعظم أبي حنيفة}

وقال جرير سمت الأعمش وجاء رجل فسأله عن مسألة فقال: عليك بأهل هذه الحلقة، فإنهم إذا وقعت لهم مسألة لا يزالون يديرونها

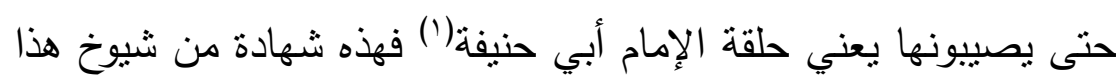

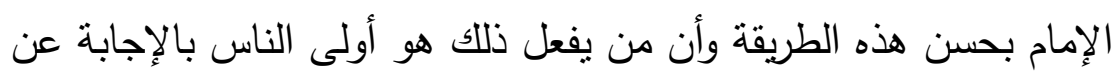

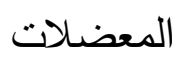

ونقل الخوارزمي عن الإمام شمس الأئمة السايلي أنه قال: اشتهر واستفاض أن أبا حنيفة تلمذ عند أربعة آلاف من شيورخ أئمة التابعين ..

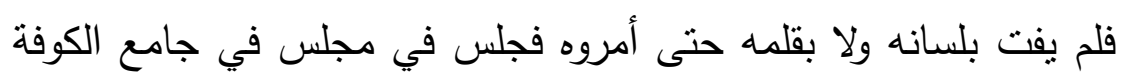

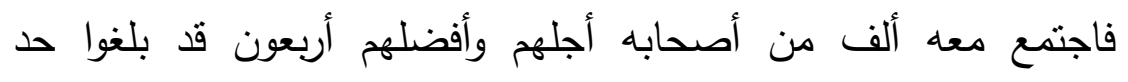

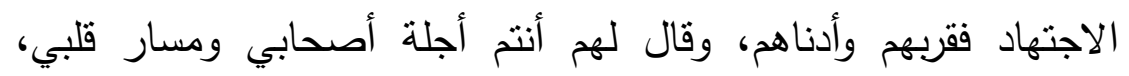
وجلاء أحزاني، وإني ألجمت هذا الفقه وأسرجته لكم فأعينوني .. وكان التهان

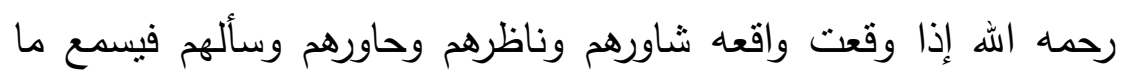

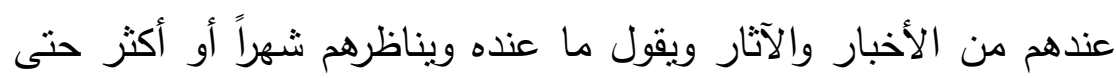

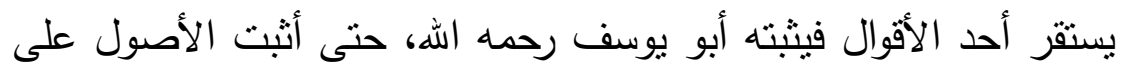

هذا المنهاج شورى لا أنه تقرد بذلك .. ثم استخل بقصة وكيع السابقة (r)

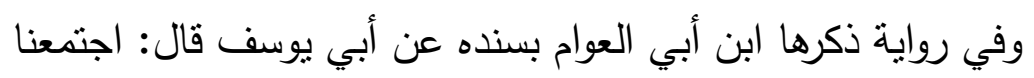

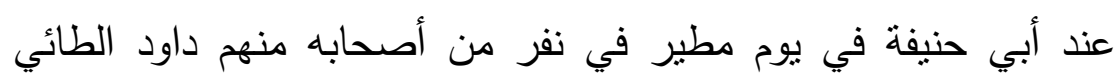

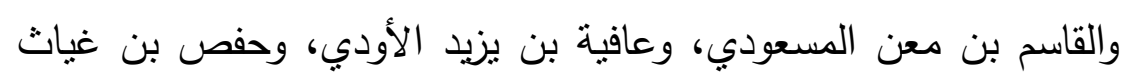

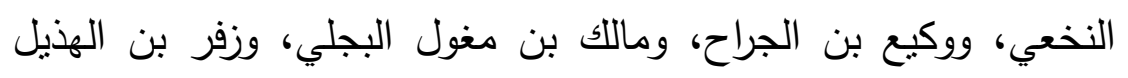

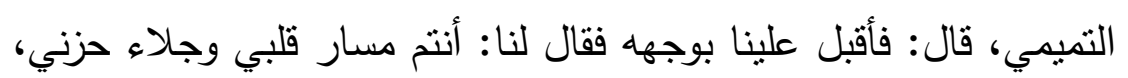

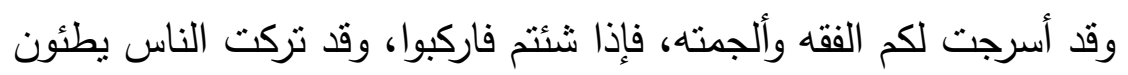


أعقابكم، ويلتمسون ألفاظكم، ما منكم واحد إلا وهو يصلح للقضاء، ومنكم عشرة يصلحون أن يكونوا مؤدبي القضاة، فسألتكم بالله عز وجل، وبقدر

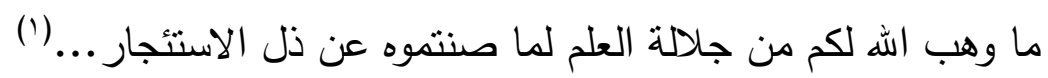
وقـال أبـو يوسـف: كـان أبـو حنيفـة إذا وردت عليـه المسألة قـال: ما عندكم فيها من الآثار فإذا روينا الآثار وذكرنا وذكر هو ما عنده (r)... نظر

يقول الإمام الكوثري رحمه الله: وكان أجلى مميزات مذهب أبي حنيفة أنه مذهب شورى ثلقته جماعة عن جماعة إلى الصحابة

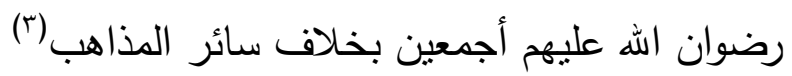
قال المغيرة بن حمزة: كان أصحاب أبي حنيفة الذين دونوا معه الكتب أربعين رجلاً كبراء الكبراء وقال أسد بن الفرات: كان أصحاب أبي حنيفة الذين دونوا الكتب

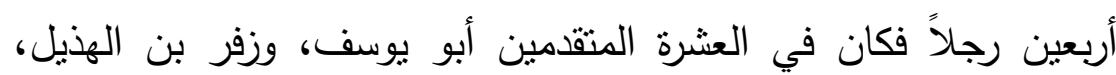
وداود الطائي، وأسد بن عمرو، ويوسف بن خالد السمتي، ويحيى بن زكرياء بن أبي زائدة، وهو الذي كان يكتبها لهم ثلاثثن سنة بـن

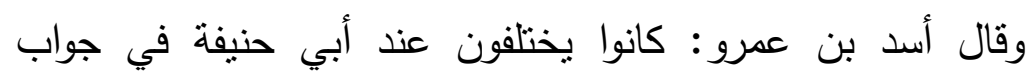
المسألة فيأتي هذا بجواب، وهذا بجواب، ثم يرفعونها إليه ويسألونه عنها فيأتي الجواب من كثب ـ أي من قرب ـ وكانوا يقيمون في المسألة ثناثة

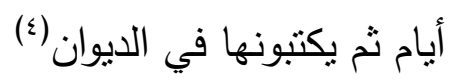

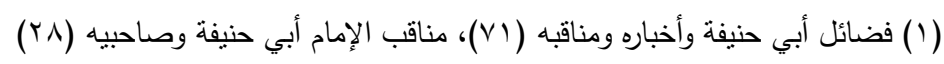

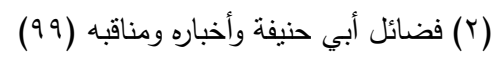
(r) فقه أهل العراق وحديثهم (T) (ب0)

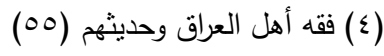




\section{نظرة منيفة إلى المكانة الحديثية للإمام الأعظم أبي حنيفة}

وقال الموفق في المناقب: فوضع أبو حنيفة رحمه الله مذهبه شورى بينهم، لم يستبد به بنفسه دونه، اجتهاداً منه في الدين، ومبالغة في الي النصيحة لله ورسوله والمؤمنين فكان يلقي المسائل مسألة، مسألة، يقلبهم،

ويسمع ما عندهم ويقول ما عنده، ويناظرهم (1)

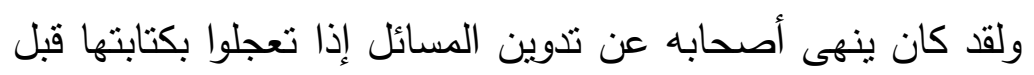
تمحيصها كما يجب، وقد يستدل على ذلك بما قاله لأبي يوسف مرة: ويحك يا يعقوب لا تكتب كل ما تسمع مني فإني قد أرى الرأي اليوم وأتركه غداً...

وقال إسحاق بن إبراهيم: كان أصحاب أبي حنيفة يخوضون معه في المسألة، فإذا لم يحضر عافية (ابن يزيد الأودي) قال أبو حنيفة: لا نرفعوا المسألة حتى يحضر عافية! فإذا حضر عافية ووافقهم قال

أبو حنيفة: أثنتوها، وإن لم يوافقهم قال أبو حنيفة: لا تتبنوها(َ)

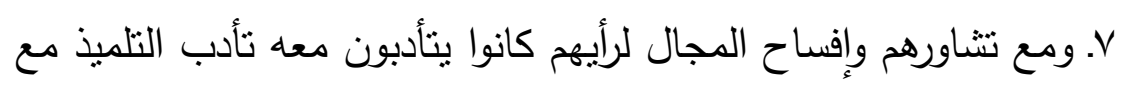
معلمه ويعرفون قدره ويهابونه

قيل للحسن بن زياد: ألست قد رأيت زفر بن الهذيل، وأبا يوسف ونف عند أبي حنيفة؟ قال: بلى، قيل فكيف رأيتهما عنده؟ قال: كعصفورين انقض عليهما بازي(ء) وقال محمد بن الحسن رحمه الله: كان أبو حنيفة رحمه الله يناظر أصحابه في المقاييس، فينتصفون منه فيعارضونه حتى إذا قال:

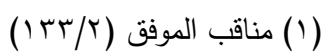

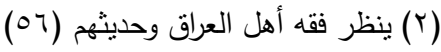

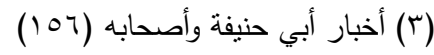

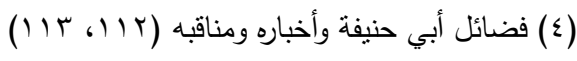


أستحسن. لم يلحقه أحد منهم لكثرة ما يورد في الاستحسان من المسائل

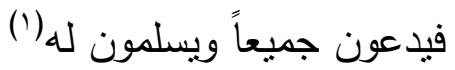

وقد يتجاوز عنهم أحياناً رجاء أن يتعلموا، فال سُفْبَانُ بْنُ عُيَيْنَةَ: "

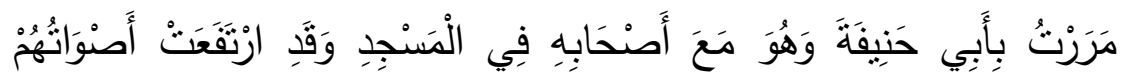

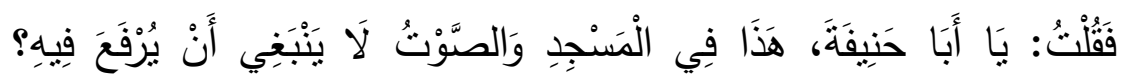

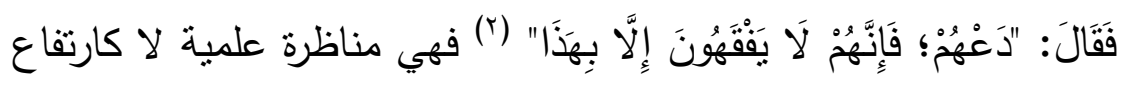
الأصوات في الأسواق ^. وكان مع الجانب التعليمي لا يهمل الجانب التربوي وقد سبق قوله لتلاميذه: ما منكم واحد إلا وهو يصلح للقضاء، ومنكم عشرة يصلحون أن يكونوا مؤدبي القضاة، فسألتكم باله عز وجل، وبقدر ما وهب الهه لكم من جلالة العلم لما صنتموه عن ذل الاستئجار، وإن بُلي أحد منكم بالدخول في القضاء فعلم من نفسه خربة سترها الله عز وجل عن العباد لم يجز قضاؤه، ولم يطب له رزقه، وإن كانت سريرته منل علانيته جاز قضاؤه وطاب له رزقه، فإن دفعته ضرورة إلى الدخول فيه فلا يجعلن بينه وبين الناس حجاباً، وليصلي الصلوات الخمس في مسجده وينادي عند كل صلاة من لله

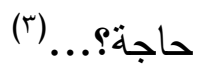

يقول العلامة أبو زهرة: كان يتعهدهم بالنصيحة خصوصاً لمن كان

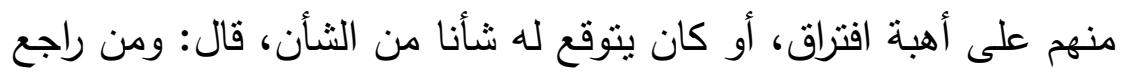
المناقب للموفق وابن البزازي وجد فيهما الثيء الكثير من الوصايا

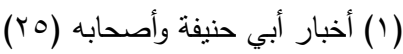

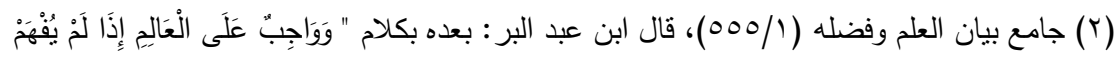

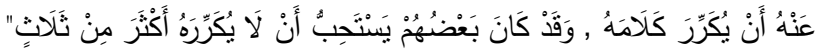

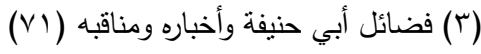




\section{نظرة منيفة إلى المكانة الحديثية للإمام الأعظم أبي حنيفة}

المحكمة الرائعة (1)

الفصل الثالث

بيان منزلة الإمام في علم الحديث من خلال ثناء العلماء عليه

$$
\text { وقد جعلته خمسة بحوث }
$$

الأول: وصفه بأعلى درجات التعديل

الثاني: ما جاء من التعديل وبيان عظيم منزلته في علم الحديث غير ما تقدم

الثالث: ما جاء تعديلاً للإمام ودفاعاً عنه إجمالاً الرابع: أشياء يستدل بها على عظيم منزلة الإمام في علم الحديث الخامس: بيان كثرة حديثه والمسانيد التي جمعت عنه

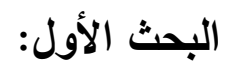

وصفه بأعلى درجات التعديل

وهي ما جاء بأفعل التفضيل، وما يجري مجراه

قال الحافظ ابن حجر: ومن المهم معرفة مراتب التعديل وأرفعها

الوصف بما دل على المبالغة فيه وأصرح ذلك التعبير بأفعل كأوثق الناس

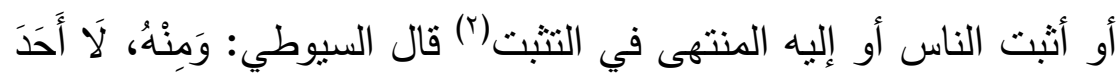

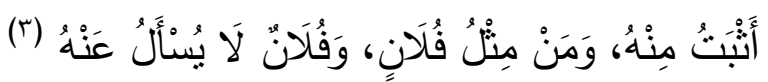

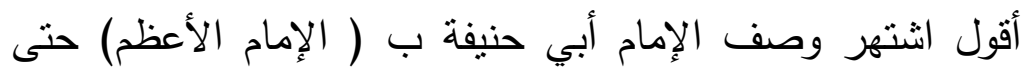

صار كأنه علم عليه من غير إنكار وهو وصف يشمل كونه أعظم في كل شيء ومنه الحديث وقد وصفه علماء كثيرون بطرق مختلفة بصفات

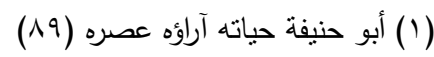

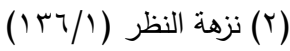

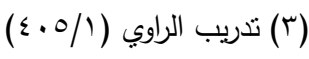


كثيرة تزبد على عشرة صفات أنه كان في هذه الصفات الأفضل على

الإطلاق وبعضهم قيدها بالبلد أو الزمان (')

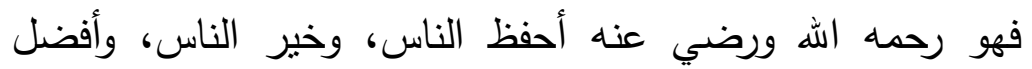

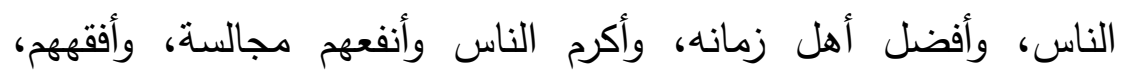
وأورعهم، وهو أعلم أهل زمانه، وأكثرهم صلاة، وأحسن الناس صله، صلاة، وأعبد الناس، وأعقل الناس، وأعظم الناس أمانة، وهو (شاهنشاة) ملك وهن وهن الملوك في الحديث

وإليك بيان بعض ما قاله العلماء في ذللك

قال خلف بن أيوب: صلار العلم من الله تعالى إلى محمد صلى الله دله دله

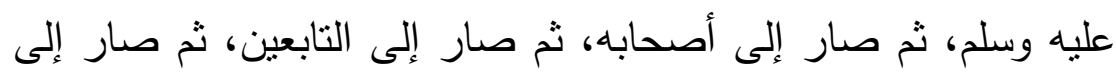

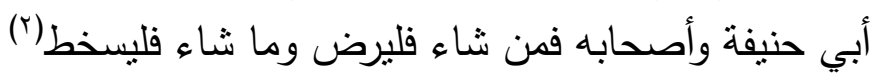

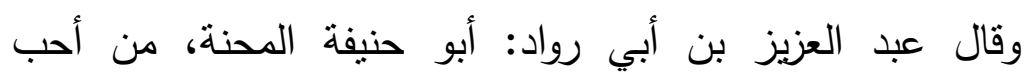

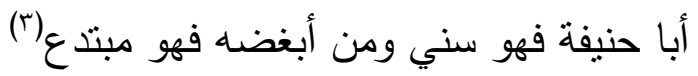

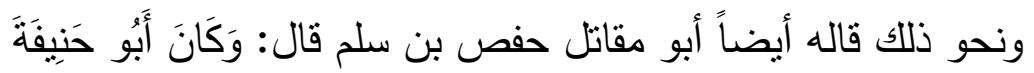

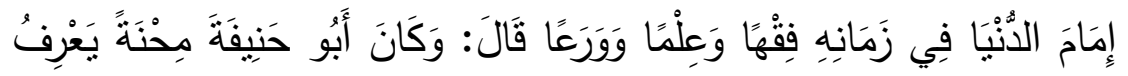

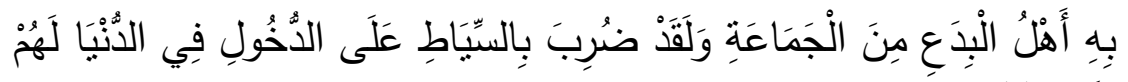
فَأَبَى ( وعن إبراهيم بن أبي معاوية الضرير (عن أبيه) من تمام السنة حب

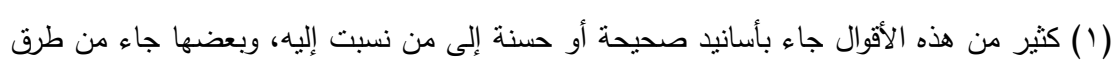
متعددة عن الثخص الواحد

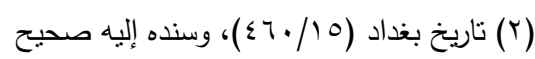

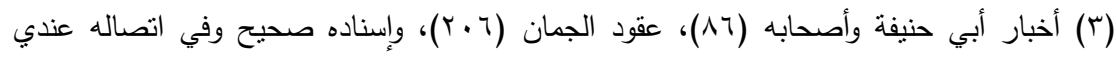

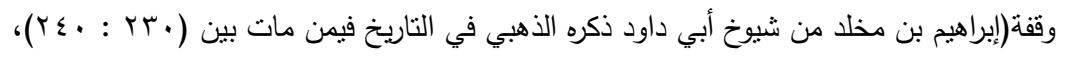

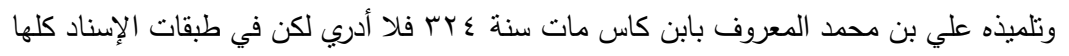
التحديث أو الإخبار

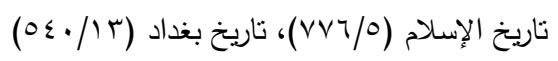

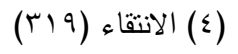




\section{نظرة منيفة إلى المكانة الحديثية للإمام الأعظم أبي حنيفة}

أبي حنيفة (1)

وقـال داود الطـائي: ذاك نجم بهتـدي بـهـ السـاري، وعلم تقبلـه قلـوب

المؤمنين.... (r)

وقال عيسى بـن موسىى للمنصـور عن أبسي حنيفة: هذا عـالم الدنيا

اليوم) (r) (- n)

وقال سفيان بن عيينة: ما مقلت عيني مثل أبي حنيفة(؟)

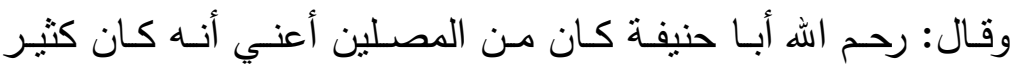

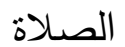

وقال أيضاً: ما قدم مكة رجل في وقتتا أكثر صلاة من أبي حنيفة

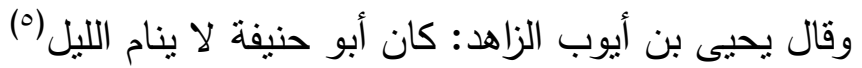

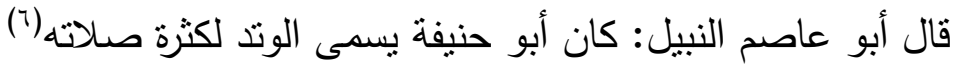

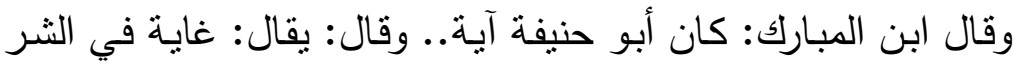

وآية في الخير (v)

وقال أيضاً: أما أفقه الناس فأبو حنيفة ما رأيت في الفقه مثنه (^)

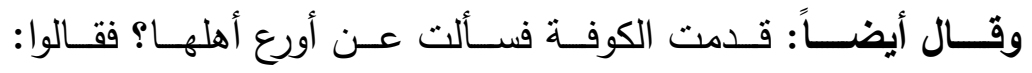

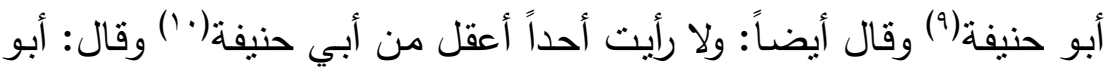

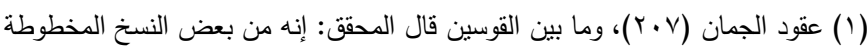

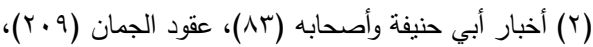

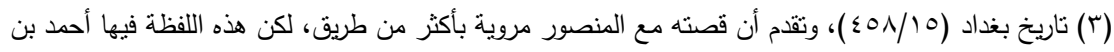

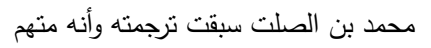

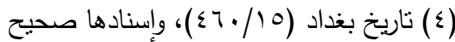

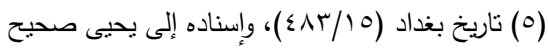

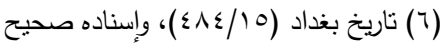

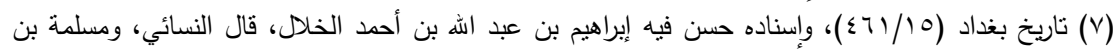

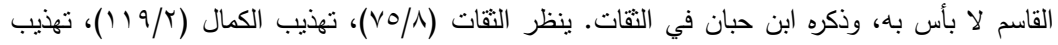

$$
\begin{aligned}
& \text { التهذيب (110/1) } \\
& \text { (1) تاريخ بغداد (10/10) (19/10) وإسناده صحيح }
\end{aligned}
$$

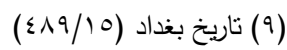

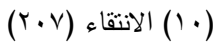




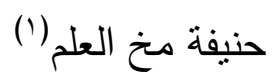

وقال أبو يحيى الحماني: ما رأيت رجلاً قط خيراً من أبي حنيفة

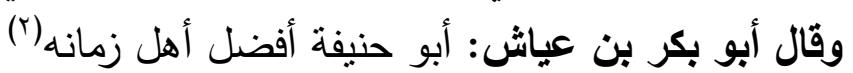

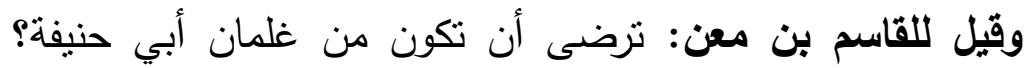

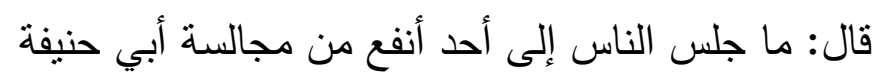
ولما جلس حجر بن عبد الجبار إلى أبي حنيفة قال: ما رأيت منل إنل

هذ|(r)

وقال القاسم بن معن أيضاً: ما رأيت أحسن أمانة من أبي حنيفة(؟)

حنيفة(£)

وقال حجر بن عبد الجبار: ما رأى الناس أكرم مجالسة من

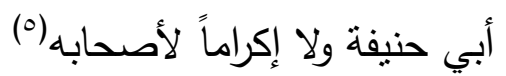

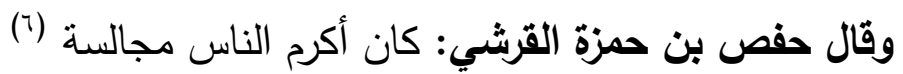

قال أبو جعفر الرازي: ما رأيت أحداً أفقه من أبي حنيفة، ومان أكمان رأيت

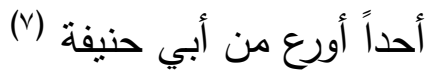

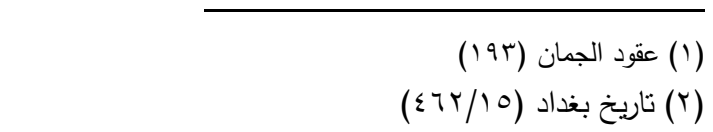

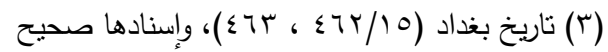

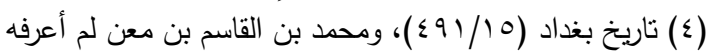

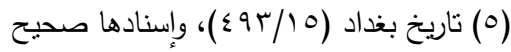

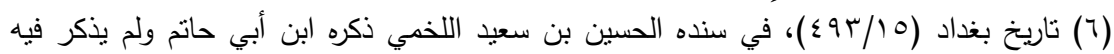

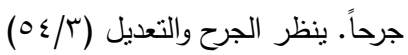

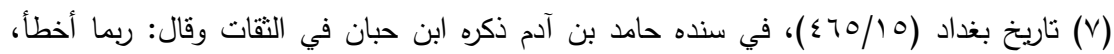

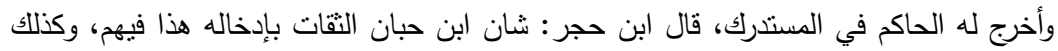

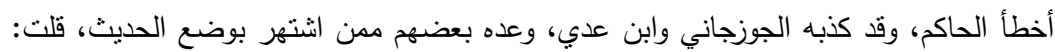

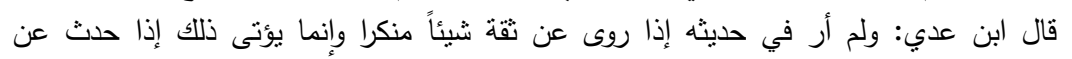

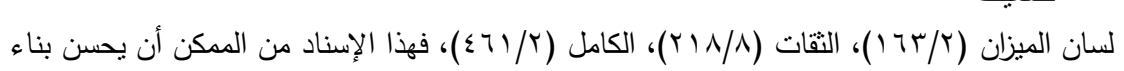

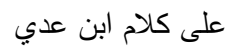




\section{نظرة منيفة إلى المكانة الحديثية لإمام الأعظم أبي حنيفة}

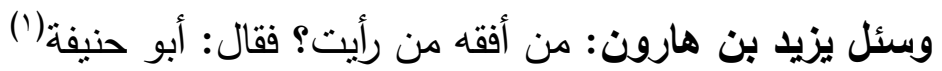

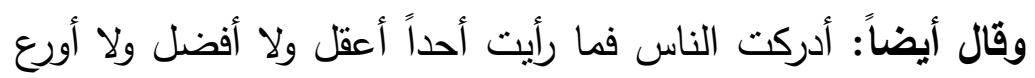

من أبي حنيفة( موال

وسوف يأتي (إن شاء اله) عن يزيد بن هارون أيضاً أن أبا حنيفة

أحفظ أهل زمانه

وقال سفيان الثوري عن أبي حنيفة: أفقه أهل الأرض(r)

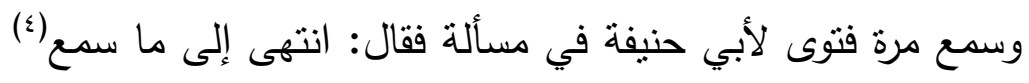

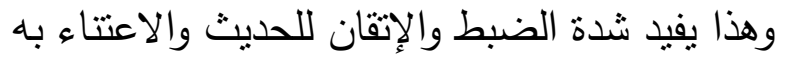

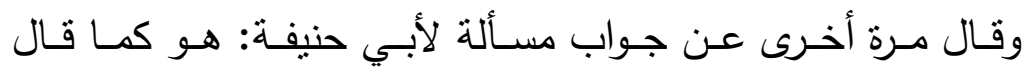

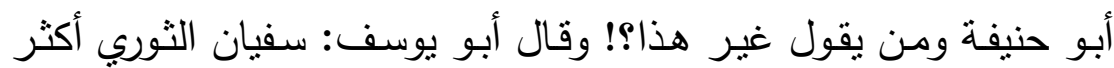

منابعة لأبي حنيفة مني (0)

قال أبو بكر بن عياش: في قصة أنينة أنيا نعزي سفيان (الثوري في

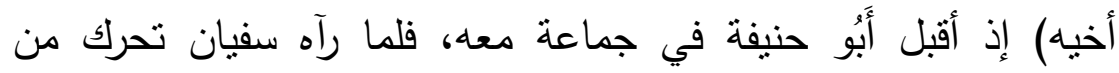

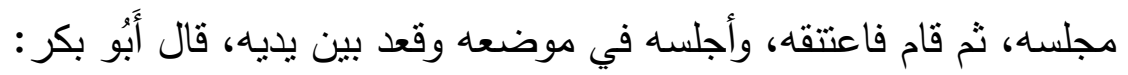

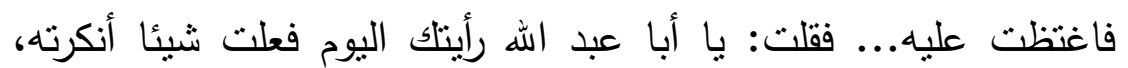
وأنكره أصحابنا عليك... فقال: وما أنكرت من ذاك! هذا رجل من العلم

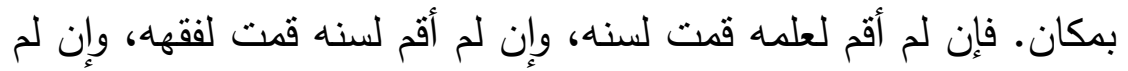

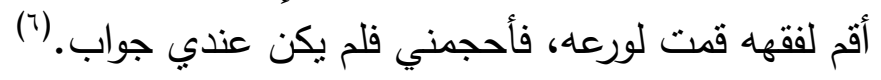

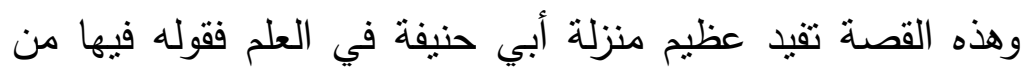

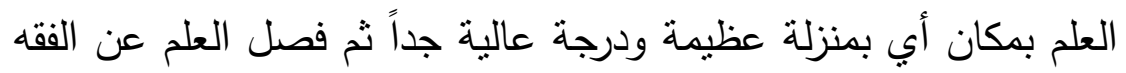

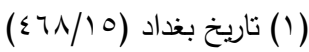

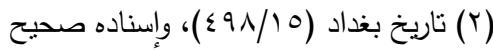

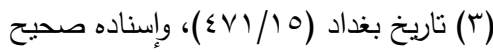

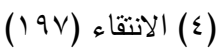

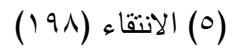

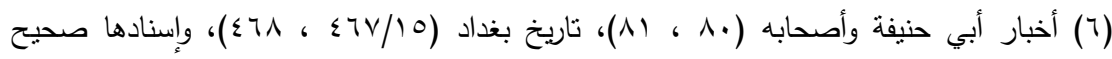

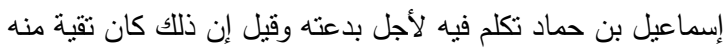


فهو بمنزلة عالية في العلم عموماً ومنه الحديث وله اختصاص بالفقه إن إن إنها لم أقم لعلمة قمت .. لفقهه وقـال عبـد الله بـن يزيـــ المقـري: مـا رأيـت أسـود رأس أفقـهـهـ مـن

أبي حنيفة(1)

وقال شداد بن حكيم: ما رأيت أعلم من أبي حنيفة (r)

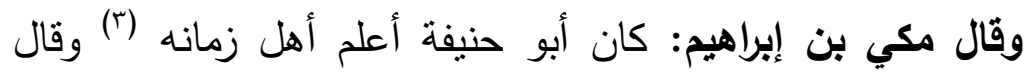

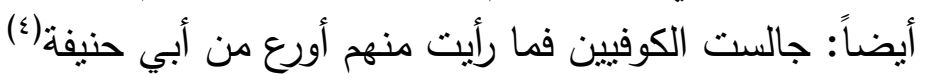

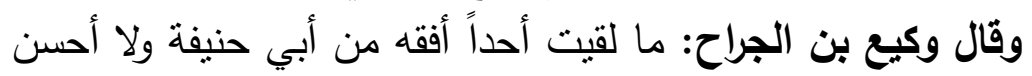

صلاة منه (0)

وقال ابن شبرمة: عجزت النساء أن تلا مثل النعمان (؟) آنان

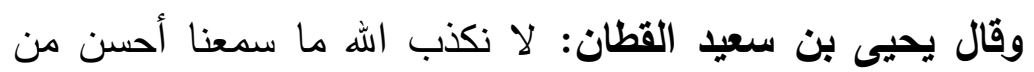
رأي أبي حنيفة، وقد أخذنا بأكثر أقواله

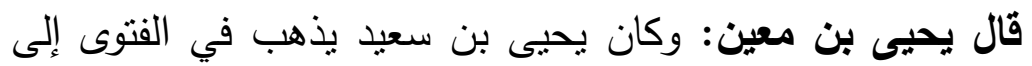

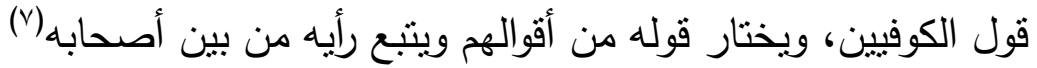

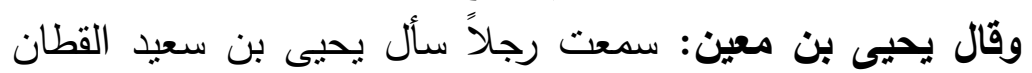

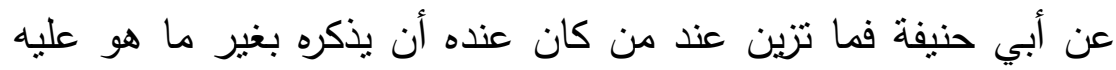
قال: والله إنا إذا استحسنا من قوله الشيء أخذناه. وفي رواية: ما نتزين

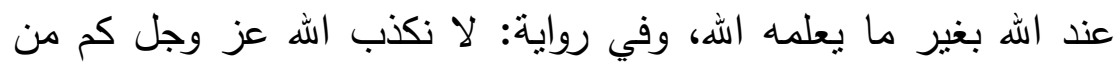
شيء حسن قاله أبو حنيفة، وفي رواية: أرأيتم إن عبنا على أبي حنيفة

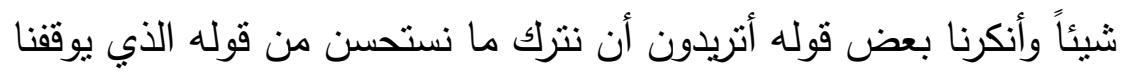

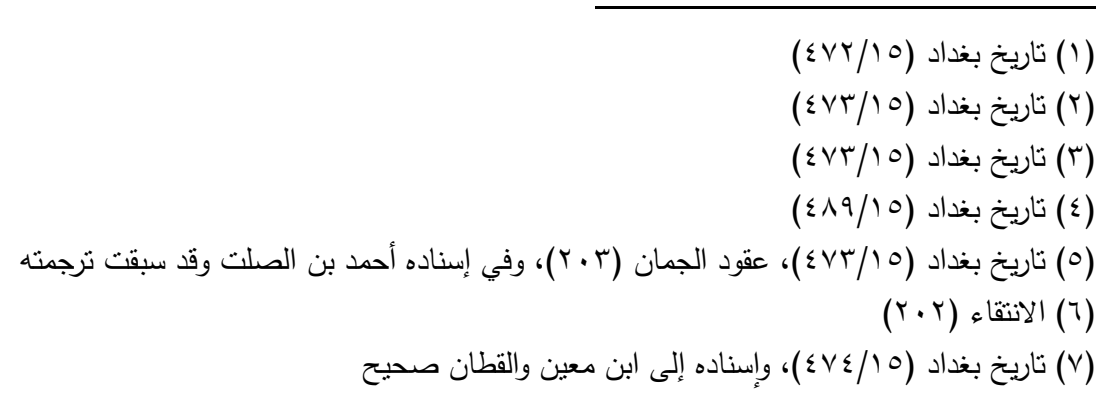


عليه (')

قال العلامـة عبد الفتـاح أبـو غدة: مـا تزين أي مـا جامل السـئل

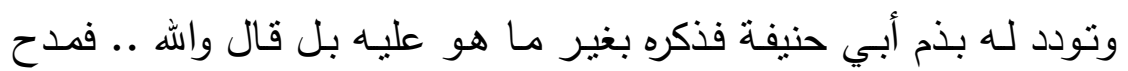

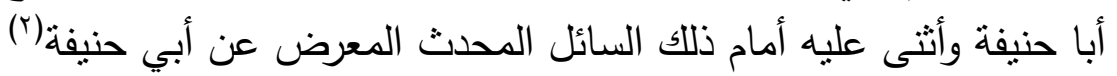
أقول: إنما ذكرت كلام الإمام يحيى بن سعيد القطان هنا لقوله القانه ما سمعنا أحسن من قوله، ولقوله: كم من شيء حسن قاله أبو حنيفة، وهذه القصة أيضاً تقيد مع ما قاله فضيلة العلامة الدكتور عبد الفتاح

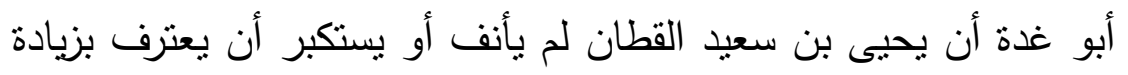

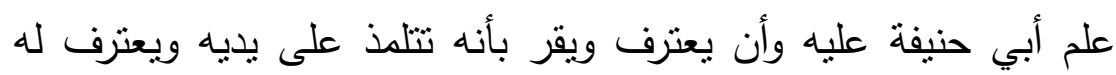
بمزيد العلم والتقدم ولذا يتبع أكثر أقواله ويجعلها أحسن ما سمع في بانه المسألة

ومن الدليل على ذلك ما جاء عنه أنه قال: جالسنا واله أبا حنيفة وسمعنا منـه، وكنت والله إذا نظرت إليـه عرفت في وجهـه أنسه يتقي الله

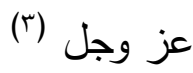

وقال الإمام الثافعي: ما رأيت أفقه من أبي حنيفة، قال الخطيب:

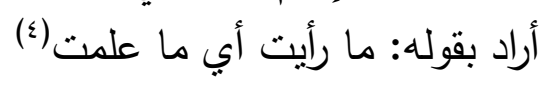
وقال الإمام الشافعي أيضاً: الناس عبال عال على أبي حنيفة في

الفقه (0) وقال إبراهيم بن عكرمة المخزومي: ما رأيت أحداً أورع ولا أفقه من

أبي حنيفة (T)

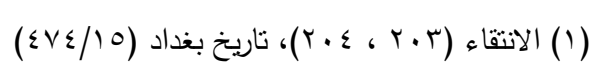

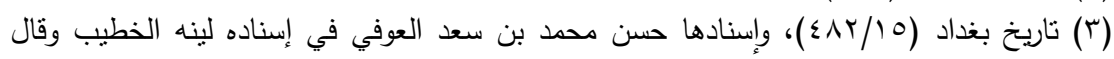

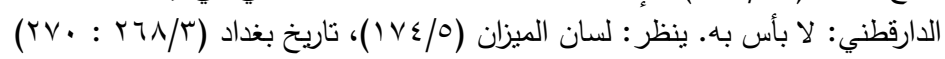

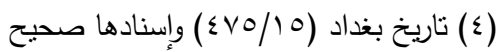

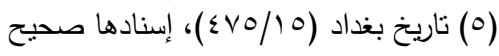

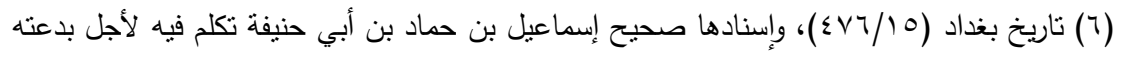


وقال الحكم بن هشام الثقي: .. وكان (أبو حنيفة) من أعظم

الناس أمانة (1)

وقال الحسن بن محمد الليثي: قدمت الكوفة فسألت عن أعبد أهلها

فدفعت إلى أبي حنيفة ثم قدمتها وأنا شيخ فسألت عن أفقه أهلها فدفعت

إلى أبي حنيفة (؟)

وقال عيسى بن يونس: إني والله ما رأيت أفضل منه، ولا أورع

منه، ولا أفقه منه (r)

وقال سعيد بن أبي عروية: كان أبو حنيفة عالم العراق(؛) ولها

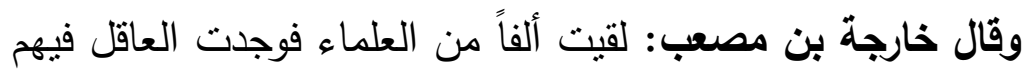

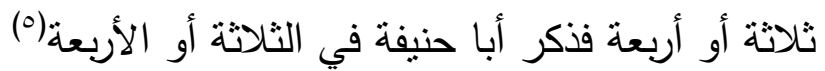
وقال أبو جعفر محمد بن علي الباقر: ما أحسن هديه وسمتهنه، وما

أكثر فقهه (7)

وقال حماد بن زيد: أردت الحج فأتيت أيوب أودعه، فقال: بلغني

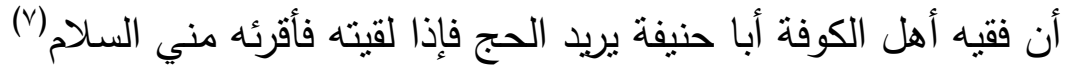
فهذه نقول عن أكثر من ثناثين عالم من أجلة العلماء يصفون الإمام بأنه الأفضل إما مطلقاً أو مقيداً بوصف أو أو زمن أو مكان

بد عته وقيل إن ذلك كان تقية منه

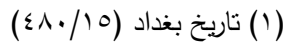

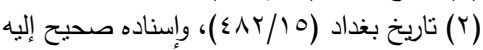

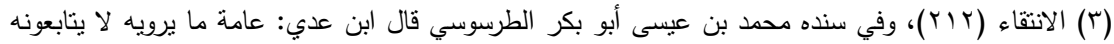

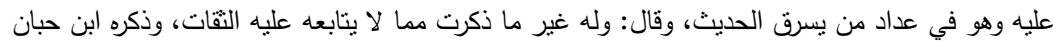

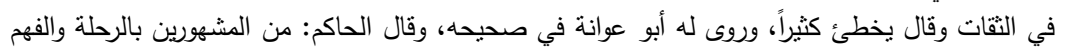

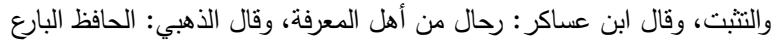

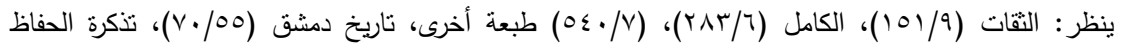

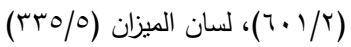

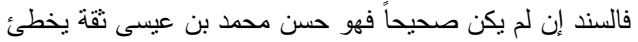

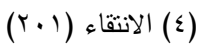

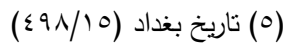

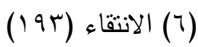

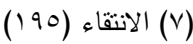




\section{نظرة منيفة إلى المكانة الحليثية للإمام الأعظم أبي حنيفة}

والتفضيل المطلق أو التفضيل بالعلم والفقه هو أعلى درجات التوثيق فالحديث جزء من الخير الذي فضل به الفيه كما أن من قال أعلم الناس ونحوها فإن الحديث داخل في هذه

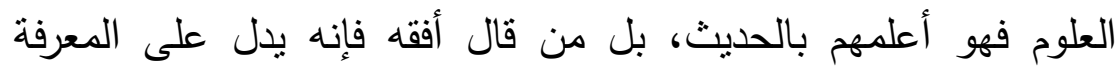
بالحديث فإنه لا يستقيم الفقه والاجتهاد فيه إلا بالحديث، قال بال الصالحي

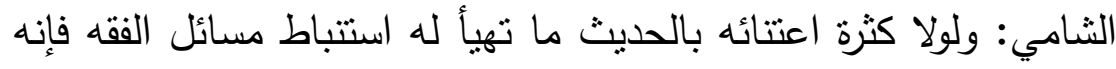

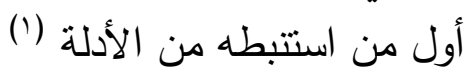
ولذا كان الإمام أبو حنيفة ملك الملوك في علم الحديث الثريف

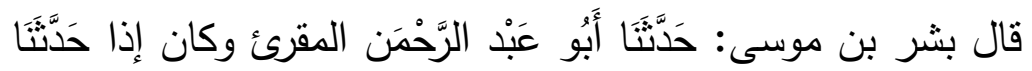

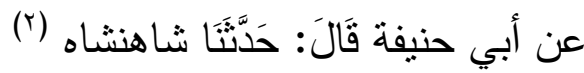
وقال محمد بن الحسن: كان أبو حنيفة واحد زمانه ولو انشقت عنه أنهان

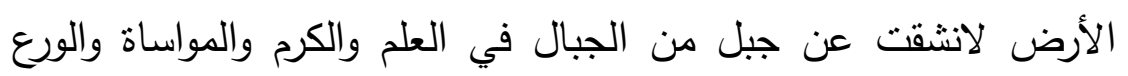

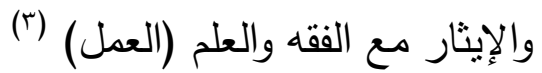

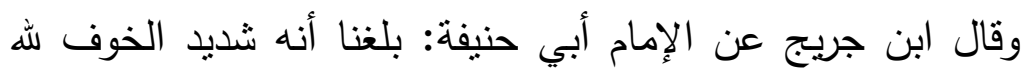

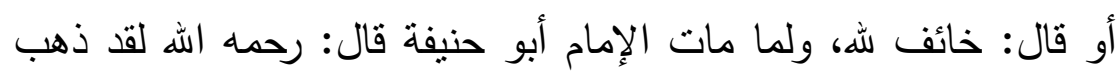

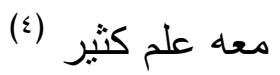
وقال الإمام شعبة لما مات أبو حنيفة: لقد ذهب معه فقه الكوفة، تفضل اله علينا وعليه برحمته(o) وقال أيضاً: لقد طفئ عن أهل الكوفة

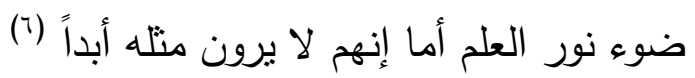

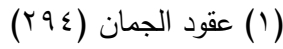

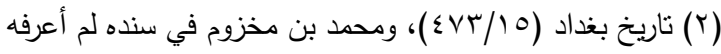

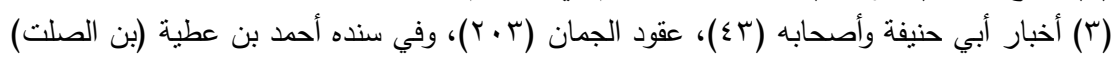

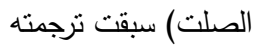

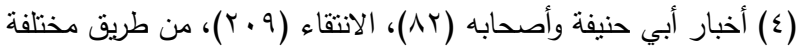

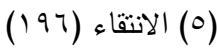

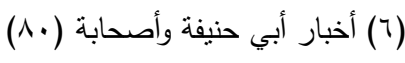




\section{نظرة منيفة إلى المكانة الحديثية لإمام الأعظم أبي حنيفة}

\section{البحث الثاني}

ما جاء من التعديل وبيان عظيم منزلته في علم الحديث غير ما تقدم من ذلك مـا جـاء في كلام العلمـاء في أصـح الأسـانيد وأن الإمـام رحمه الله داخل في ذلك

فقد قيل في إن أصـح الأسـانيد مالك عن نـافع عن ابن عمر وهو

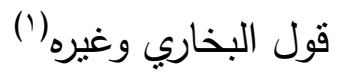

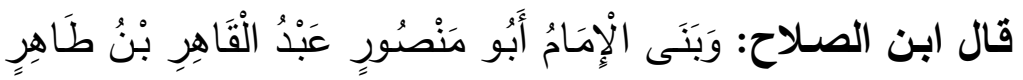

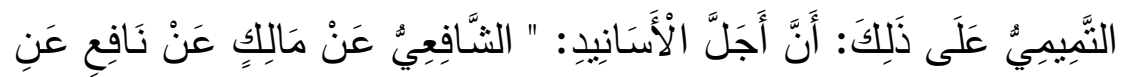

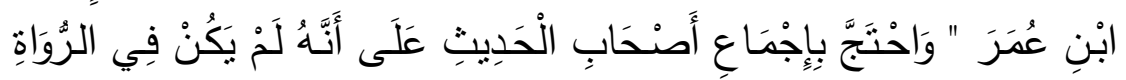

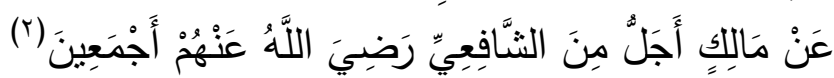

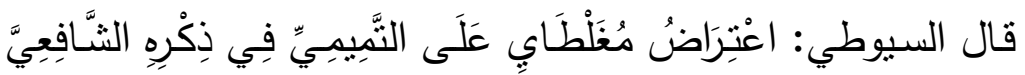

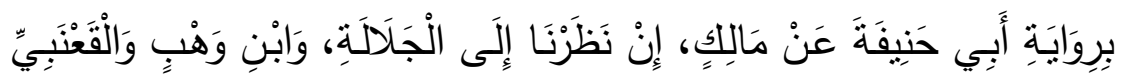

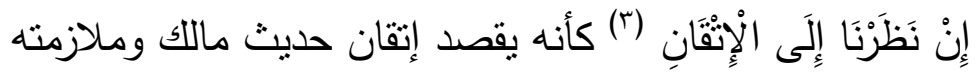

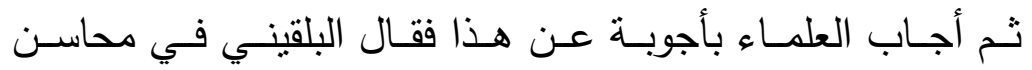
الاصطلاح: رواية أبي حنيفة عن ماللك لم تشتهر كاثتهار رواية الثافعي وقال العراقي: روايتهه عن ماللك ليست مـن روايته عن ابن عمر والمسألة مفروضة في ذلك

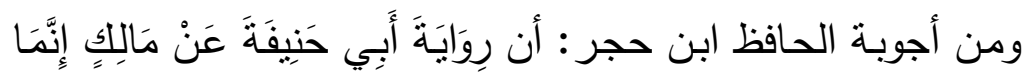

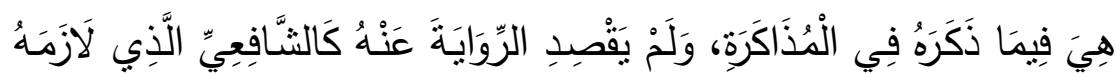

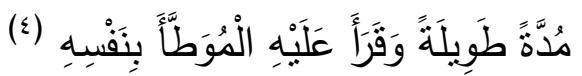


والخلاصة أن هؤلاء جميعاً (الحافظ مغلطاب، والبلقيني، والعراقي،

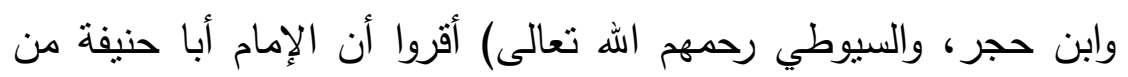
شرط أصح الأسانيد فهو فوق الثقة وإنما لم يذكر في ترجمة أصح

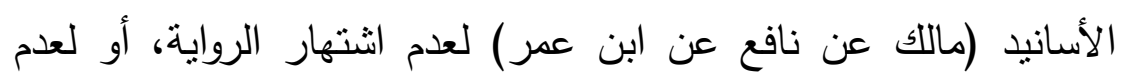
ثبوتها (ثبوت روايته عن ماللك من حديث نافع) أو لكونه ذكرها على سبيل المذاكرة ولم يذكرها على سبيل التحديث

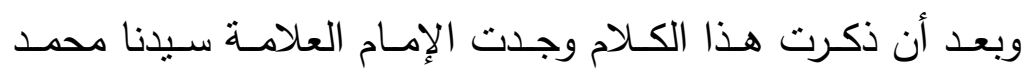

عبد الرشيد النعماني ذكره ثم عقب عليه بقوله: فانظر يا رعاك الهه هؤلاء

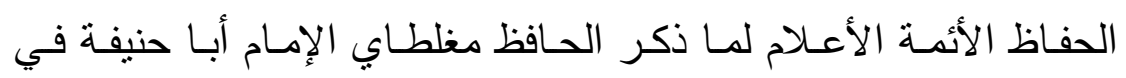

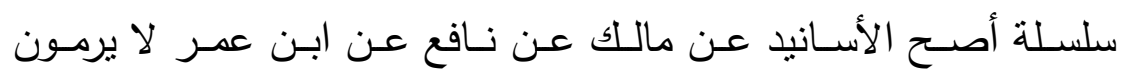

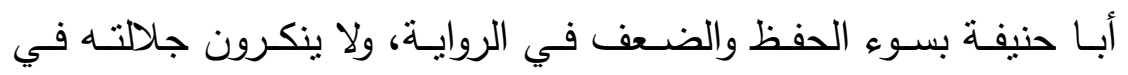
الحديث ولا إتقانه في الرواية، إنما ينكرون على مغلطاي إخخاله في هذه

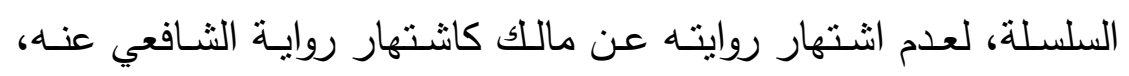
أو لأنها وقعت في المذاكرة ولم يقصد أبو حنيفة الرواية عنه... ثم قال:

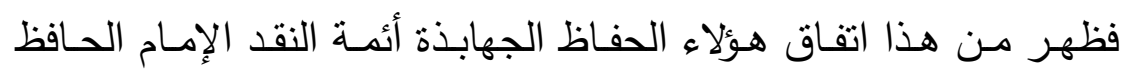
مغلطاي والإمام الحافظ البلقيني، والحافظ العراقي، وشيخ الإسـام الحافظ

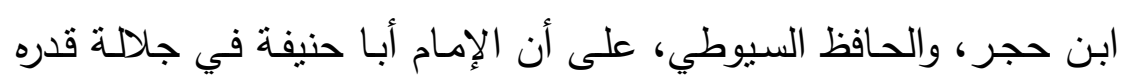
وإتقانه في الحديث قرين ماللك والثافعي رحم الله الجميع

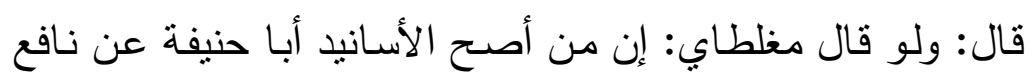

$$
\text { عن ابن عمر لكان لله وجه }
$$

قـال: ولا ريب أن مـن أصـح الأسـانيد أبـا حنيفـة عـن عطساء بـن أبي رباح عن ابن عباس وهذا الإسناد ذكره الإمام عبد الوهاب الثعراني 


\section{نظرة منيفة إلى المكانة الحديثية للإمام الأعظم أبي حنيفة}

في ميزانه الكبرى(')

ثم ناقش رحمه الله في صفحات نالية لذلك أوجهاً أخرى للخول الإمام أبي في أصح الأسانيد وكون حديثه في أعلى درجات الصحيح من ذلك قول وكيع: حديث يتداوله الفقهاء خير من حديث يتداوله الثنيوخ، وترجيح الحديث المسلسل بالأئمة على أحاديث الصحيحين في بعض الصغ

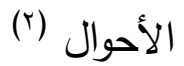

أقول ومما يمكن أن يضاف إلى ذلك في مسألة أصح الأسانيد أنهم

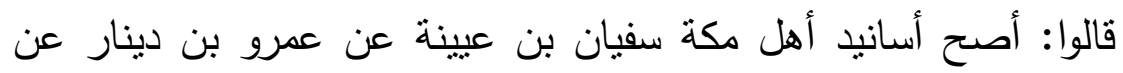

جابر (r)

والذي مكن لهذا الإسناد أبو حنيفة لمعرفته به ولمكانته في الحديث قال سفيان بن عيينة: أول من أقعدني للحديث بالكوفة أبو حنيفة،

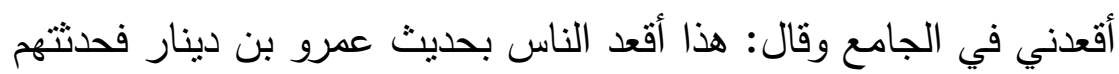
وفي رواية الصيمري: فاجتمع إلي المشايخ يسألوني عن حديث عمرو بن بنائ دينار (ई) ورأ)

فالذي أقعد سفيان بن عيينة رحمه اله للحديث، وأرشد الناس إليه

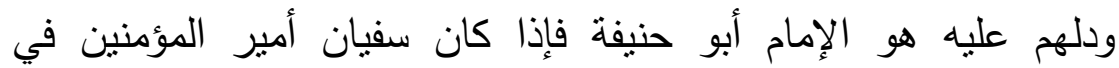

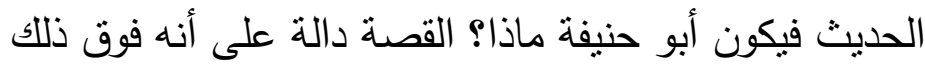

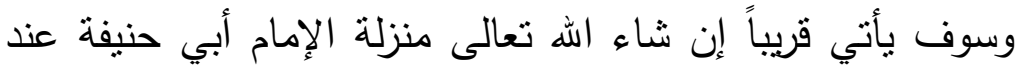
عمرو بن دينار وعند عطاء بن أبي رباح

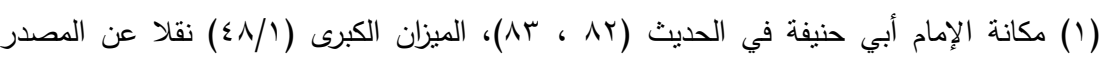
الذذكور

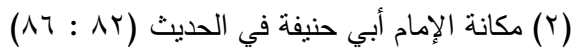

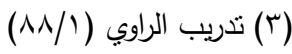

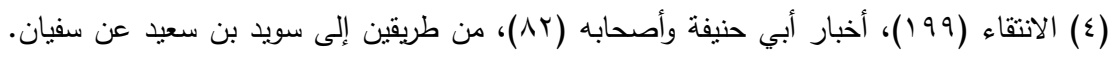


وقال أبو داود: رحم الله مالكاً كان إماماً، رحم الله الثافعي كان

إماماً، رحم اله أبا حنيفة كان إماماً) (1)

وقال الإمام التزمذي في كتاب العلل في كلام طويل في مشروعية

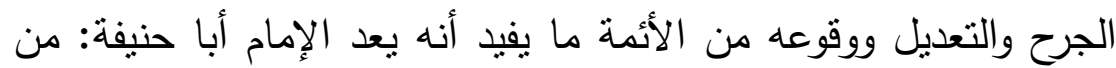
العلماء الأئمة الذين بينوا أحوال بعض الرواة شفقة على الدين ونتبناً حيث

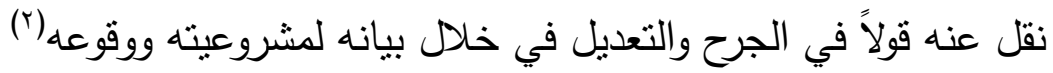

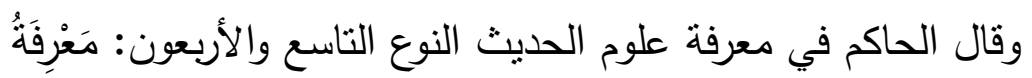

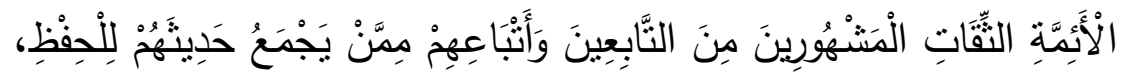

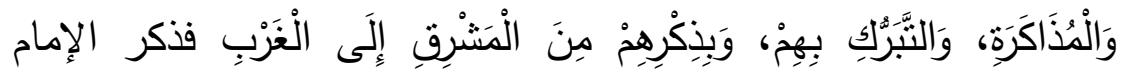

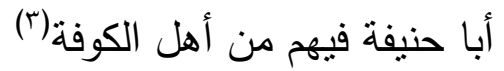
وقال في المستدرك عند ذكر بعض الأحاديث: هَكَذَا رَوَاهُ عَبُْ

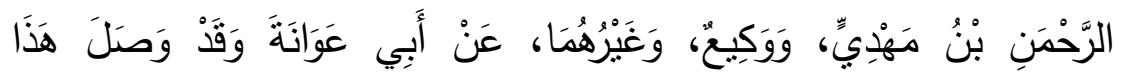

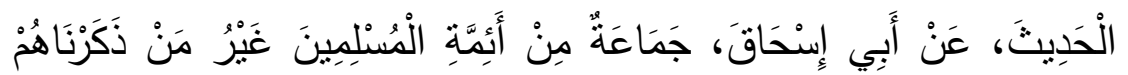

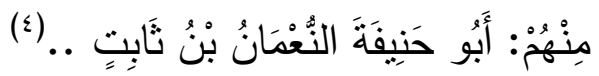
وقال البيهقي في مدخل دلائل النبوة: جعل الله في الأمة في كل عصر من الأعصار أئمة يقومون بييان (الثريعة) وحفظها على (الأمة)

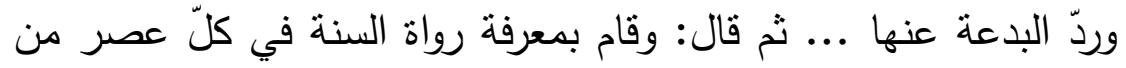
الأعصار جماعة وققوا على أحوالهم في التعديل والجرح وبيّنوها ودوّنوها في الكتب حتى من أراد الوقوف على معرفتها وجد السبيل إليها. وقد تكلّم فقهاء الأمصار في الجرح والتعديل فمن سواهم من علماء الْحَدِيثَ فذكر الْهر 


\section{نظرة منيفة إلى المكانة الحديثية للإمام الأعظم أبي حنيفة}

في أول من نقل عنه في ذلك الإمام أبا حنيفة (')

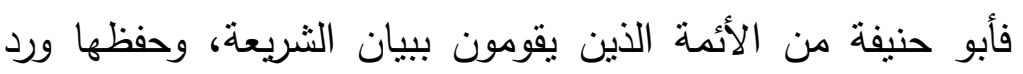

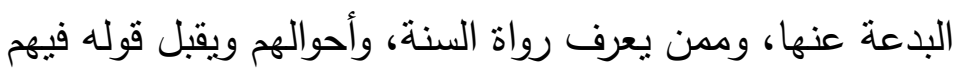

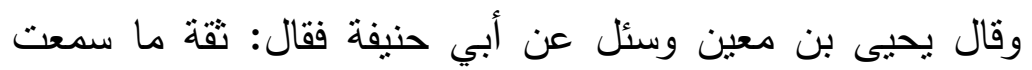

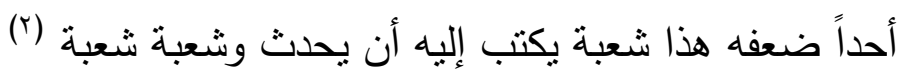
وهذا دليل أنه لم يوجد إلى زمن ابن معين من يضعف إله الإمام بشيء وإذا كان شعبة أمره أن يحدث فإنه قال عنه: كان واله إنه حسن الفهن

جيد الحفظ حتى شنعوا عليه بما هو أعلم به منهم (r)

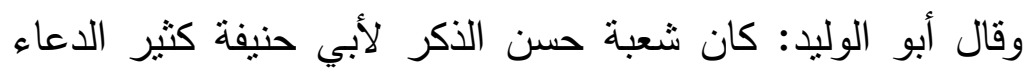

له، ما سمعته قط يذكر بين يديه إلا دعا له (؟) أله

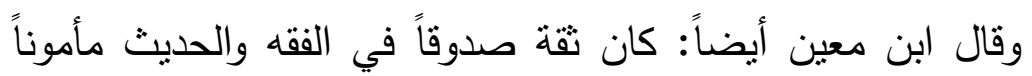

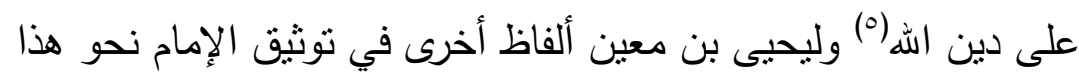

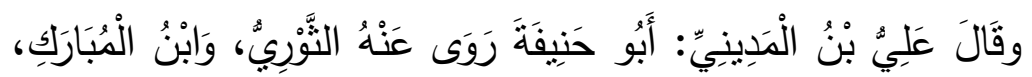

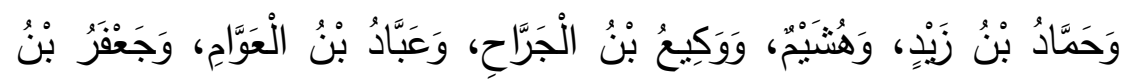

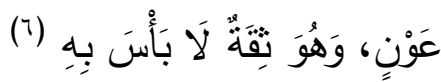

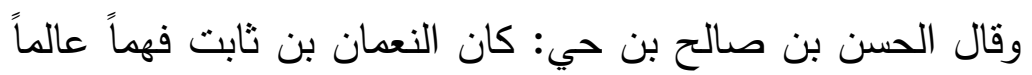

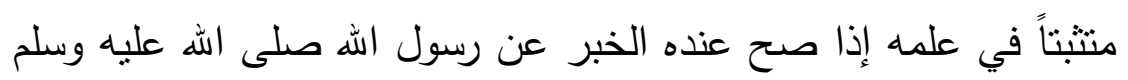

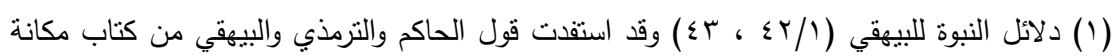
أبي حنيفة في الحديث النيث للايث

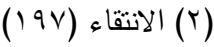

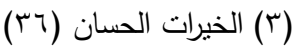
(§) أخبار أبي حنيفة وأصحابه (•^)، وكون شعبة حسن الرأي في أبي حنيفة مروي بأسانيد صحيحة

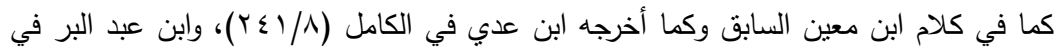

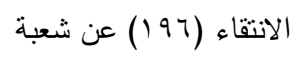

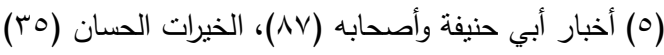

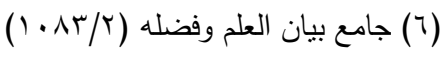


لم بعده إلى غيره (1) وقال يزبد بن هارون: كان أبو حنيفة ثقباً نقباً زاهداً عالماً صدوق اللسان، أحفظ أهل زمانه سمعت كل من أدركته من أهل زمانه يقول إنه ما رأى أفقه منه (r) وذكر الإمام ابن جرير الطبري أبا حنيفة وأطراه وقال: كان فقيهاً عالماً ورعاً (r)

والإمام رحمة الله له ذكر في ثقات ابن شاهين، (ء) والعجلي، (0) وذكره الحافظ الذهبي في تذكرة الحفاظ وتبعه السيوطي في طبقات الحفاظ ووصفه الذهبي بالإمام الأعظل فهو عنده من معدلي حملة العلم النبوي وممن يرجع إلى اجتهادهم في التوثيق والتضعيف والتصحيح والتزبيف كما قال في مقدمة هذا الكتاب(اب)

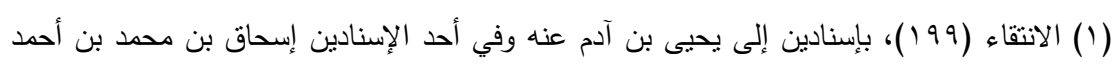

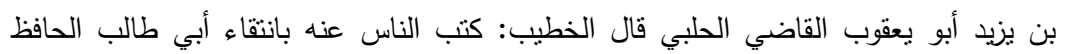

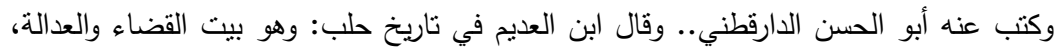

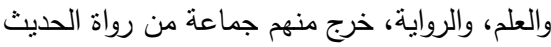

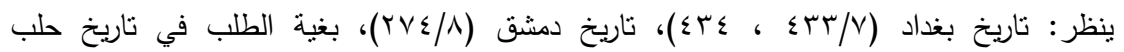
(10.r/ ) وفي الإسناد الآخر من لم أعرفه فالإسناد على هذا حسن على الأقل

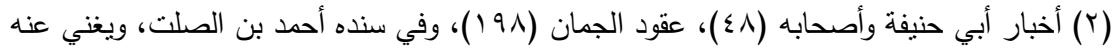
ما سبق عن بزيد بن هارون بأسانيد صحيحة

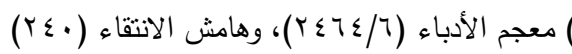

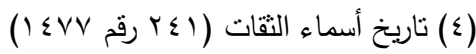

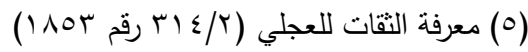

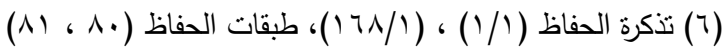




\section{البحث الثالث \\ ما جاء تعديلاً للإمام ودفاعاً عن الإمام إجمالاً}

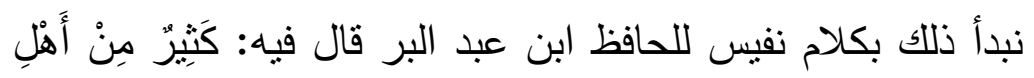

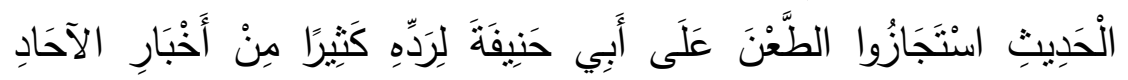

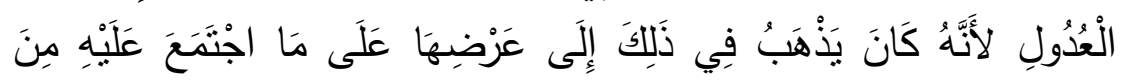

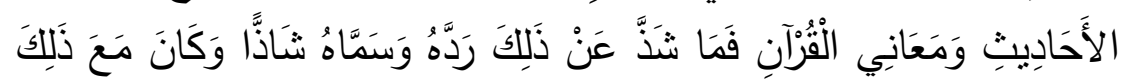

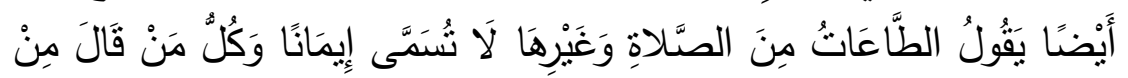

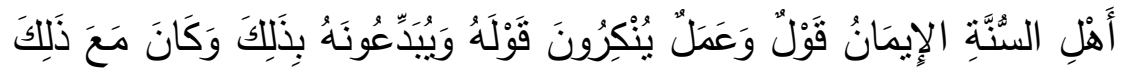

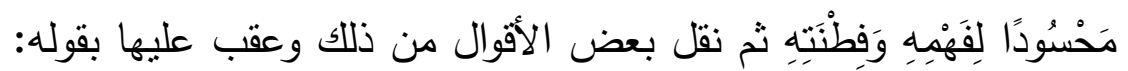

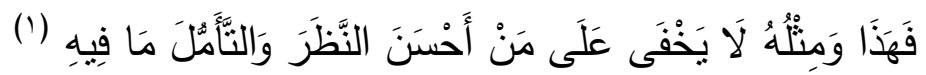

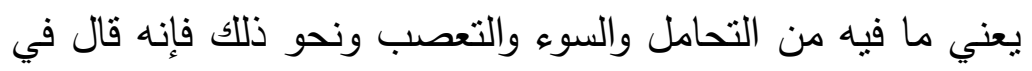

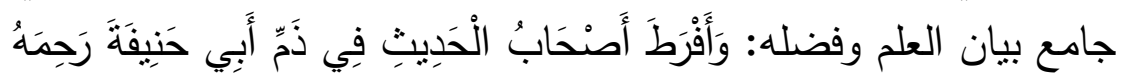

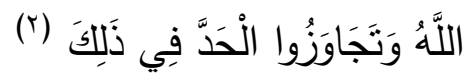

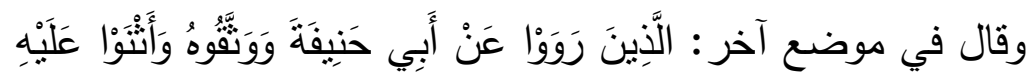

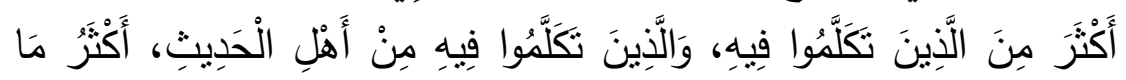

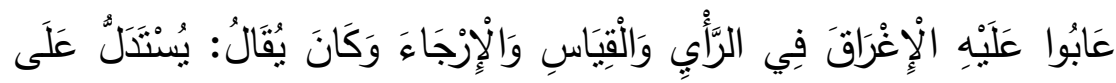

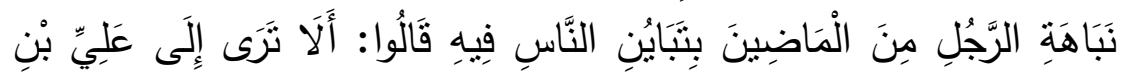

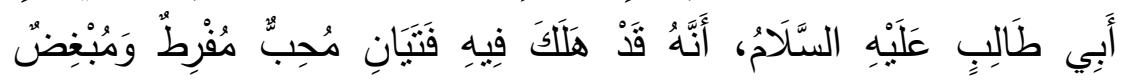

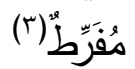

وقال بعد ذللك: وَالصَّحِيحُ فِي هَذَا الْبَابٍ أَنَّ مَنَ صَحََّنْ عَدَالَتُهُ

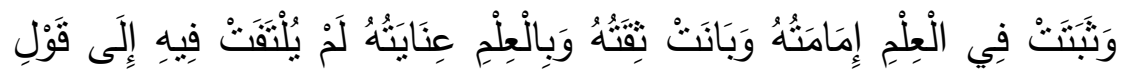

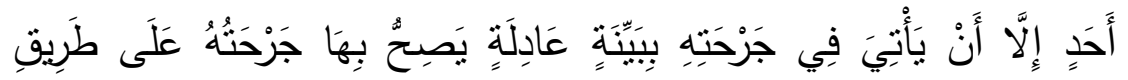

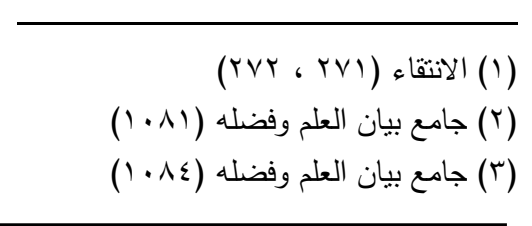




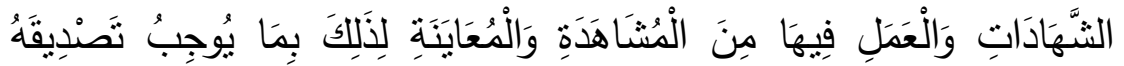

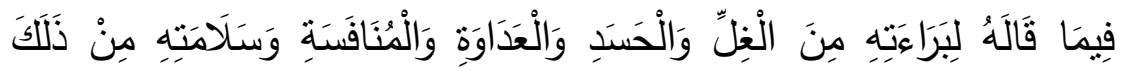

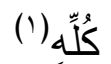

وقد جاءت أثنياء كثيرة تعتبر تعديلاً للإمام أبي حنيفة ودفاعاً عنه فئه

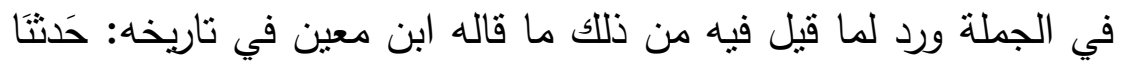

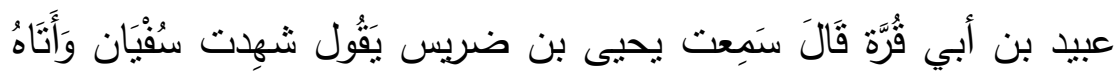

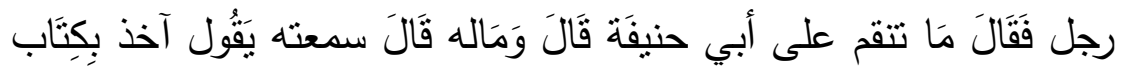

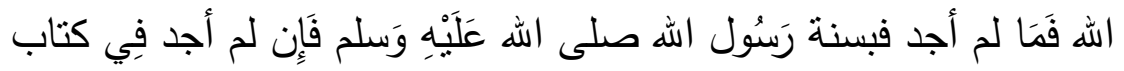

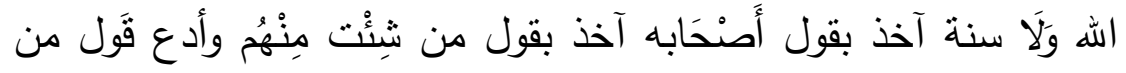

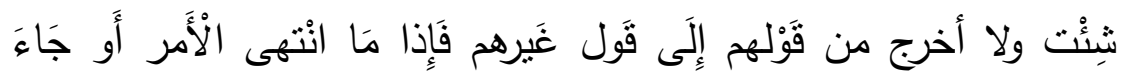

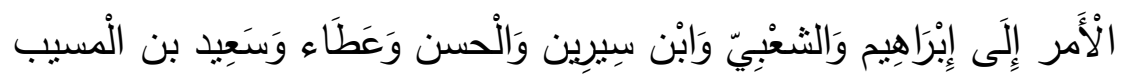

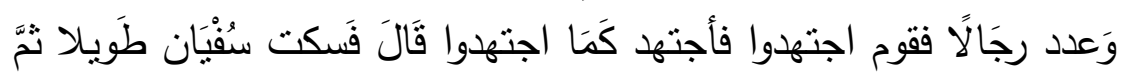

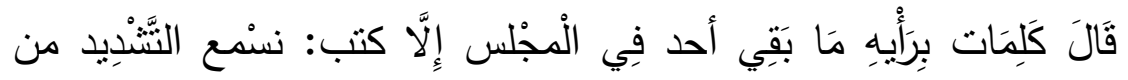

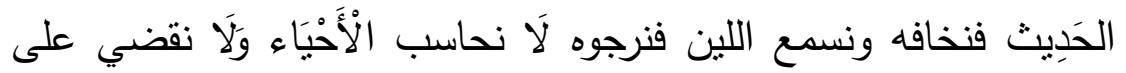

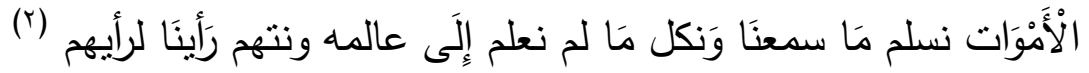

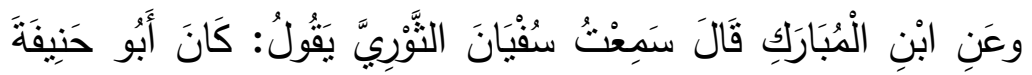

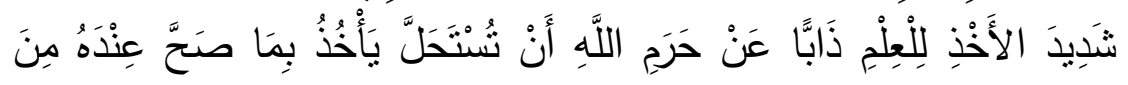

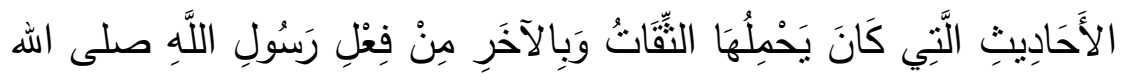

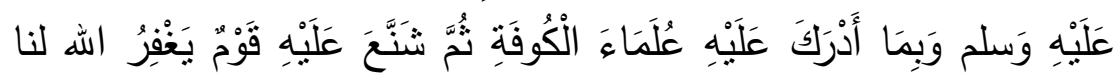

وفي روايـة أنه بعد أن نـاقش ابن المبارك في مسألة فقهية برأي أبي حنيفة قال لـه: إن كان أبو حنيفة ليركب من العلم أحد من سنان العبان

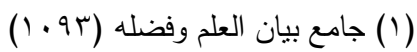

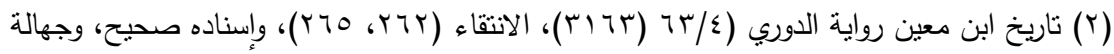

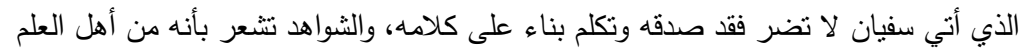

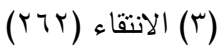




\section{نظرة منيفة إلى المكانة الحديثية للإمام الأعظم أبي حنيفة}

الرمح كان والله شديد الأخذ للعلم .. إلى أن قال: قد شنع عليه قوم فسكتنا عنهم بما نستغفر الله تعالى منه (1) فهنا الإمام سفيان الثوري، يؤكد التعديل وشدة التوثيق لأبي حنيفة، وكأنه نُقِل عنه شيء أو أشيع شيء على سبيل الخطأ فجاءه هذا الرجل فأنكر منل ذلك أو نراجع عنه نهيه وقال مسعر بن كدام: حسد أهل السير النعمان بن ثابت لفه لفهم

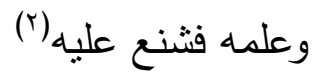

وسئل عبد السلام بن حرب الملائي: هل استتيب أبو حنيفة؟ فقال:

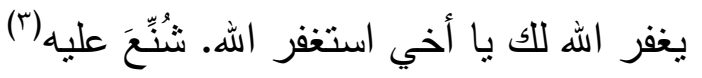

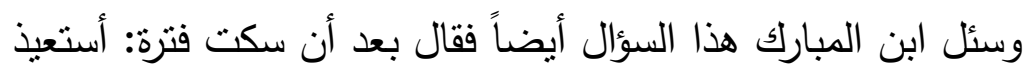

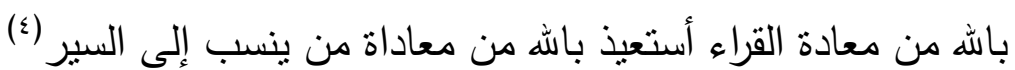

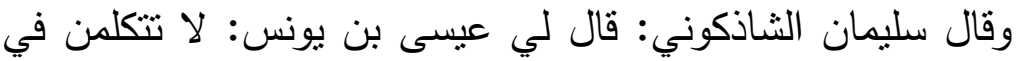
أبي حنيفة بسوء، ولا تصدقن أحداً يسيء القول فيه فإني والله ما رأيت

$$
\text { أفضل منه ولا أروع منه ولا أفقه منه (ن) }
$$

وقيل للفضل بن موسى السيناني: ما تقول في هؤلاء الذين يقعون في أبي حنيفة؟ قال: إن أبا حنيفة جاءهم بما يعقلون وبما لا يعقلون من هن لهن

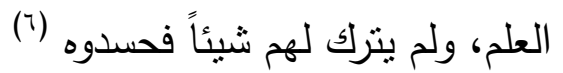
وقيل للنضر بن محمد: كان أبو حنيفة يرى السيف؟ قال: معاذ

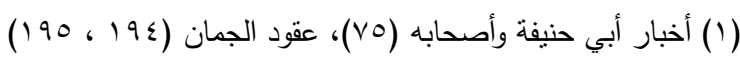

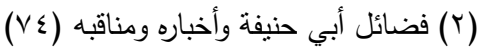

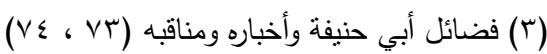

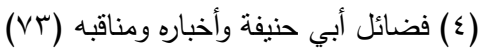

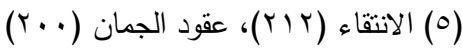

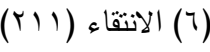
(V0) فضائل أبي حنيفة وأخباره ومناقبه (V) 
وقال أبو بكر المروزي: سمعت أبا عبد الله أحمد بن حنبل يقول: لم

يصح عندنا أن الإمام أبا حنيفة قال: القرآن مخلوق، فقلت: الحمد لله يا

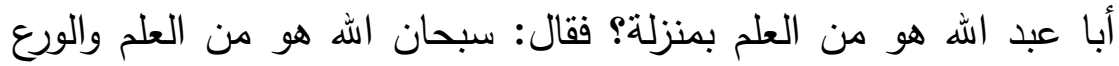
والزهد، وإيثار الدار الآخرة بمحل لا يدركه فيه أحد، ولقد ضرب بان بالسياط على أن يلي القضاء لأبي جعفر المنصور فلم يفعل فرحمة الهه عليه ورضوانه (')

وقال المعلى بن منصور : كان محمد بن الحسن إذا أخبر أن قوماً يذكرون أبا حنيفة وأصحابه تمنل بهذا البيت:

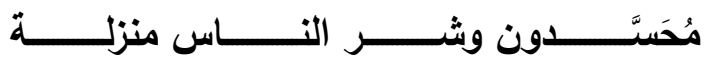

\section{من عاش في الناس يومـاً غير محسود(؟)}

وقال عبد الله بن داود الخربيي: الناس في أبي حنيفة رجلان جاهل

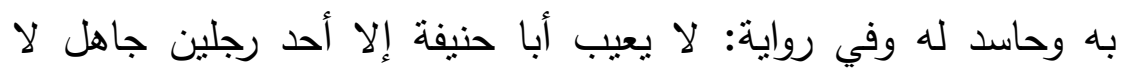
يعرف فضل قوله، أو حاسد لم يقف على علمه فحسده(")

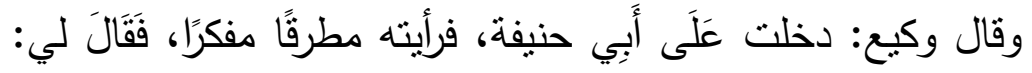

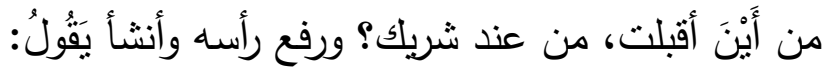

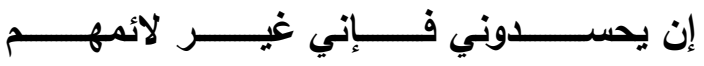

قبلي من الناس أهل الفضل قد حسوا
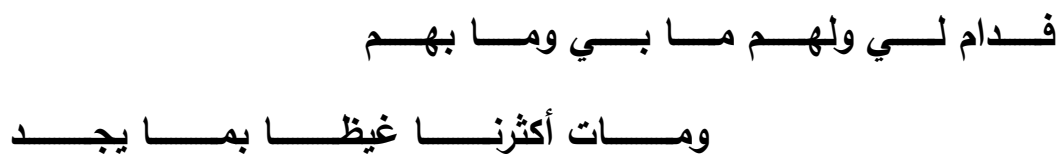

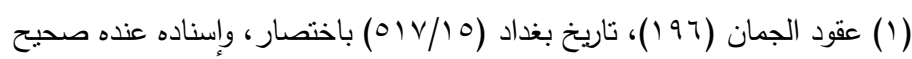

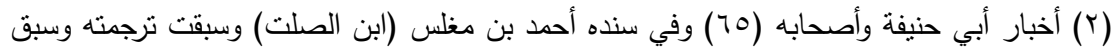




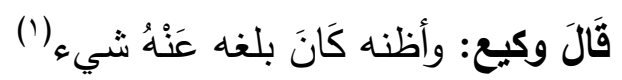
وقال عبد الحميد الحماني ويلغه وقوع الناس في أبي حنيفة: لم أله

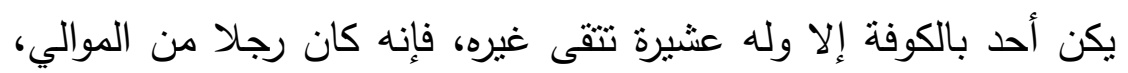

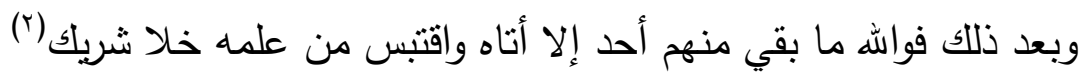
وقال أبو سليمان الجوزجاني: كان أبو حنيفة سهل اله تعالى له هذا

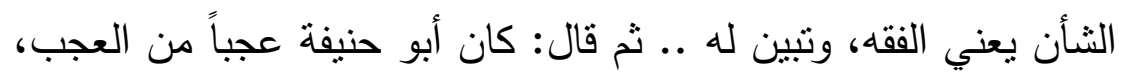

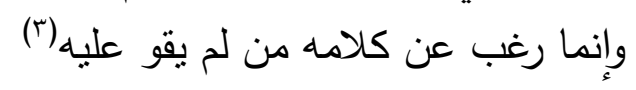

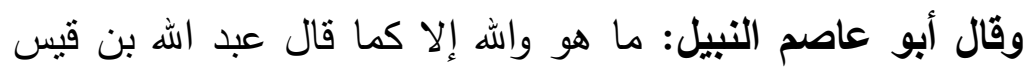
الرقيات

الله بمــا فضـلت بـهـ النجبـاءع(؛)

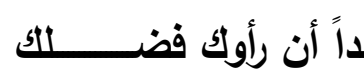

وقال أسد بن حكيم: لا يقع في أبي حنيفة إلا جاهل أو مبتدع (0) وقيل ليزيل بن هارون: ما تقول في أبي حنيفة والنظر في كتبه؟

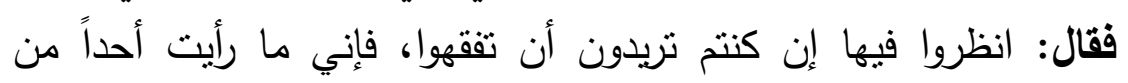

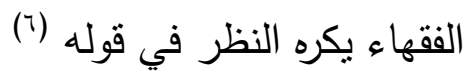
وكان ابن المبارك يوماً جالساً يحدث الناس فقال: حدثني النعمان بن ثابت فقال بعضهم: من يعني أبو عبد الرحمن؟ فقال أعني أبا حنيفة

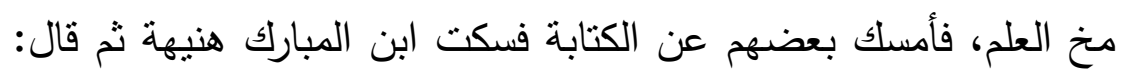
يا أيها الناس ما أسوأ أدبكم وما أجهلكم بالأئمة، وما أقل معرفتكم بالعلم وأهله، ليس أحد أحق أن يقتدى به من أبي حنيفة، لأنه كان إماماً تقياً نقياً ورعاً عالماً فقيهاً كثف العلم كثفاً لم يكثفه أحد ببصر وفهم وفطنة

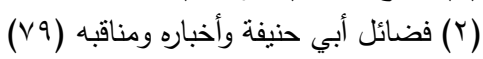
(

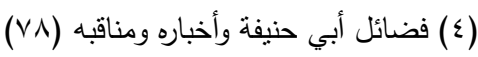

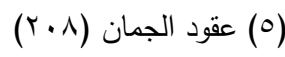

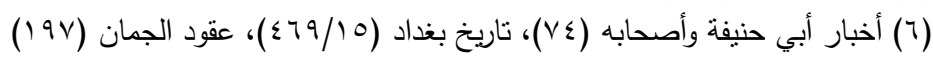


وتقى ثم حلف ألا يحدثهم شهراً(')

وقال خارجة بن مصعب، وأبو وهب العابد: من لا يرى المسح على بلى

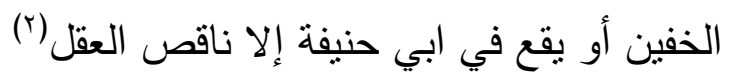
وقال ابن المبارك أيضاً: إذا رأيتهم يذكرون أبا لأبي حنيفة بسوء ساعني

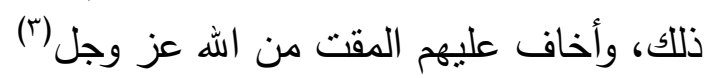

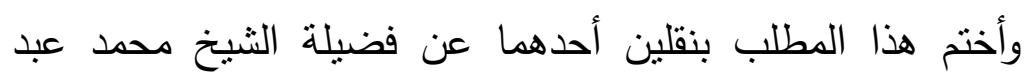

الرشيد النعماني: حيث قال: ثم قد أطبق الأئمة الحفاظ الذين جمعوا رجال

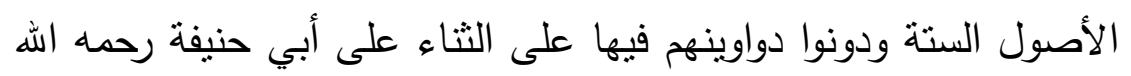
تعالى والتبجيل والتعظيم المفرط له دون الحط عليه والطعن فيه بسوء الحفظ والغفلة، بل إنهم بذكرون حفظه وجلالته في العلم، وبذكرونه بكل ونه

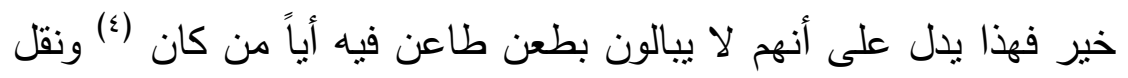

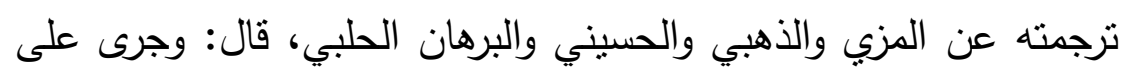

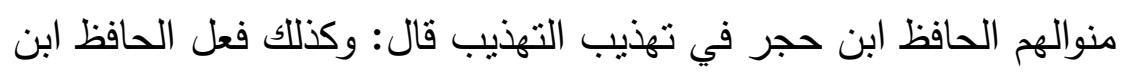
كثير في البداية والنهاية، وكذلك فعل صاحب المشكاة (الخطيب التبريزي)

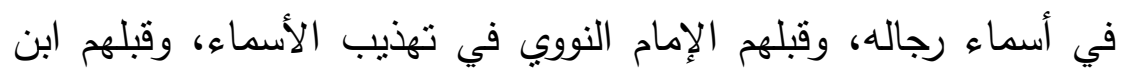
الأثثر في جامع الأصول، وقبل هؤلاء كلهم السمعاني في كتاب الأنساب قال: وعلى هذا المنوال جرى من أتى بعد هؤلاء العلماء الأكابر المذكورين الأهولئ

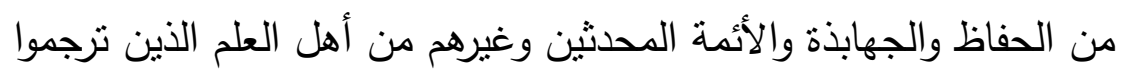

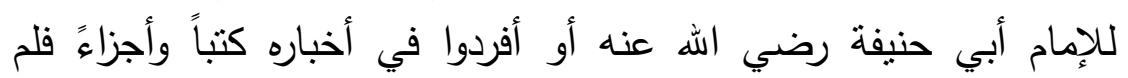
يذكروا شيئًا سوى فضائله، ومناقبه والثتاء عليه في دينه وورعه وسعة الهة

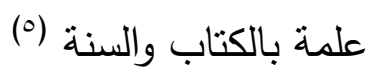

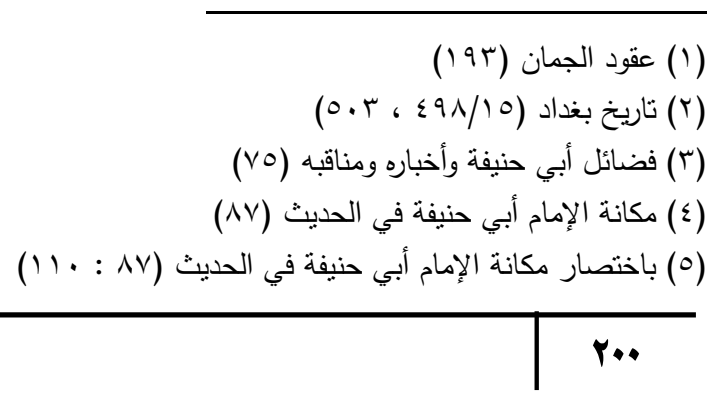




\section{نظرة منيفة إلى المكانة الحديثية للإمام الأعظم أبي حنيفة}

بل قد أثنى الذهبي على المزي حيث لم يورد في ترجمة أبي حنيفة

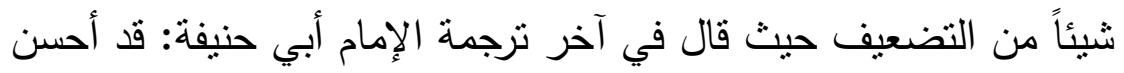

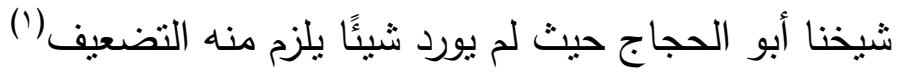

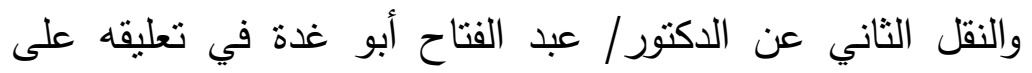

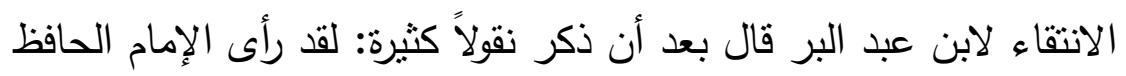

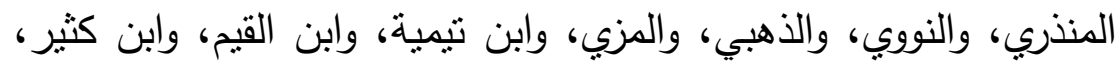

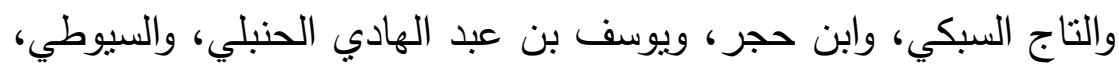

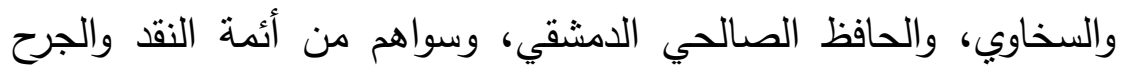

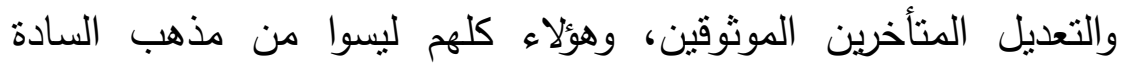

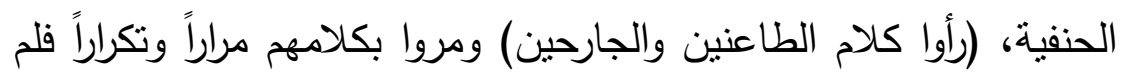

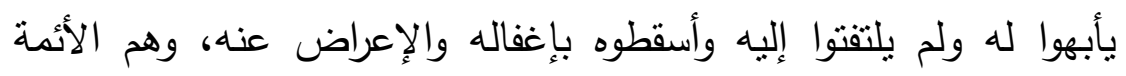

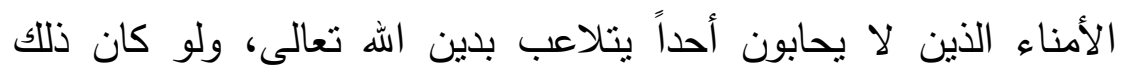

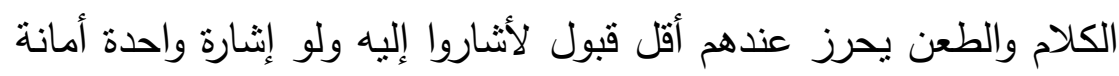

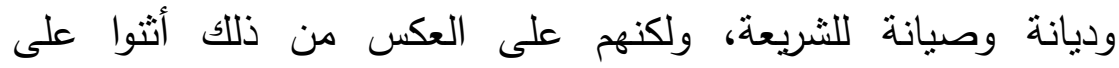

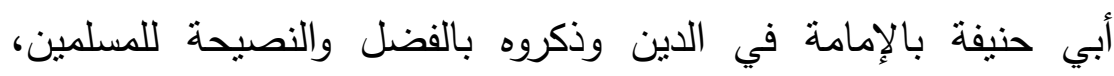

ووصفوه بأكرم التبجيل والتعظيم (؟) الاهانة فين

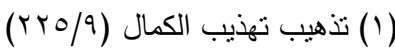

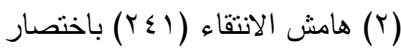




\section{البحث الرابع}

\section{أشياء يستدل بها على عظيم منزلة الإمام في علم الحديث}

وسوف أجعل هذا المطلب بعون الله في نقاط يستدل بكل واحدة

منها على عظيم قدر الإمام أبي حنيفة في علم الحديث الثريف

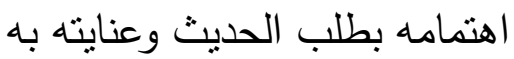

تقدم كثرة مشـايخه رضـي الله عنه واهتمامسه بطلب العلم والحديث

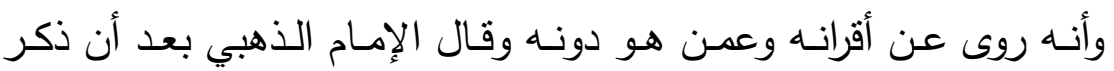

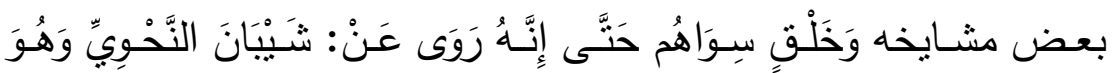

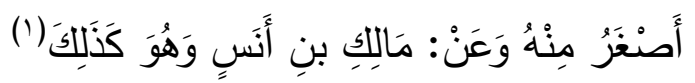
وقد سبق بيان كثرة رحلاته رضي الله عنه

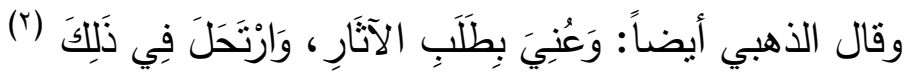
تثتبه فيما ينقل وكثرة حفظه

فهذا مسعر بن كدام (وهو من الثقات الأثبات الذي قال عنه ابن القطان: ما رأيت مثله كان من أثبت الناس) (r) يشهد للإمام أبي حنيفة بأنه أفضل منه في الحديث قال مسعر : طلبت مع أبي حنيفة الحديث فغلبنا، وأخذنا في الزهد فبرع علينا، وطلبنا معه الفقه فجاء ما ترون (ء) فإذا كان منل مسعر في حفظه وإتقانه الذي قيل عنه: إن شكه كيقين غيره يشهر بتقدم الإمام عليه في الحديث فهذا يدلك على أن الإمام بلغ الغاية من الحفظ والإتقان وكثرة الجمع للحديث

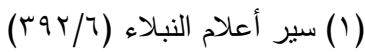

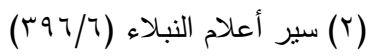

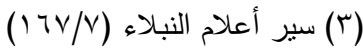

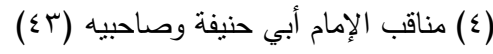




\section{نظرة منيفة إلى المكانة الحديثية للإمام الأعظم أبي حنيفة}

وكان متقدماً في تمييز الصحيح من غيره، ومعرفة ما يقبل وما يرد

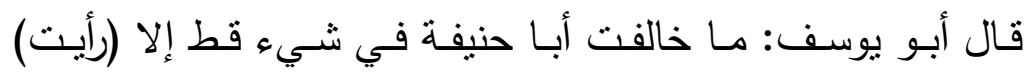
مذهبه الذي ذهب إلبه أنجى في الآخرة، وكنت ربما ملت إلى الحديث،

وكان هو أبصر بالحديث الصحيح مني (') وقـال أبـو يوسـف: كـان أبـو حنيفـة إذا وردت عليـه المسـألة قـال: ما عندكم فيها من الآثار؟ فإذا روينا الآثار وذكرنا وذكر هو ما عنده نظر

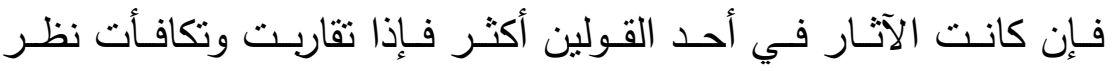
فاختار (r) وأرى أن مراده بالأكثريـة هنا القوة في الإسناد والسـلامة من العلل، ولذا قال: إذا تقاربت وتكافأت بعدها أي في القوة والاحتجاج كما أن ذكرهم لما عندهم من الأخبار وذكره بعد ذلك لما عنده إثنارة إلى زيادة علمه بالآثار فعنده زيادة على ما عندهم، فهو يغرب عليهم وكان قبـل ارتحالـه في الطلب قد أتقن حديث أهل بلده، وبـرع فيـه

$$
\text { عالماً بناسخ الحديث ومنسوخه }
$$

قال الحسن بن صالح: كان أبو حنيفة شديد الفحص عن الناسخ من الحديث والمنسوخ، فيعهل بالحديث إذا ثبت عنده عن النبـي صلـى الله

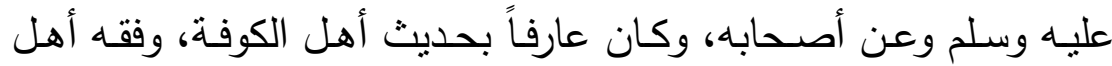
الكوفة شديد الاتباع لما كان عليه الناس بيلده وكان يقول: إن لكتاب اله ناسخاً ومنسوخاً، وإن للحديث ناسخاً ومنسوخاً، وكان حافظاً لفعل رسول الله صلى الله عليه وسلم الأخير الذي قبض عليه ممـا وصل إلى أهل 
بلده (')

وبشـهد لـه بذلك الإمـام سـفيان الثوري أبضـاً نقل ابن المبـارك عن

الثوري في قصة أن سفيان الثوري قال: كان أبو حنيفة شديد الأخذ للعلم، ذاباً عن حرم الله عز وجل أن يستحل، يأخذ بما صح عنده من الأحاديث. التي تحملها الثقات، وبـالآخر مـن فعل رسـول الله صـلى الله عليه وسـلم، وما أدرك عليه علماء الكوفة، ثم شنع عليه قوم نستغفر الله نستغفر الله(؟) فهو أثبـت معرفته بالصسحيح من غيره، وبـالرواة الثقات من غيرهم حتي يميز حديث هؤلاء وأولائك، وبالناسخ والمنسوخ ومن كثرة حفظه وشدة إتقانه وصف رحمه الله بأنه أحفظ أهل زمانه قال يزبد بن هارون (وقد سبق نقل ذلك عنه): كان أبو حنيفة تقباً نقياً زاهداً عالماً صدوق اللسان، أحفظ أهل زمانه، سمعت كل من أدركته من أهل زمانه يقول: إنه ما رأى أفقه منه (r) بل كان حفظه نافعاً للناس، فهو من أسباب حفظ السنن والفقه قال عبد الله بن داود الخربيجي: يجب على أهل الإسـلام أن بدعوا

الله لأبي حنيفة في صلاتهم، قال: وذكر حفظه علبهم السنن والفقه(ء) ولثـدة هـا الحفظ والإتقان وشـدة الالتزام بالسـنة والأثر قـال ابـن المبارك: قول أبي حنبفة عندنا كالأثر عن رسول الله صلى الله عليه وسلم إذا لم نجد أثراً(0) ولا عجب في ذللك فقد قال الإمام عن نفسـه: وَاعَجَبًا للِنَّاسِ، يَقُولُونَ:

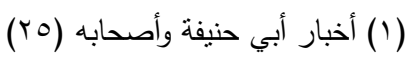

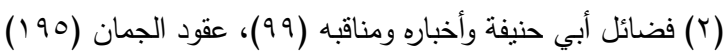

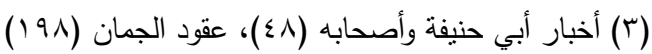

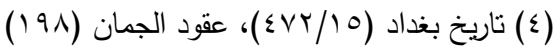

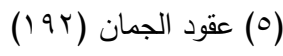




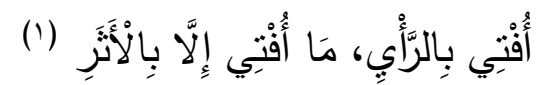
وذلك لأن ابن المبارك نفسه يقول: ما نكلم أبو حنيفة بشيء إلا بحجة من كتاب الله أو سنة نبيه صلى الله عليه وسلم(ب)

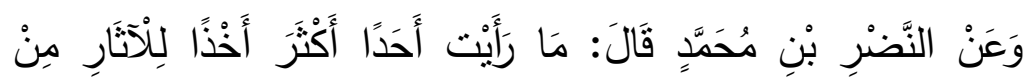
أَبِي حَنِيفَةَ وَعَنْ يَحْيَى بْنِ نَصْرِ قَالَ سَمِعْت أَبَا حَنِيفَة يَقُولُ عِنْدِي صَنَادِيقُ مِنْ

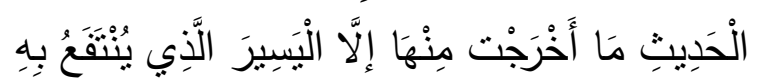

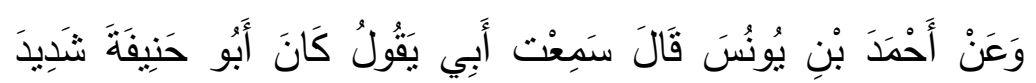

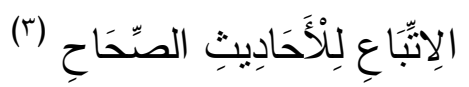

بل قال الإمام أبو حنيفة عن نفسه: إني لأروى الناس للحديث(ء) معنى كون الإمام أبي حنيفة رحمه الله إمام أهل الرأي وأصحابه الإنيه أصحاب الرأي

يفسر ذلك الإمام ابن حجر الهيتمي في الخيرات الحسان فيقول:

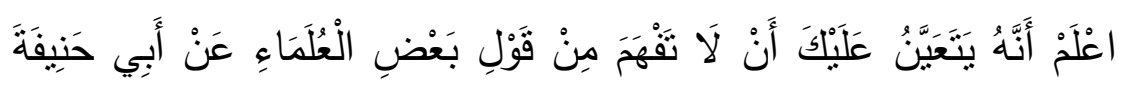

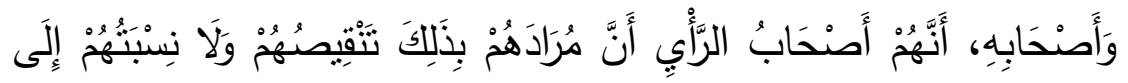

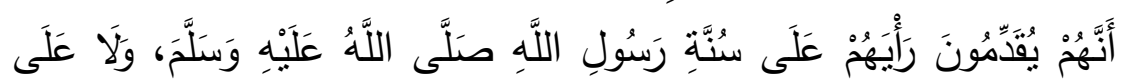

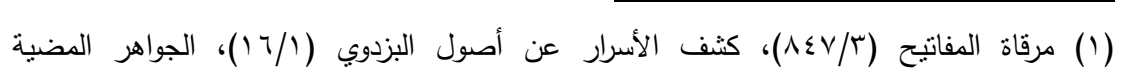
$(r \cdot r / Y)$

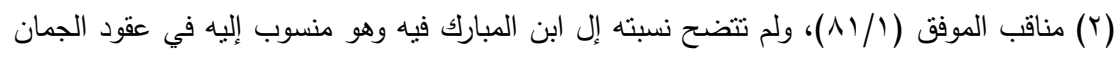

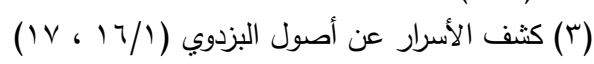

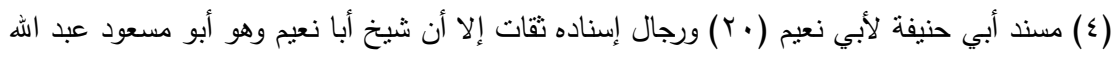

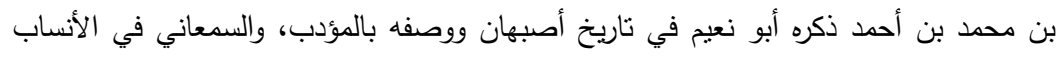
ونسبه النقاط ولم أر فيه جرحاً ولا تعديلاً

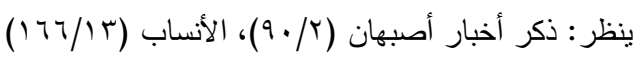




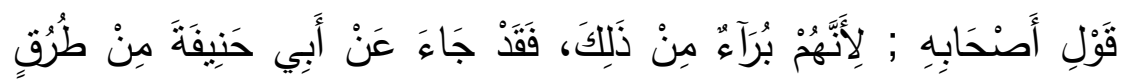

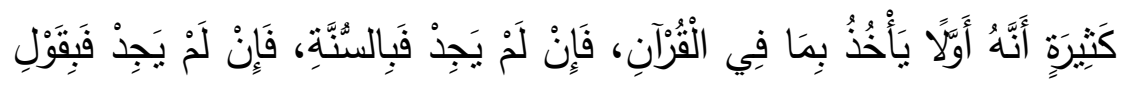

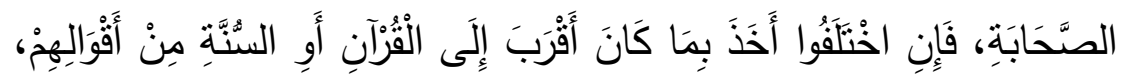

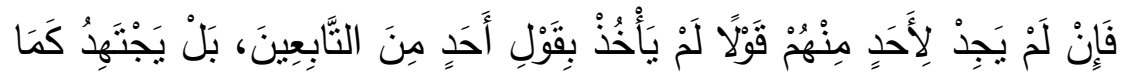

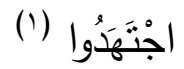

وقد بين ذلك البزدوي في أصوله فقال: وَهُمْ أَصْحَابُ الْحَدِيثِ

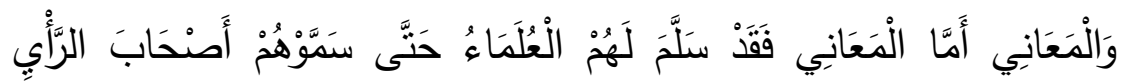

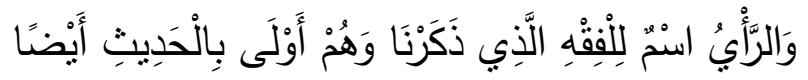

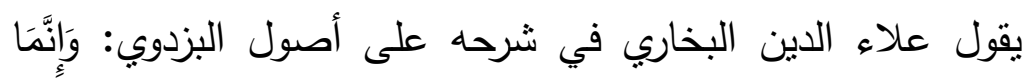

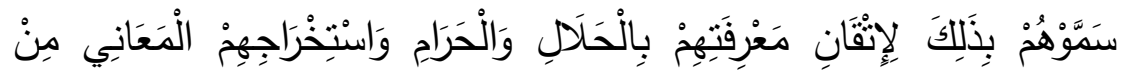

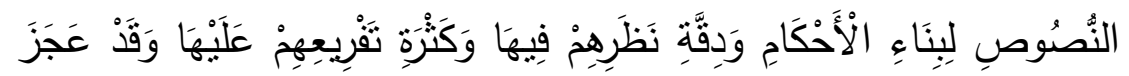

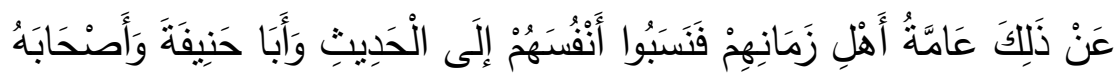

إلَى الرَّأْيِ

ويبين الإمام البزدوي وجه كون أصحاب أبي حنيفة أولى بأن يكونوا

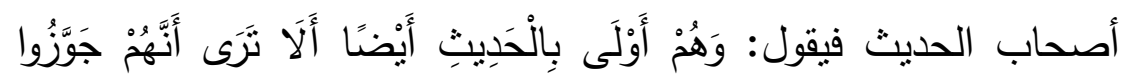

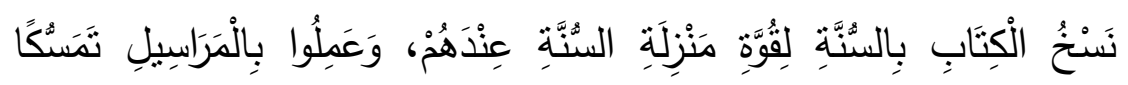

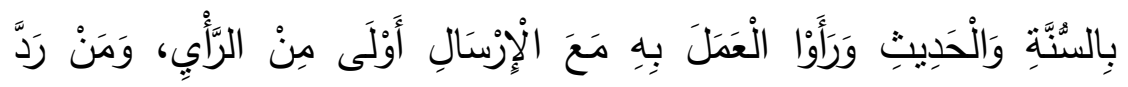

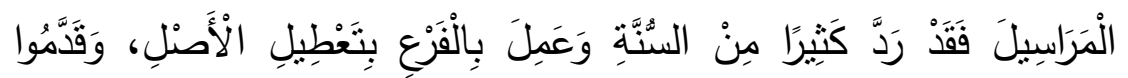

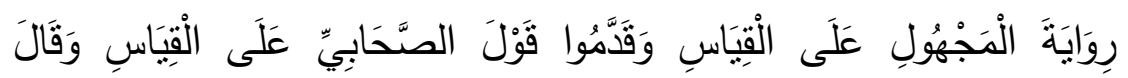

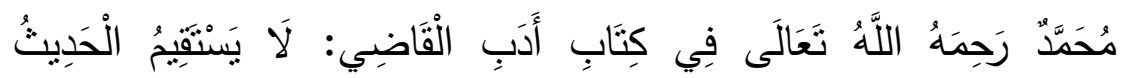

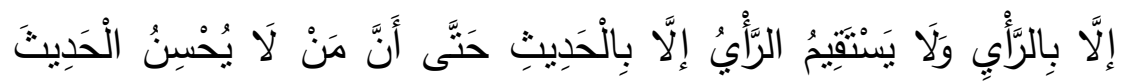

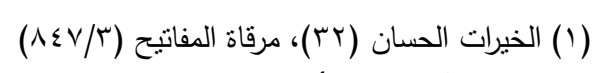

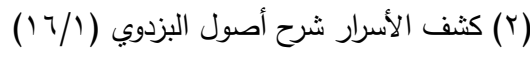




\section{نظرة منيفة إلى المكانة الحديثية للإمام الأعظم أبي حنيفة}

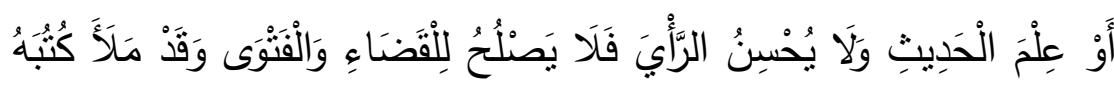

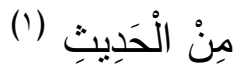

رجوع إلى وصف الإمام بثدة الحفظ

قال إسرائيل بن يونس: نعم الرجل النعمان، ما كان أحفظه لكل

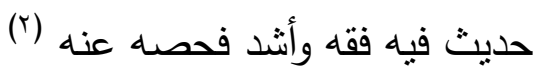

وقال أبو يوسف: ما رأيث أحدا أعلم بتفسير الحديث ومواضع

النكت التي فيه من الفقه من أبي حنيفة (r)

وقال أيضاً: كنا نكلم أبا حنيفة في باب من أبواب العلم، فإذا قال القال

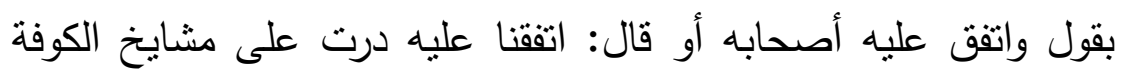

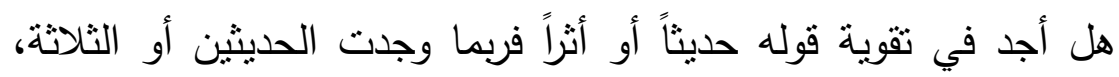

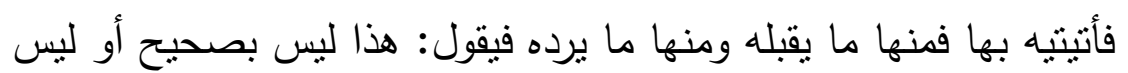
بمعروف وهو يوافق قوله، فأقول له: وما علمك بذللك؟ فيقول أنا عالم بعلم

أهل الكوفة (₹)

\section{ومن كثرة حفظه وحديثه وسرده له للاستدلال:}

ما جاء أنه كان عند الأعش فسئل عن مسائل فقال لأبي حنيفة:

ما تقول فيها؟ فأجابه، قال: من أين للك هذا؟ قال من أحادينك التي رويتها عنك وسرد له عدة أحاديث بطرقها، فقال الأعمش: حسبك ما حدثلك به لهابه في مائة يوم تحدثي به في ساعة واحدة ما علمت أنك تعمل بهذه الأحاديث با معشر الفقهاء أنتم الأطباء ونحن الصبادلة، وأنت أيها الرجل

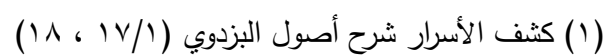

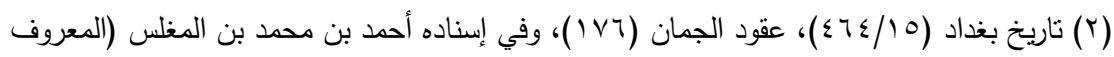

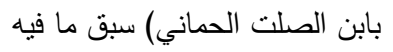

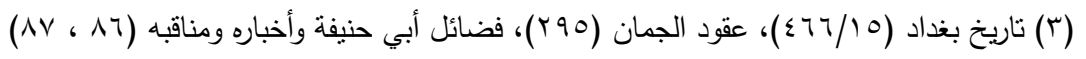

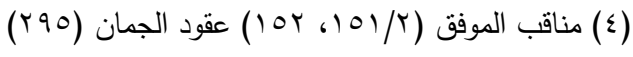




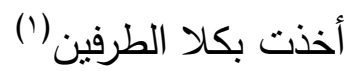

وكان حديثه مما يحرص المحدثون على جمعه

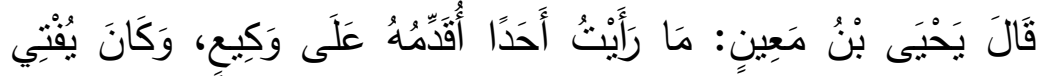

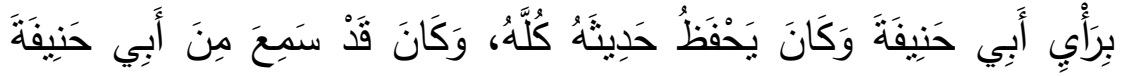

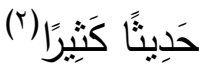

وقد أفاد هذا النص كثرة حديث أبي حنيفة، وأنه مما يجمع ويهنم به المحدثون، وأن وكيعاً اهتم بحفظه، فحفظ كل ما سمع وما سمعه كثير

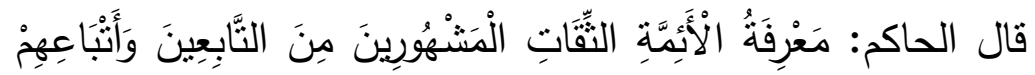

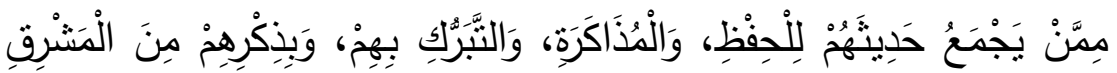

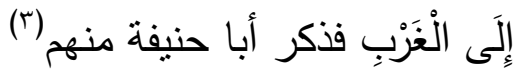
وكان معظماً عند أهل الحديث من مشايخه فمن دونهم فهذا شعبة يكتب إليه أن يحدث كما سبث عن ابن معين، ويكتب له اهله أيضاً في شأن بعض أهل العلم ممن يقدم عليه الكوفة (أبو قطن عمرو بن الهيثم) فيقول أبو حنيفة بعد أن يقرأ الكتاب: ما عندنا للك مبذول وما

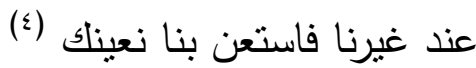

وقال حماد بن زيد: ما عرفنا كنية عمرو بن دينار إلا بأبي حنيفة

كنـا فـي المسـجد الحـرام وأبـو حنيفـة مـع عمـرو بـن دينـار فقلنـا لـه:

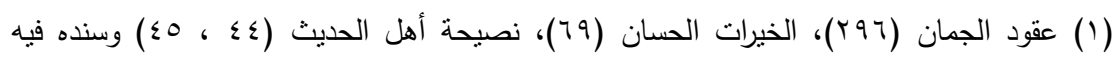

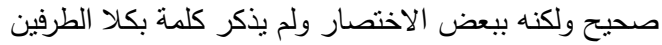

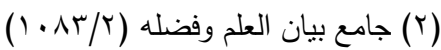

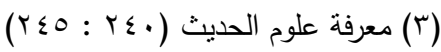

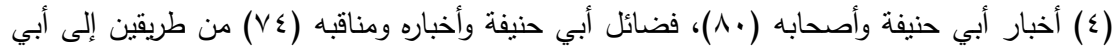

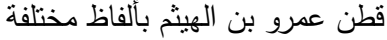




\section{نظرة منيفة إلى المكانة الحليثية للإمام الأعظم أبي حنيفة}

با أبا حنيفة كلمه يحدثا فقال: با محد حدثهم ولم بقل: يا أبا محمد (') وفي رواية عن حماد بن زيد: كنا نأني عمرو بن دينار فيحدثا فإذا إنا

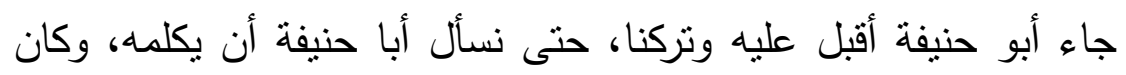

يقول يا أبا محمد حدثهم فيحدثنا (r) ولذلك كان بعرف أهم تلاميذ عمرو بن دينار وأتقنهم لحديثه فأرشد

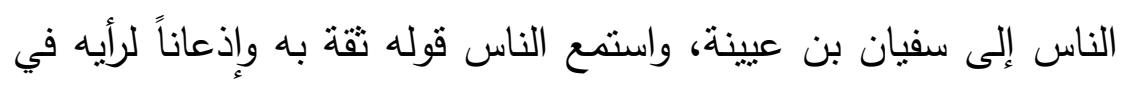

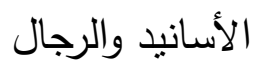

قال سفيان بن عيينة: أول من أجلسني في الحديث أبو حنيفة، قيل:

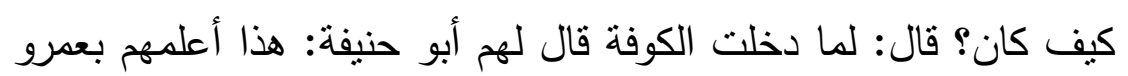

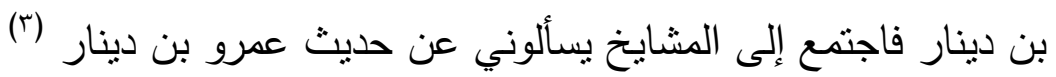
وقد سبق هذا النقل عن سفيان من لفظ الانتقاء لابن عبد البر، وقد

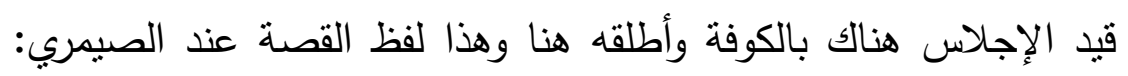
أول من أجلسني في الحديث هكذا مطلقاً

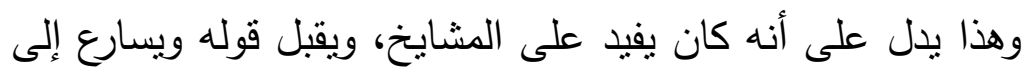

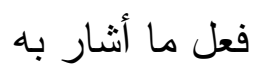

وقال الحارث بن عبد الرحمن: كنا نكون عند عطاء بعضنا خلف

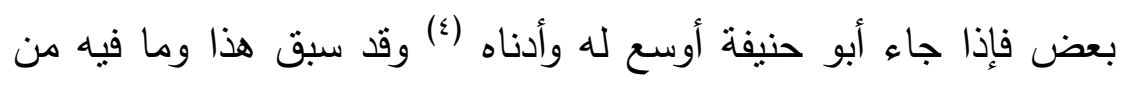
دلائل في رحلات الإمام رحمه الله

وقال أبو حنيفة عند نفسه: فجلست إلى حماد (بن أبي سليمان)

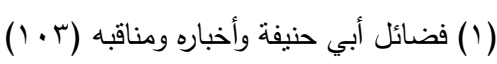

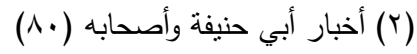

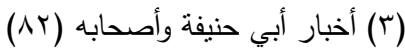

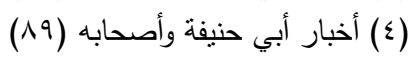


فكنت أسمع مسائله فأحفظ قوله ثم يعيدها من الغد فأحفظها ويخطئ

أصحابه فقال: لا يجلس في صدر الحلقة بحذائي غير أبي حنيفة (') وهذا كما يدل على شدة الحفظ وقوته وإتقانه يدل على تعظيم حماد

لأبي حنيفة رحمهما الله ورضي عنهما بل كان يناقش حماد في المسائل ويشتد النقاش فإذا انصرف أبو حنيفة قال حماد: هذا مع فقهه يحيى الليل ويقومه، وفي رواية أخرى: يقوم (r) الليل ويحييه وقال حماد بن زيد: كان جرير بن عبد الحميد خالفني في شيخ، فسألت أبا حنيفة عنه فتابعني على قولي، وقال لي أصحابه: إنه يروي عن هذا الثيخ (广) قال زفر : كان كبراء المحدثين مثل زكريا بن أبي زائدة، وعبد الملك بن أبي سليمان، والليث بن أبي سليم، ومطرف بن طريف، وحصين بن

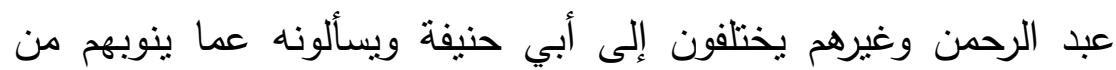

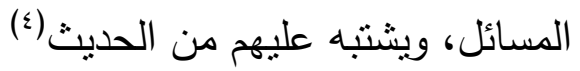




\section{نظرة منيفة إلى المكانة الحليثية للإمام الأعظم أبي حنيفة}

\section{البحث الخامس}

\section{كثرة حديثه والمساتيد التي رويت عنه رحمه الله}

ومما يدل على تقدم الإمام في علم الحديث كثرة حديثه وقد سبق أن حديث الإمام مما يجمع للحفظ والمذاكرة والتبرك وأنه مما حرص عليه المحدثون وإنما يجمع الثيء إذا كان كثيراً وقال الحافظ الصالحي الثامي في عقود الجمان: الباب الثالث والعشرون في بيان كثرة حديثه وكونه من أعيان الحفاظ المحدثين، والرد على من زعم قلة اعتائه بالحديث، وبيان المسانيد التي خرجها له الحفاظ من حديثه.. ثم قال: اعلم رحمك الله تعالى أن الإمام أبا حنيفة رحمه الله تعالى من كبار حفاظ الحديث، وقد تقدم أنه أخذ عن أربعة آلاف شيخ من أئمة التابعين وغيرهم، وقد ذكره الحافظ الناقد أبو عبد الهه الذهبي في كتابه الممتع في طبقات الحفاظ من المحدثين، ولقد أصاب وأجاد، ولولا كثرة اعتتائه بالحديث ما تهيأ له استتباط مسائل الفقه، فإنه أول من استتبطه وله من الأدلة، وعدم ظهور حديثه في الخارج لا بدل على عدم اعتتائه بالحديث كما زعمه بعض من يحسده، وليس كما زعم، وإنما قلت الرواية عنه وإن كان متسع الحفظ لأمرين: أحدهما اشتغاله عن الرواية باستتباط المسائل من الأدلة كما كان أجلاء الصحابة كأبي بكر وعمر رضي الله عنهما يشتغلون بالعمل عن الرواية حتى قلت روايتهم بالنسبة إلى كثرة

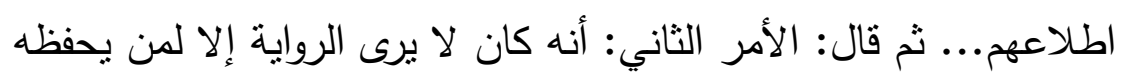

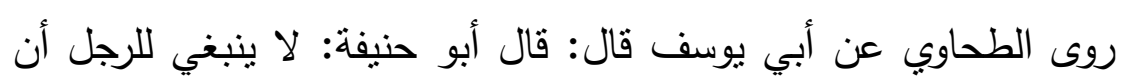

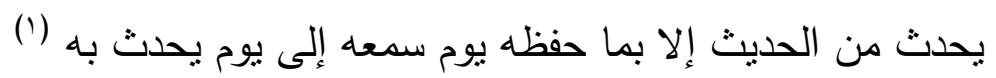

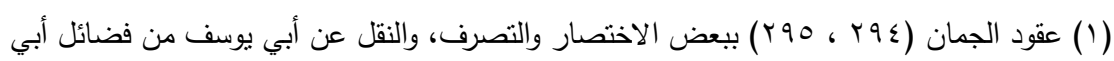

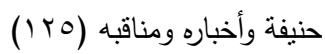


وقال الإمام الكوثري تعقيبا على وصف الإمام بأنه يتيم في الحديث أو مسكين في الحديث: على تقدير ثثوت ذللك يكون الواصف أراد قلة عناية أبي حنيفة بإكثار الطرق، في رواية الحديث كما هو شأن المتفرغين للرواية بخلاف المجتهدين المنصرفين إلى استنباط الأحكام، وكان إبراهيم بن سعيد الجوهري يقول: كل حديث لم يكن عندي من مائة وجه فأنا فيه إيه وائ يتيم ونعتزف أن أبا حنيفة لم يكن من هذا الطراز ولا من رواة مئات الألوف من الحديث، وإنما كان عنده صناديق من الحديث انتقى منها أربعة آلاف حديث نصفه من حماد بن أبي سليمان شيخه الخاص الذي به تخرج، ونصفه الآخر من باقي شيوخه.. ثم قال: ومن ظن بأبي حنيفة أنه قليل الحديث أو كثير المخالفة للحديث، أو كثير الأخذ بالأحاديث الضعيفة جهل ذلك كله، وجهل شروط قبول الأخبار عند الأئهة، ووزن بأن التهن

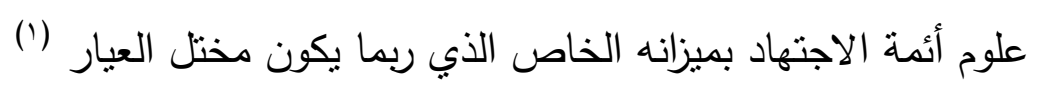
أقول: روى الطحاوي عن بكار بن قتيبة سمعت أبا عاصم النبيل

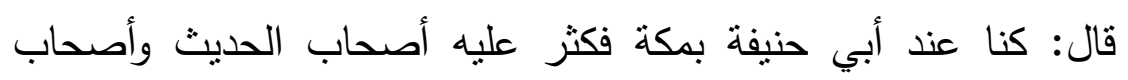
الرأي أي يسألونه فقال: ألا رجل يذهب إلى صاحب الربع (المنزل) حتى يفرق عنا هؤلاء فقلت له: أنا أذهب ولكن بقي معي مسائل أحب أن أسأل عنها (r) وهذا دليل على تقدمه في الحديث والفقه وكثرة حديثه فإن أصحاب الحديث يجتمعون ويكثرون ليسألوا عن الحديث والإمام خارج وطنه

قال يحيى بن نصر بن حاجب: سمعت أبا حنيفة رحمه الله يقول: 


\section{نظرة منيفة إلى المكانة الحديثية لإمام الأعظم أبي حنيفة}

عندي صناديق من الحديث ما أخرجت منها إلا اليسير الذي ينتفع به(') وفي المناقب للموفق: وانتخب أبو حنيفة رحمه الله الآتار من أربعين

(ألف حديث

وقد سبق النقل عن الإمام رضي الله عنه أنه قال إني لأروى الناس

للحديث

ومن الذي يدل دلالة واضحة على كثرة حديث الإمام وكثرة اعتتائه

بالحديث ما جُمِع له من مسانيد زادت على السبعة عثر مسنداً وقد جمع منها أبو المؤيد الخوارزمي خمسة عشر مسنداً في كتاب

سماه جامع المسانيد ورتبه على أبواب الفقه وقال في مقدمته وقد سمعت بالثام بعض الجاهلين .. من ينسب الإمام إلى قلة رواية الحديث ويستدل باشتهار المسند الذي جمعه أبو العباس محمد بن بعقوب الأصم للثافعي وموطأ ماللك ومسند أحمد رحمهم الله تعالى وزعم أنه ليس لأبي حنيفة مسند وكان لا يروي إلا عدة أحاديث فلحقتتي حمية دينية ربانية وعصبية حنيفية نعمانية(r) فأردت أن أجمع بين خمسة عشر من مسانيده التي

جمعها له فحول علماء الحديث ثم ذكـر المسـانيد الخمسـة عشـر وهـي (1) أبـو محمــ الحـارثي البخـاري (Y) طلحة بـن محمد بـن جعفر الثـاهد العدل (r) أبو الخير محمد بن المظفر (ع) أبو نعيم الأصبهاني (0) أبو بكر محمد بن عبد

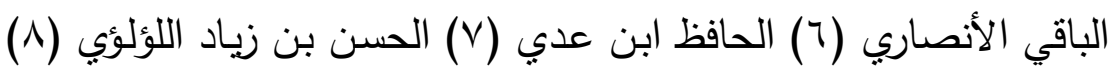

(1) (1) (9ناقب الموفق (190/1، (90/1)

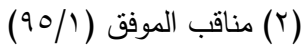
(r) هذا ليس من التعصب المذهبي بدليل قوله قبل ذلك حمية دينية ربانية، فالتعصب هنا تعصب للحق حتى ينتصر لأهله

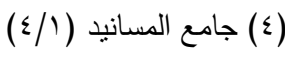


عمر بن الحسن الأشناني (9) أبو بكر الكلاعي أحمد بن محمد (· ( )

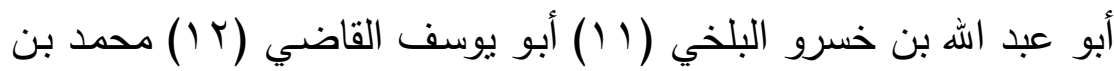
الحسن (T) (1) حماد بن أبي حنيفة (ع () محمد بن الحسن أيضـاً ونسخته

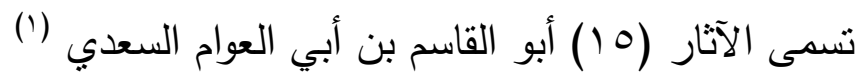

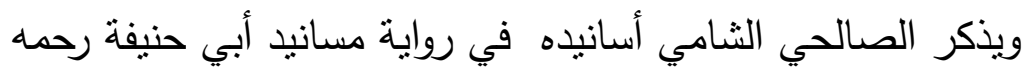

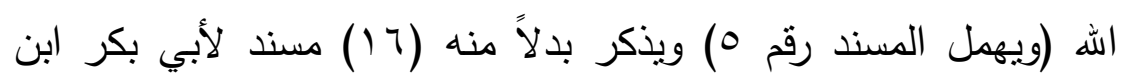
المقري ، (V) ومسند لأبي علي البكري وقد ذكر الإمام الكوثري أسانيده إلى ثلك المسانيد ثم قال: بل كان الخطيب نفسه حينما رحل إلى دمثق استصحب معه (1/) مسند أبي حنيفة للدارقطني، (9 1 ) ومسنده لابن شاهين وهذا غير تلك المسانيد السبعة عشر قال الكوثري: وذكر البدر العيني أن (·r) مسند أبي حنيفة لابن عقدة يحتوي وحده على ما يزيد على ألف حديث وهو أيضاً غير تلاك (r) المسانيد فهذه عشرون مسنداً للإمام رحمه الله تعالى وقد يزيد الأمر عن ذلك قال الكوثري: وما عنده من أحاديث الأحكام المروية في المسانيد من غير تكرير للمنن، ولا سرد للطرق عن حديث واحد مقدار عظيم لا بيتقله من

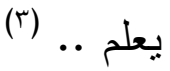
فالثيخ يتكلم عن كثرة أحاديث الأحكام المروية في هذه المسانيد فما باللك بغيرها كل ذلك بدون تكرار للطرق ولا جمع للروايات

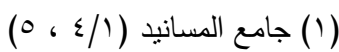

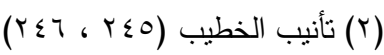

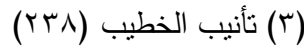


الخاتمة نسأل الله عز وجل حسنها

وتثتثمل على وفاة الإمام، وأهم نتائج البحث

وفاة الإمام رحمة الله ورضي عنه ونفعنا به ويعلومه في الدارين آمين

بعث المنصور إلى الإمام أبي حنيفة يستدعيه وعرض عليه القضاء

فأبى وقد اتفق الرواة على أنه حبس، وأنه لم يجلس للإفتاء والتذريس بعد الإمان ذلك، وتكاد الروايات تتفق على أنه ضرب، لكنها تختلف أمات محبوساً بعد الضرب، أم محبوساً بالسم فلم يكتف بالضرب بل سقي السم ليعجل موته، أم أطلق من حبسه فمات بعد المحنة بقليل؟ قال الخطيب: والصحيح أنه مات وهو في السجن(') والرواة متفقون على أنه أوصى أن يدفن في جانب من المقبرة لم يجر فيه غصب دون الجانب الآخر لأنه غُصِبَ مات رحمه الله تعالى في عام ،10 على الصحيح وقيل في تحديد السنة غير ذللك، قيل: في رجب وقيل: في شعبان وقيل: في شوال

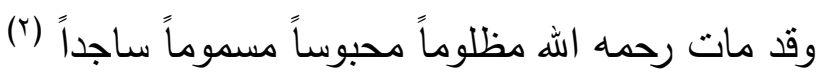

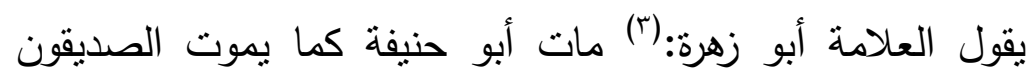
والثهداء، وقد كان في الموت راحة لذلك الضمير المُعَنَّى، ولذلك الوجدان الديني المرهف، ولذلك القلب القوي، ولذلك العقل الجبار، ولتلك النفس

$$
\text { الصبور التي لاقت الأذى فاحتملته، }
$$

لاقته من المخالفين في الآراء، ورميت بكل رمية فتحملتها مطمئنة راضية مرضية، ولقيت الأذى من السفهاء، ثم لقيته من الأمراء، ثم

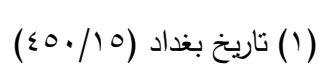

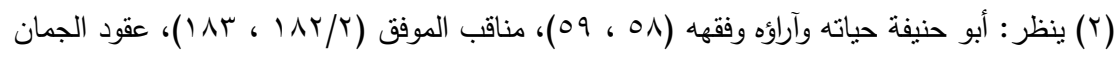

(r) (广) أبو حنيفة حياته آراؤه وفقهه (1) (09) 
الخلفاء، وما ضعفت وما وهنت

واذا كان للنفوس جهاد، ولجهادها ميادين، فأبو حنيفة رضي الله

عنه كان من أعظم أبطال ذلك النوع من الجهاد، وممن انتصر في كل ميادينه، وكان جلداً في جهاده قوباً في جلاده، حتى وهو يلفظ النفس الأخير، فهو يوصي بأن بدفن في أرض طيبة لم يجر عليها غصب، وألا بدفن في أرض قد اتهم الأمبر بأنه غصبها

قال: ولعظمة الدين والعلم والخلق روعة وتأثير في الناس لا يقل عن عظمة السلطان وجاه الحكام، ولذلك شبعت بغداد كلها جنازة فقيه

العراق والإمام الأعظد. أ..هـ

\section{أهم نتائج البحث، وتوصياته}

ا. ينبغي على المجتمع عموماً والعلماء خصوصاً أن يوفروا البيئة العلمية المناسبة لأهل العلما فلقد رأينا كيف أثرت البيئة العلمية الخاصة والعامة في الإمام أبي حنيفة في شخصيته وفي تكوينه العلمي فزادته قوة في العلم وحرصا عليه وتتوعاً فيه الإنه r. كما أن بستدل بكثرة شيوخ الإمام وتتوعهم حتى بلغوا أربعة آلاف شيخ على مزيد الاهتمام بالعلم عموماً وبعلم الحديث خصوصاً ". وبستفاد من كثرة رحلاته تتوع المشارب والمعارف التي ينهل منها الإمام فهو لم بجعل نفسه محصوراً في دائرة معينة بل كان برتحل الكثير من الرحلات، متعلماً ومعلماً

ع. ومع علو سند الإمام وإدراكه لزمن الصحابة ورؤيته لبعضهم على الأقل فهو مسن التـابعين فإنـه يـروي عمن هـو مثلهـه وعمن هـو دونـه شـأن المحدثين المتقنين ه. وقد كون الإمام منهجاً جديداً في درسه مع طلابه بل وأصحابه على 


\section{نظرة منيفة إلى المكانة الحديثية للإمام الأعظم أبي حنيفة}

نحو من الثورى يأتي كل منهم برأيه ودليله فيتتاقشون حتى ينتهوا إلى

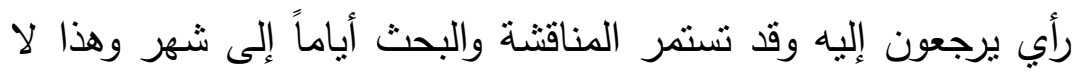
شك بمنع كثيراً من الوقوع في الخطأ حديثياً وفقهياً T. ولقد ذكر ابن عبد البر (T/) عالماً ممن أنثى على الإمام بعبارات مختلفة وروايات متعددة زادهم الثيخ عبد الفتاح أبو غدة اثثين فصار المجموع ( • V)(') وإذا ندبرت الذي ذكرناه وجدت الأمر أكثر من ذلك ألك 7. ولقد تتوعت ألفاظ وعبارات التعديل في حق الإمام صراحة من وصفه بأعلى درجات التوثيق، ونحو ذلك V. كما ينبغي ألا نهمل الأمور والدلائل الأخرى التي يستتبط منها الإنسان إذا تأمل مزيد إتقان الإمام لعلم الحديث، وتقدمه فيه، وتعظيمه لسنة سيدنا رسول الله صلى الله عليه وسلم والحمد له أولاً وآخراً وصلى الهه وسلم وبارك على سيدنا محمد وعلى وسلى آله وصحبه أجمعين 
قائمة المصادر والمراجع

\begin{tabular}{|c|c|c|}
\hline لبعة & رُلف & كتاب \\
\hline 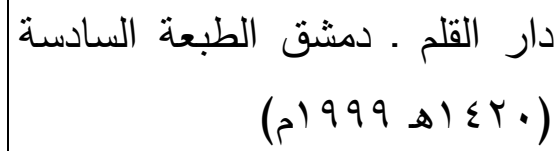 & & مام الأئمة الفقهاء النعمان \\
\hline 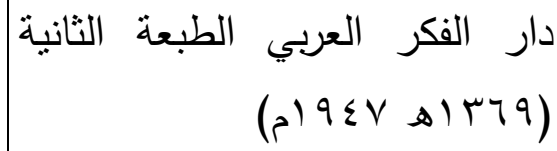 & محمد أبو زهرة & وعصره \\
\hline 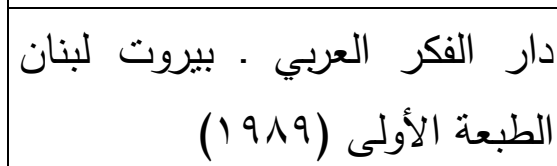 & |الكيرانوي & حنيفة وأصحابه \\
\hline 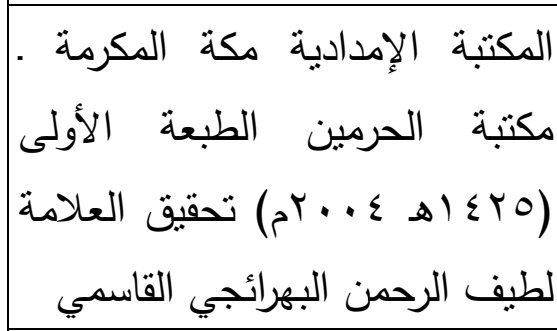 & أبو & الأحاديث \\
\hline 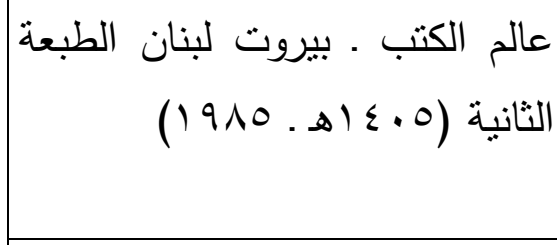 & أبو عبن الله & 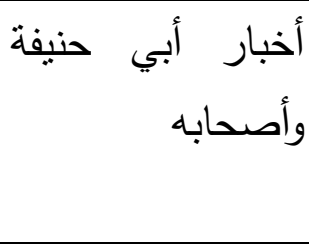 \\
\hline & & لآداب للبيهقي \\
\hline 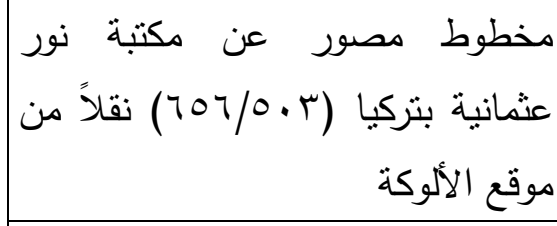 & |الحسين & سماء رجال المشكاة \\
\hline تشقيق مكتب المطبوعات الإسلامية & |أبو & 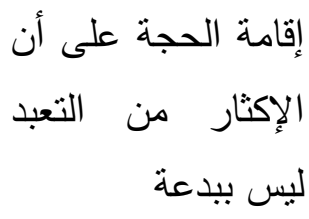 \\
\hline
\end{tabular}


نظرة منيفة إلى المكانة الحديثية للإمام الأعظم أبي حنيفة

\begin{tabular}{|c|c|c|}
\hline & & \\
\hline 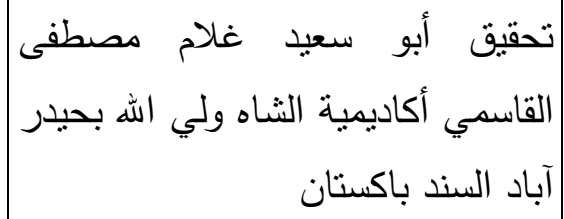 & محمد & رح نحبة النظر شرح \\
\hline مطبعة الأنوار (• بسإهـ) تعليز & سبط & ذذهب الصحيح \\
\hline 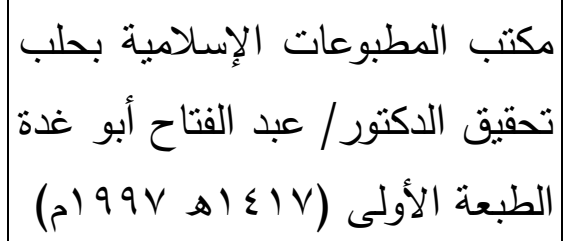 & الحافظ & إنتقاء في فضائل \\
\hline طبعة مجلس دائرة المعارف العثمانية & محمد السمعاني الكريم بن & \\
\hline 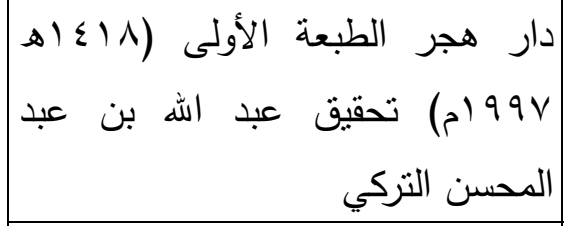 & أبو & \\
\hline 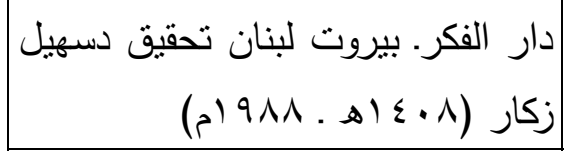 & 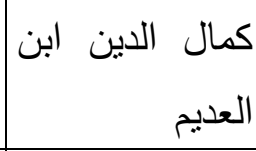 & غيخة الطلب \\
\hline 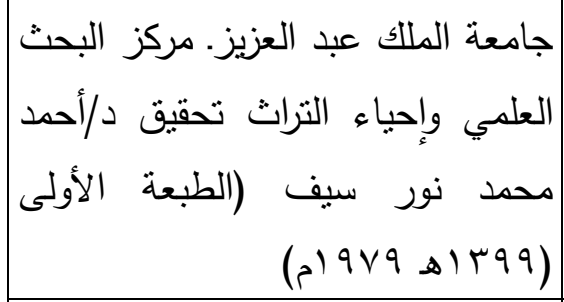 & |لدواية بن & ريخ ابن معين \\
\hline ية. تحقيق صحبي السامرائُ & شأبو هف ابن & ريخ اسماء النقات \\
\hline
\end{tabular}




\begin{tabular}{|c|c|c|}
\hline الطبعة & |المؤلف & اسم الكتاب \\
\hline عار الغرب الإسلامي ـ تحقيق بشار & | شمس & لإسلام \\
\hline دار الكتب العلمية ـ بيروت ـ لبنان & 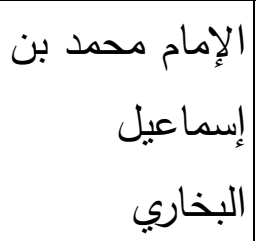 & 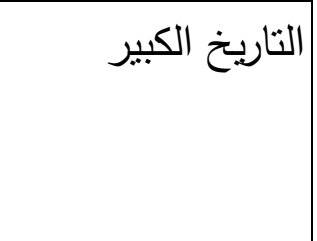 \\
\hline 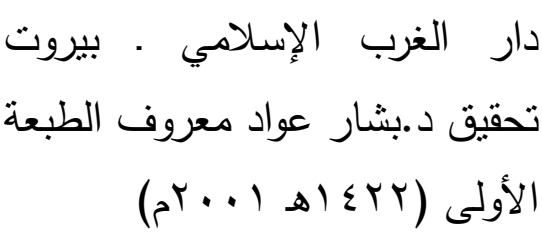 & بأحمد بن & 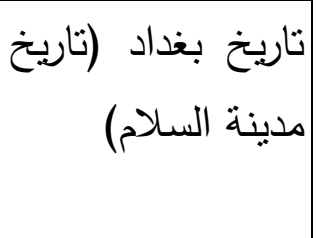 \\
\hline تحقيق عمر بن غرامة الفكر للطباعة والنشر والتوزيح & |ٔبو القاسم ابن & بِخ دمشق \\
\hline المكتبة الأزهرية للتراث & | محمد زاهد بن & يب الخطيب \\
\hline 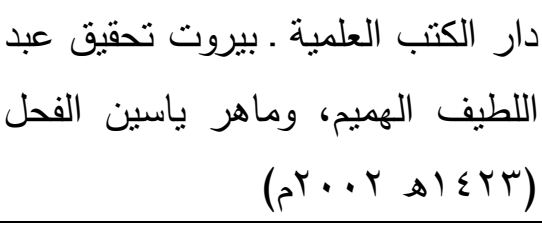 & |الحافظ العراقي & لتبصرة والتذكرة \\
\hline 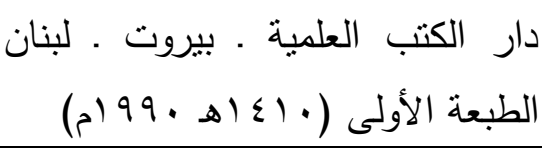 & الحافظ & تبيضيض أبي حنبفة \\
\hline 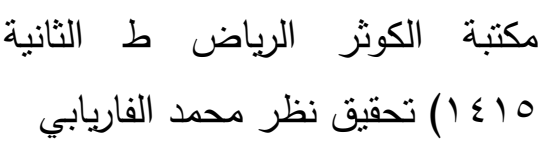 & الدافظ & بيب الراوي \\
\hline
\end{tabular}


نظرة منيفة إلى المكانة الحليثية للإمام الأعظم أبي حنيفة

\begin{tabular}{|c|c|c|}
\hline الطبعة & المؤلف & اسم الكتاب \\
\hline 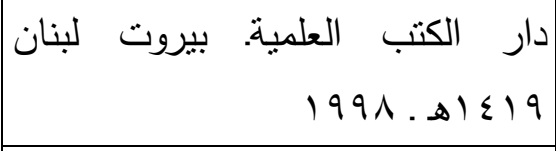 & |الحافظ & ة الحفاظ \\
\hline 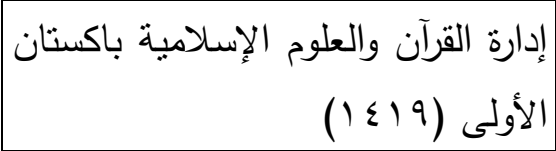 & 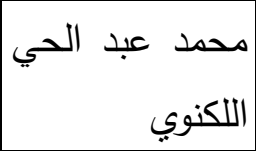 & تذكرة الراشد \\
\hline 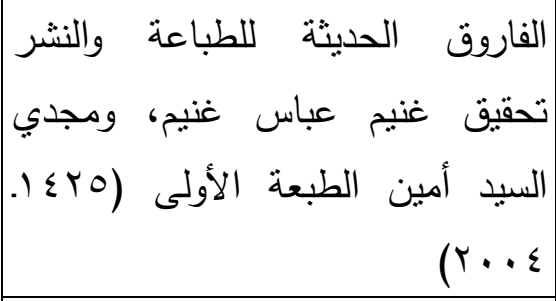 & |الدافظ & يب تهذيب الكمال \\
\hline وزارة الأوقاف المغربية. تحقيق محمد & |اضقي عياض & يب المدارك \\
\hline شدار الكتب العلمية تحقيق إبراهيم & | عبد & زغيب والترهيب \\
\hline إدارة المطبعة المنيربة & \begin{tabular}{|l|}
$\mid$ شرف الإمام يحيى بن النووي \\
\end{tabular} & تهذيب \\
\hline 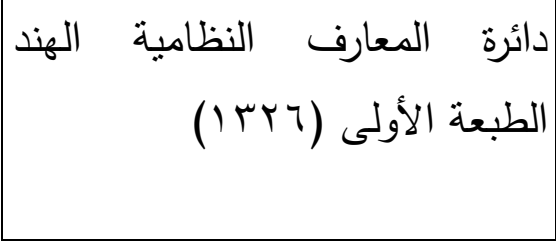 & $\begin{array}{r}\text { الحافظ } \\
\\
\text { ابن } \\
\text { العسقلاني }\end{array}$ & هذيب التهذيب \\
\hline مؤسسة الرسالة . بيروت تحقيق & |الحافظ & تهذيب أسماء الرجال في \\
\hline
\end{tabular}




\begin{tabular}{|c|c|c|}
\hline طبعة & ولع & م الكتاب \\
\hline 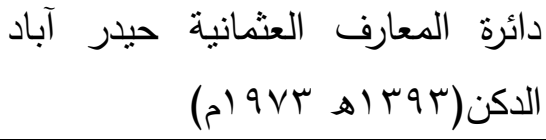 & أبو & \\
\hline البيان تحقبة الملاح . مكتبة الحلواني . دار عبد القادر الأرناؤوط & 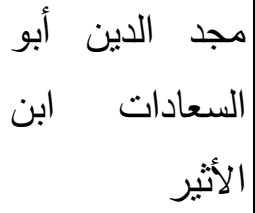 & الأصول \\
\hline 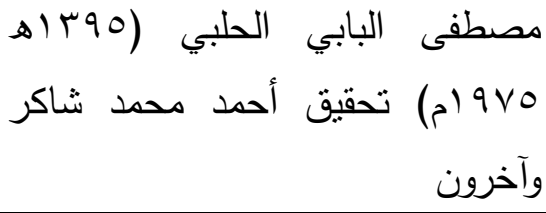 & بحمد بن عبسى & ع الترمذي \\
\hline دائرة المعارف حيدر آباد الدكن & أبو المؤبد محمد & (جامع \\
\hline دار الأثبال الزهيري الجوزي ـ السعودية تحقيق أبو & 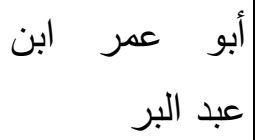 & وفضل \\
\hline 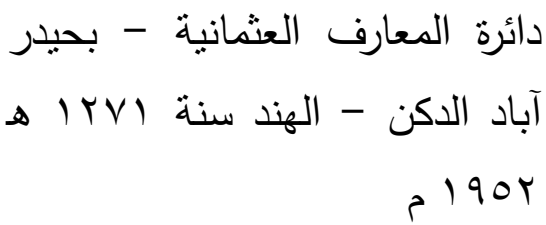 & 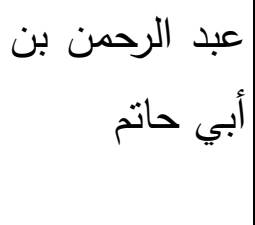 & والتعديل \\
\hline دار هجر. تحقيق عبد الفتاح محمد & عحبي & الجواهر المضية \\
\hline مطبعة السعادة مصر ( ؟ ب I) & الحافظ & أخيرات الحسان في الإن الإمام الأعظم \\
\hline
\end{tabular}


نظرة منيفة إلى المكانة الحليثية للإمام الأعظم أبي حنيفة

\begin{tabular}{|c|c|c|}
\hline الطبعة & كُلف & 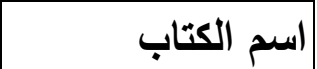 \\
\hline دار الكتب العلمية ـ بيروت & |أبو بكر البيهقي & ة للابن. \\
\hline دار الكتاب الإسلامي & |أبو & بار أصبهان \\
\hline 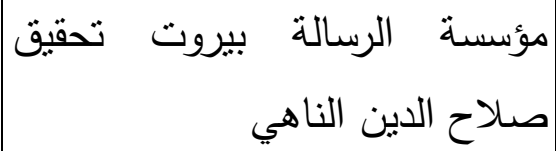 & |أبو القاسم ابن & نـة القضناة \\
\hline المكتب الإسلامي & |لسباعيى & شنة ومكانتها في \\
\hline المكتبة العصرية ـ تحقيق محد & \begin{tabular}{|l} 
الإمام أبو داود \\
الأشعانث \\
بن
\end{tabular} & ن أبي داود \\
\hline خالد الجراف د.سعد عبد الله الحميد، ود. & |أبو عبد الرحمن| & إلات \\
\hline 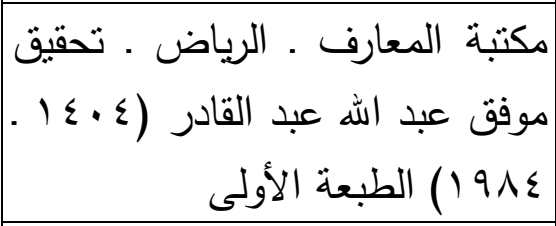 & |السهمي بن بوسف & لسؤالات \\
\hline مؤسسة الرسالة . . الطبعة الثالثة & الدافظ الذهب ش شمس & ير أعلام النبلاء \\
\hline 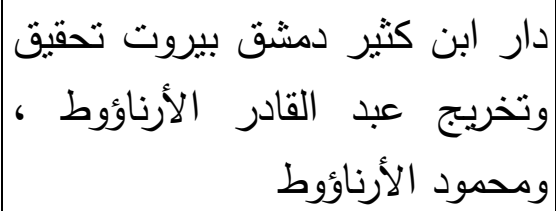 & الحنبل $\quad$ العماد & خبار من ذهب الذهب في \\
\hline
\end{tabular}




\begin{tabular}{|c|c|c|}
\hline الطبعة & المؤلف & اسم الكتاب \\
\hline مؤسسة الرسالة ـ شعيب الأرناؤوط & |أبو & شرح مشكل الآثار \\
\hline دار الأرقم لبنان & ملا علي القاري & شرح نخبة الفكر \\
\hline 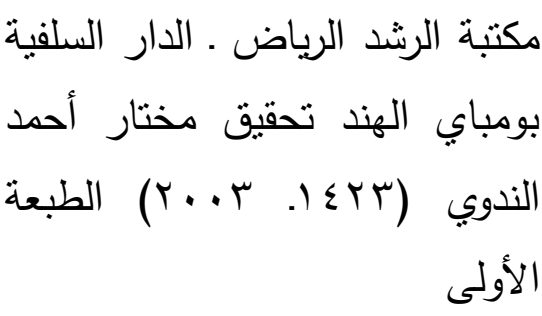 & |أبو بكر البيهقي & 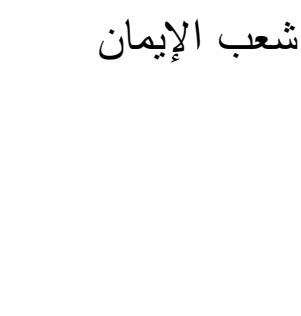 \\
\hline دمد إحياء التراث العربي · تحقيق & 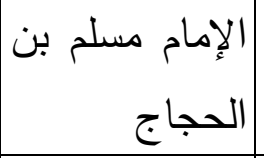 & صحيح مسلم \\
\hline 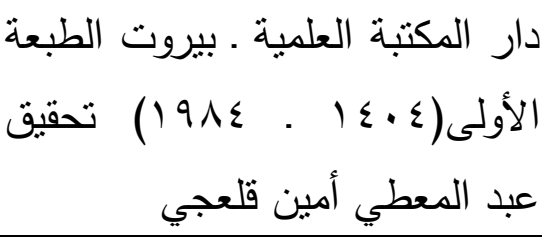 & |أبو & للضعقيلي \\
\hline 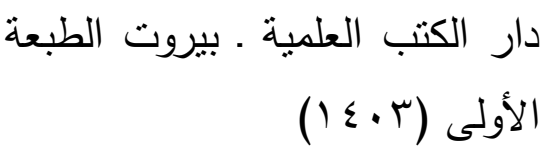 & الحافظ جلال & طبقات الحفاظ \\
\hline 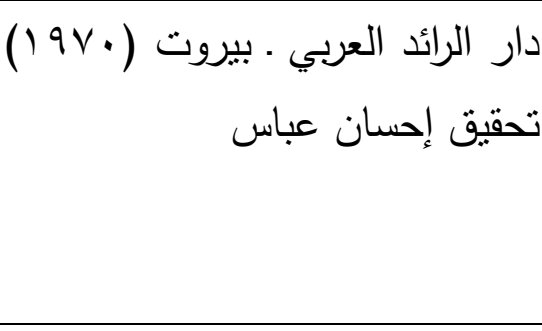 & 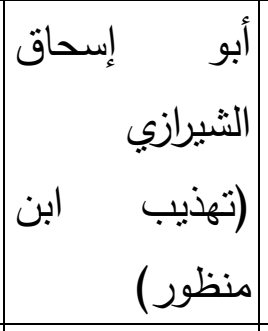 & طبقات الفقهاء \\
\hline دار صادر بيروت ـ تحقيق إحسان & |محمد بن سعد & الطبقات الكبرى \\
\hline
\end{tabular}


نظرة منيفة إلى المكانة الحليثية للإمام الأعظم أبي حنيفة

\begin{tabular}{|c|c|c|}
\hline الطبعة & المؤلف & سم الكتاب \\
\hline دار الفكر ـ تحقيق سهيل زكار & خليفة بن خياط & خبقات خليفة بن \\
\hline دار الكتب العلمية ـ بيروت لبنان & القاضي & عارضة الأحوذي \\
\hline تحقيق ودراسة مولوي محمد ملا & الصمد & 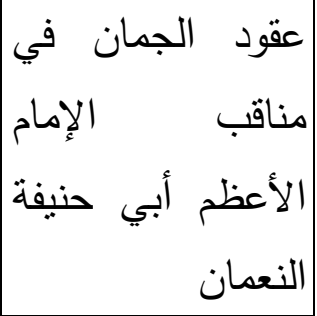 \\
\hline آنشر إدارة العلوم الأثربة، فيصل & الحافظ الفوزي & لعلل المتتاهية \\
\hline 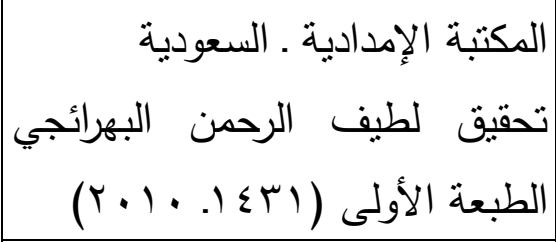 & أبو & وأخباره ومناقبيه أبي حنيفة \\
\hline المكنبة الأزهربة للتراث & الإلمام & وحقيثه أهل العراق \\
\hline 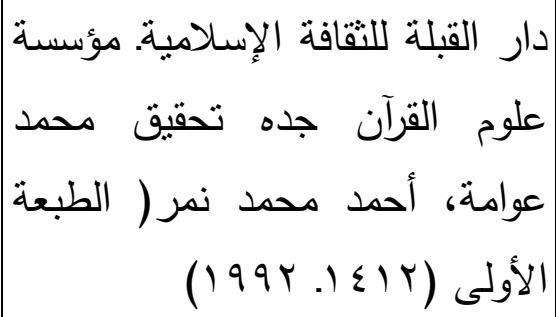 & الحافظ الدمس & الكاشف في معرفة له رواية في \\
\hline
\end{tabular}




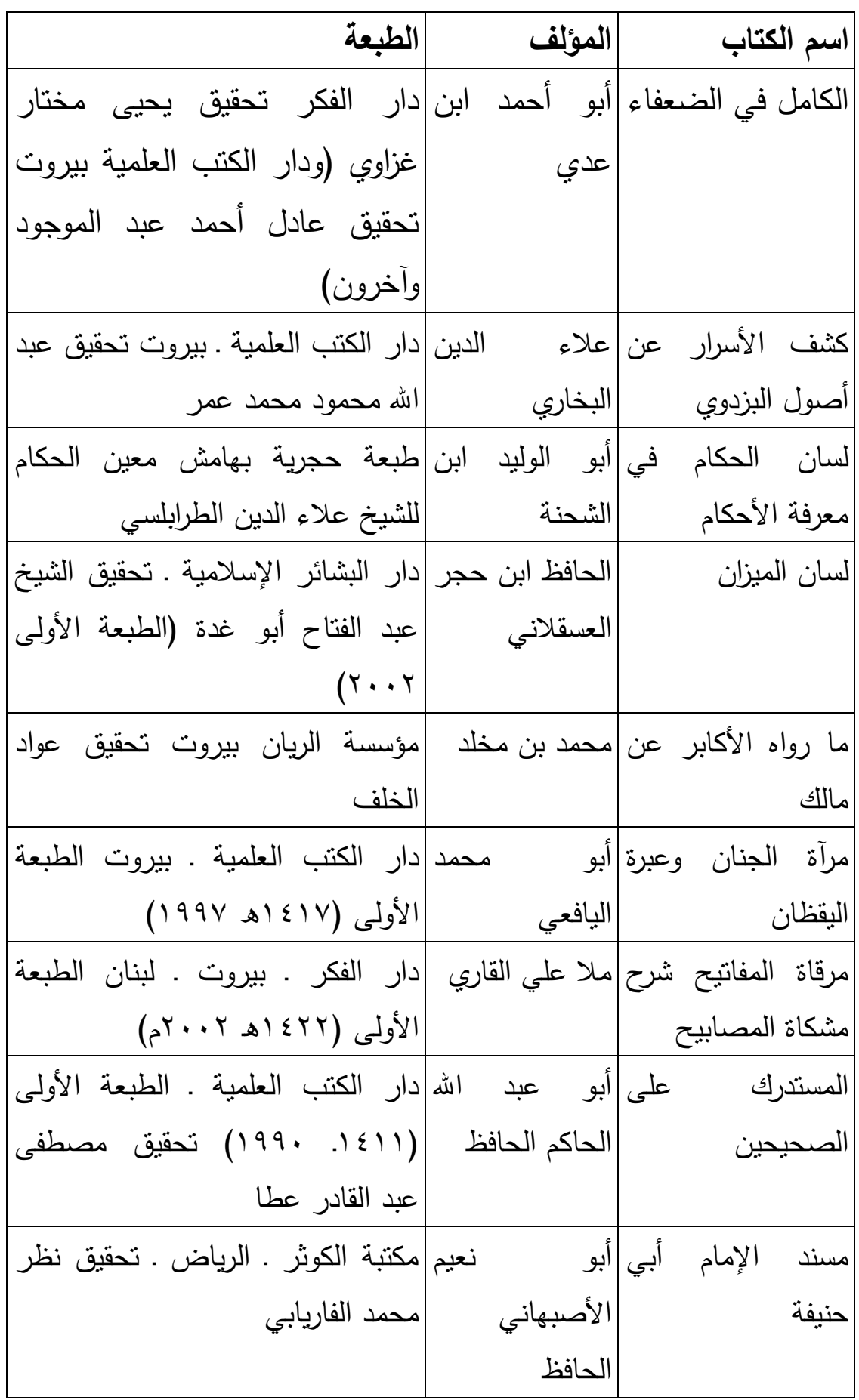


نظرة منيفة إلى المكانة الحديثية للإمام الأعظم أبي حنيفة

\begin{tabular}{|c|c|c|}
\hline الطبعة & المؤلف & م الكتاب \\
\hline 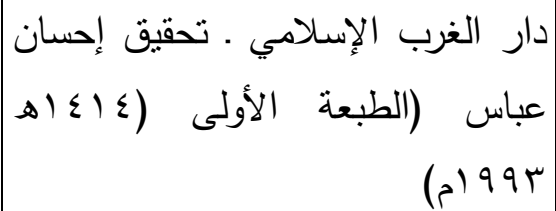 & شاقوت الحموي & لأدباه \\
\hline مكتبة الدار المدينة المنورة الطبعة & أحمد بن اله العجلي & ل لثقات \\
\hline 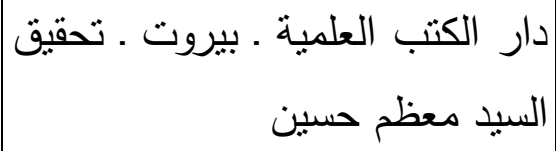 & أبو & علوم \\
\hline تحقيق محمد حسن محمد إسماعيل العلية ـ بيروت لبنان & أبو محمد بدر & 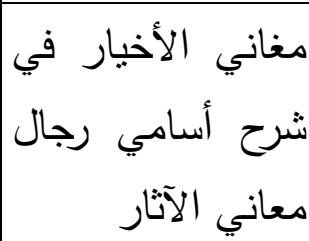 \\
\hline دحمد عثمان الكتاب العربي بيروت تحقيق & الشخس & مقاصد الحسنة \\
\hline 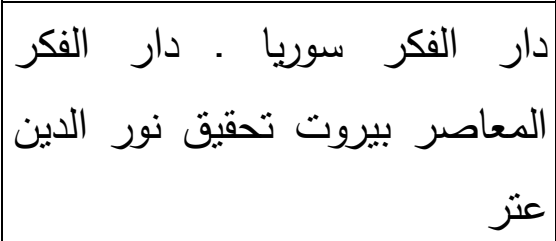 & 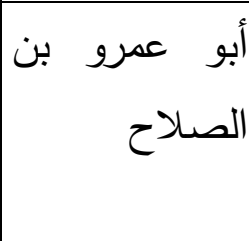 & قدمة ابن الصـلاح \\
\hline تحقيق الثبن الثبوعات الإسلامية بحلب & العبلامة النعمداني & حنيفة في الحديث الإمام أبي \\
\hline مكتبة الملك فهر الوطنية ـ تحقيق & أبو زكريا يحيى & لأزبعة \\
\hline
\end{tabular}




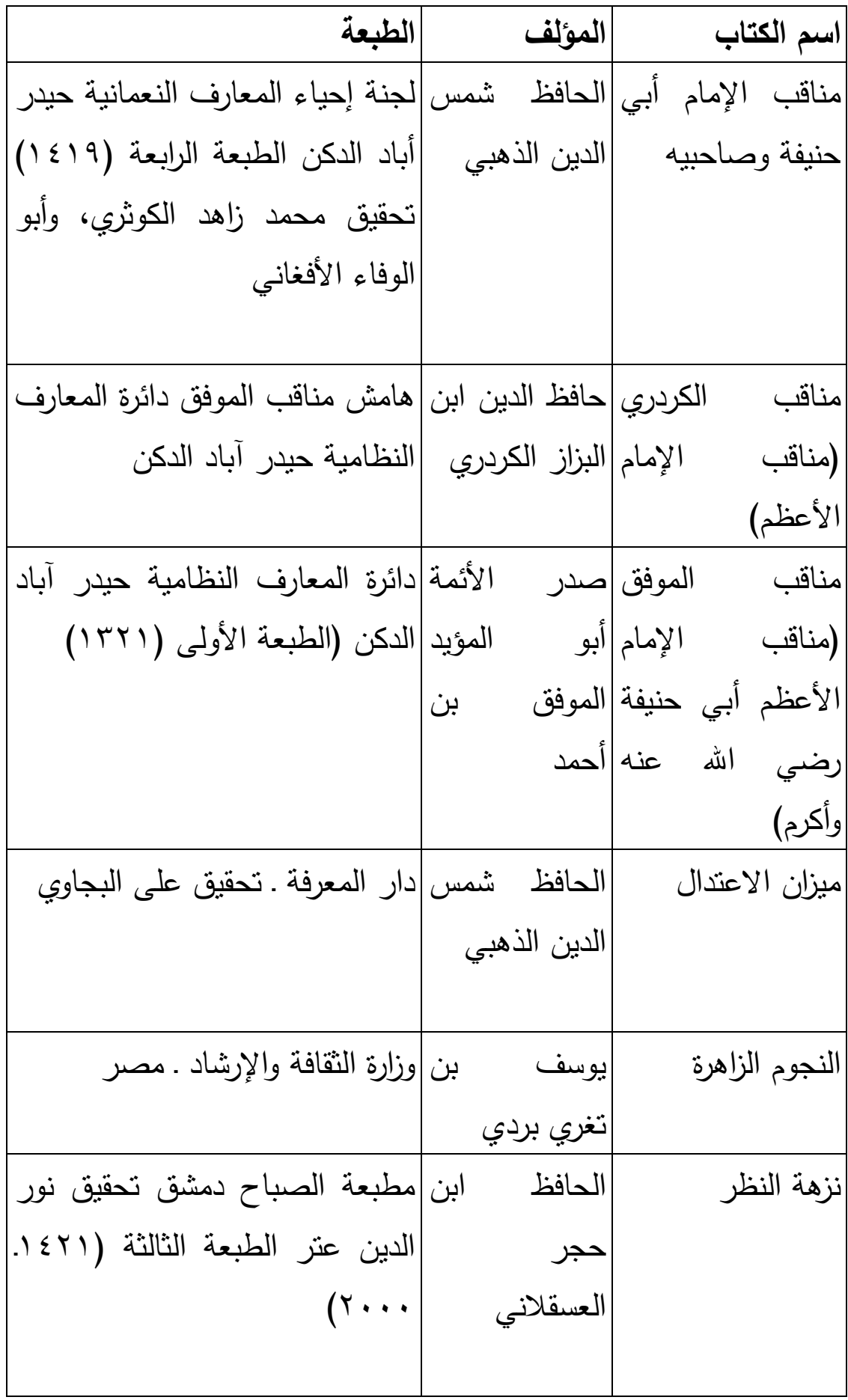


نظرة منيفة إلى المكانة الحديثية للإمام الأعظم أبي حنيفة

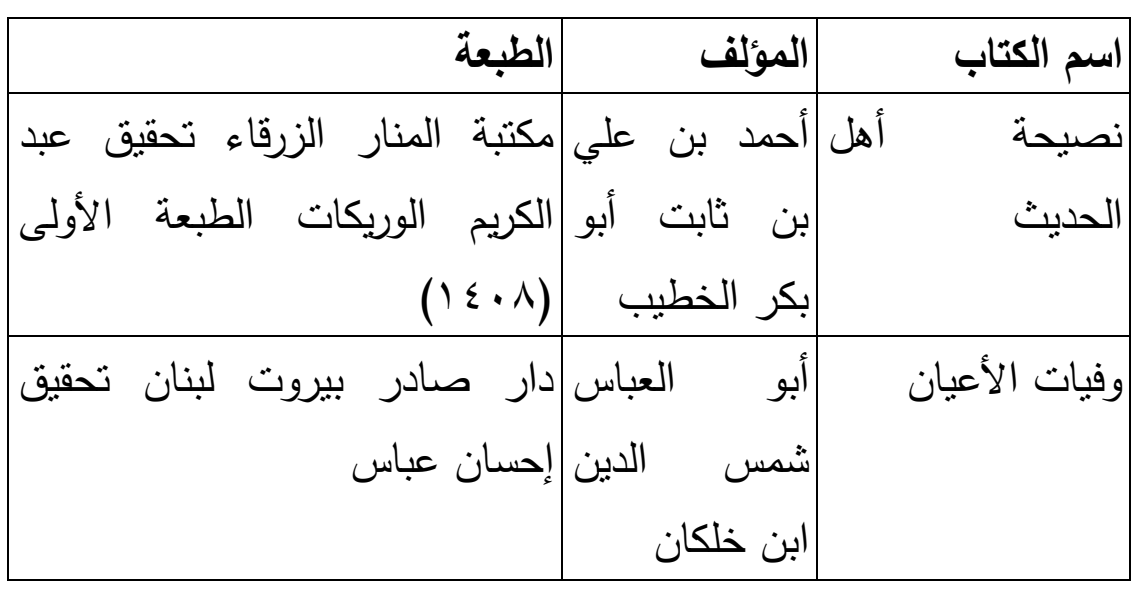

rrq 
